Bulletin of the Natural History Museum, 2020, 13: 87-169.

Received 30 Oct 2020; Accepted 11 Nov 2020.

doi:10.5937/bnhmb2013087N

UDC: $581.9(497.11)$

Original scientific paper

\title{
MATERIAL ON THE ANNOTATED CHECKLIST OF VASCULAR FLORA OF SERBIA. NOMENCLATURAL, TAXONOMIC AND FLORISTIC NOTES II
}

\author{
MARJAN NiKETIĆ ${ }^{1 *}$, GORDANA TOMOVIĆ ${ }^{2}$, GORAN ANAČKOV ${ }^{3}$, MIRJANA
} BARTULA ${ }^{4}$, SLADJANA DJORDJEVIĆ ${ }^{5}$, VLADAN DJORDJEVIĆ ${ }^{2}$, SUZANA DJORDJEVIĆ-MILOŠEVIĆ ${ }^{6}$, ŠEMIJA DURAKI ${ }^{7}$, MILAN GAVRILOVIĆ ${ }^{2}$, PEDJA JANAĆKOVIĆ ${ }^{2}$, EVA KABAS̆ ${ }^{2}$, NEVENA KUZMANOVIĆ ${ }^{2}$, DMITAR LAKUŠIĆ ${ }^{2}$, PREDRAG LAZAREVIĆ ${ }^{2}$, RANKO PERIĆ ${ }^{8}$, VLADIMIR RANDJELOVIĆ ${ }^{9}$, DRAGIŠA SAVIĆ ${ }^{10}$, MIHAJLO STANKOVIĆ ${ }^{11}$, IVANA STEVANOSKI ${ }^{2}$, VERICA STOJANOVIĆ $^{12}$, OLGA VASIĆ ${ }^{1}$, SNEŽANA VUKOJIČIĆ ${ }^{2}$, BOJAN ZLATKOVIĆ ${ }^{9}$, VLADIMIR STEVANOVIĆ ${ }^{13}$

${ }^{1}$ Natural History Museum, Njegoševa 51, 11000 Belgrade, Serbia, e-mail: mniketic@nhmbeo.rs, oljav27@gmail.com

${ }^{2}$ Institute of Botany and Botanical Garden, Faculty of Biology, University of Belgrade, Serbia, e-mail: gtomovic@bio.bg.ac.rs

${ }^{3}$ Department of Biology and Ecology, Faculty of Sciences, University of Novi Sad, Serbia, e-mail: goran.anackov@dbe.uns.ac.rs

${ }^{4}$ Faculty of Applied Ecology Futura, Metropolitan University, Serbia

${ }^{5}$ Faculty of Agriculture, University of Belgrade, Serbia

${ }^{6}$ Singidunum University, Serbia

${ }^{7}$ Eight Belgrade Grammar School, Grčića Milenka 71, 11000 Belgrade, Serbia

${ }^{8}$ Institute for Nature Conservation of Vojvodina province, Novi Sad, Serbia, e-mail: ranko.peric@pzzp.rs

${ }^{9}$ Department of Biology and Ecology, Faculty of Natural Sciences and Mathematics, University of Niš, Serbia, e-mail: vladar@pmf.ni.ac.rs, bojanzlat@pmf.ni.ac.rs

${ }^{10}$ National Park "Fruška Gora", Sremska Kamenica, Serbia, e-mail:dragita@gmail.com

${ }^{11}$ Nature Conservation Movement of Sremska Mitrovica, Serbia, e-mail: trogloxen@gmail.com

${ }^{12}$ Institute for Nature Conservation of Serbia, Belgrade, Serbia, e-mail: verica.stojanovic@zzps.rs

${ }^{13}$ Serbian Academy of Sciences and Arts, Belgrade, Serbia, e-mail: vstev@bio.bg.ac.rs

The paper propose nine new nomenclature combinations and indicate eight new synonyms. There are 12 taxa (species and subspecies) of vascular flora which are new for the flora of Serbia (of which nine are autochthonous and three 
allochtonous plants). An old or unreliable literature records for three autochthonous and one allochthonous plant in the flora of Serbia has been confirmed. Eight plant taxa are a novelty for proper Serbia, Vojvodina, or Kosovo and Metohija, and for three plants, presence in certain administrative units in Serbia has been proved. The last part of the paper contains information on eight taxa whose presence in Serbia or in its territorial units has been refuted.

Key words: vascular flora, checklist, nomenclature, taxonomy, Serbia

\section{INTRODUCTION}

This paper represents a continuation of the inventory of the flora of Serbia through intensive field research, identification and revision of specimens from herbarium collections, as well as a comprehensive review of extensive taxonomic, floristic and phytocoenological literature. The first such article was published two years ago (Niketić et al. 2018a) as a preparation for the publication of An annotated checklist of vascular flora of Serbia 1 (Niketić \& Tomović 2018). In that paper, new data on taxa were integrated, which included the following groups: Lycopodiopsida, Polypodiopsida, Gnetopsida, Pinopsida and Liliopsida.

In the meantime, a number of floristic and chorological contributions have been published (Bogosavljević \& Zlatković 2018, Duraki \& Niketić 2018a,b,c,d, Jovanović et al. 2018, Lazarević \& Zlatković 2018, Radak et al. 2019, Süveges et al. 2019, Zlatković \& Bogosavljević 2020, Sabovljević et al. 2020; Tomović et al. 2020), as well as taxonomic (Novaković et al. 2018) and phylogeographic ones (Janković et al. 2019) related to plant taxa from Serbia, which also contributed to better knowledge of the presence and distribution of native and adventive flora in our country.

The second paper presents nomenclatural, taxonomic and floristic notes related to taxa from the Magnoliopsida group, as well as some novelties that have not been published in the An annotated checklist of vascular flora of Serbia 1 (Niketić \& Tomović 2018) because in the meantime some significant findings for the flora of Serbia or certain administrative units have emerged.

\section{MATERIAL AND METHODS}

In order to accomplish all the floristic and distribution data we performed intensive field investigation, identification and revision of herbarium material as well as checked numerous literature sources. Collected plant specimens are stored in the Herbarium of the Natural 
History Museum in Belgrade (BEO), Herbarium of the Institute of Botany and Botanical Garden "Jevremovac", University of Belgrade (BEOU), the Herbarium of Department of Biology and Ecology, Faculty of Sciences, University of Novi Sad (BUNS), the Herbarium of the Institute for Nature Conservation of the Vojvodina province (PZZP) (Thiers 2021) and Herbarium of the Faculty of Sciences and Mathematics, Department of Biology and Ecology, University of Niš (HMN).

The names and classification of families and affinity of genera to certain families were presented in accordance with APG IV (2016) for angiosperm families (flowering plants), with certain deviations in the taxa of the highest rank. The nomenclature is harmonized with modern taxonomic studies for particular groups and new taxonomic and/or nomenclature solutions were also presented. Families, genera and species were listed in the alphabetical order of their Latin names. Short taxon description for newly registered taxa for Serbia is accomplished by using numerous botanical literature, with minor modifications and changes which are the result of herbarium specimens inspections and field observations.

In the nomenclature lists heterotypic and homotypic names are sorted chronologically. Nomenclatural provisions are applied from ICN (Turland et al. 2018).

Invasiveness status was determined using the terminology according to Niketić \& Tomović (2008).

Distribution of the studied taxa within the territory of the Republic of Serbia was presented and mapped according to the grid map with squares of $10 \times 10 \mathrm{~km}$, based on the Military Grid Reference System (MGRS) projection (Lampinen 2001).

\section{RESULTS AND DISCUSSION}

\section{Nomenclatural notes}

\section{LILIOPSIDA}

IRIDACEAE

Crocus tommasinianus Herb., J. Hort. Soc. London 2: 273 (1847).

= C. pancicii Janka, Oesterr. Bot. Z. 18: 57 (1868), p.p.?, syn. nov.

= Crocus heuffelianus var. csapodyae Horvát \& Jáv. in Jáv., Bot. Közlem. 51(4): 180 (1964).

- C. serbicus A. Kern. ex Maw, Gard. Chron., n.s. 16: 368 (1881), nom. inval. (pro syn. of C. tommasinianus Herb.).

- "C. minimus" sensu Pančić, Verh. K.K. Zool.-Bot. Ges. Wien 6: 578 (1856) [non DC. Redouté, Liliac. 2: 81 (1804)]. 
In this article, the type of $C$. pancicii Janka was included in $C$. tommasinianus Herb. The first description and diagnosis of Janka's plant were presented by Pančić (1856) under the name "C. minimus DC." (from C. biflorus group) and it was recorded for the surroundings of Jagodina (Sugudbina village) in Šumadija region of Serbia. The geographical position of the locality was interpreted as $20 \mathrm{~km}$ west of Jagodina in Niketić et al. (2018b), referring to the village of Velika Sugudbina. However, Pančić $(1874,1884)$ specified that the locality is between the village Oparić and [Mala] Sugudbina, which is $25 \mathrm{~km}$ south of Velika Sugudbina, closer to Trstenik than Jagodina. Pančić claimed that this plant could be a new species to science, from the $C$. vernus group, and he did not bring it into connection with representatives of the $C$. biflorus group. Even earlier, based on Pančić's original description of "C. minimus DC." Janka (1868) described $C$. pancicii and mentions it also for Karlovo in $\mathrm{C}$ Bulgaria. Although so far the original Pančić's material has not been found, nor has any Crocus species been found at Pančić's locality, numerous populations of $C$. tommasinianus have been observed only $8 \mathrm{~km}$ southeast, between villages Lazarevac and Konjuh. Having in mind the dominant presence of this species in a wider area, it can be concluded that the name C. pancicii actually corresponds to C. tommasinianus.

\section{Collected specimen:}

C Serbia, Kruševac, Lazarevac village, 211 m, 21.163889 E, 43.656389 N, MGRS 34T EP13, coll. V. Randjelović, J. Stojanović 08-Mar-2019, det. V. Randjelović (HMN 13911).

V. Randjelović, M. Niketić

\section{MAGNOLIOPSIDA}

ASTERACEAE (COMPOSITAE)

Amphoricarpos neumayerianus subsp. autariatus (Blečić \& Mayer) Niketić, Gavrilović \& Janaćković, comb. nov.

$\equiv$ Amphoricarpos autariatus Blečić \& E. Mayer [subsp. autariatus], Phyton (Horn) 12: 155 (1967) [basionym].

= Amphoricarpos autariatus subsp. bertisceus Blečić \& E. Mayer, Phyton (Horn) 12: 156 (1967), syn. nov.

- A. neumayeri var. intermedia Fukarek, Glasn. Zemaljsk. Muz. Bosne Hercegovine Sarajevu. Prir. Nauke 3-4: 161 (1965), nom. inval. (nom. nud.). 
Amphoricarpos neumayerianus subsp. murbeckii (Bošnjak) Niketić, Gavrilović \& Janaćković, comb. nov.

$\equiv$ Amphoricarpos neumayeri subsp. murbeckii Bošnjak, Glasn. Hrvatsk. Prir. Društva 41-48: 62 (1936) [basionym] $\equiv$ A. neumayeri var. murbeckii (Bošnjak) Fukarek, Glasn. Zemaljsk. Muz. Bosne Hercegovine Sarajevu. Prir. Nauke 3-4: 161 (1965), comb. inval.

= Amphoricarpos neumayeri var. velezensis Murbeck, Acta Univ. Lund. 27: 100 (1892).

= A. neumayeri f. latifolius Beck, Jahreskat. Wiener bot. Tauschverein: 20 (1894).

In the traditional botanical literature sources, one or two species of the relict orophytic genus Amphoricarpos Vis. are most often mentioned for the Balkan Peninsula. In two species concept (Blečić \& Mayer 1967, Greuter 2006+) the type species of the genus, A. neumayerianus (Vis.) Greuter, was mainly known from SW oromediterranean Montenegro (Mt Orjen and Mt Lovćen) including the bordering part of Herzegovina. Previously long-used invalid name, A. neumayeri Vis., has been replaced by Greuter (2003). The second 'species', A. autariatus Blečić \& E. Mayer, was mentioned for a wider area of the western Balkans, from Bosnia and Herzegovina to NW Greece, including two subspecies: autariatus (incl. A. neumayeri subsp. murbeckii Bošnjak) and bertisceus Blečić \& E. Mayer. In a single species concept (Webb 1976, Tan 1991) there were two subspecies: "neumayeri" and murbeckii (described from Herzegovina, but by its distribution equivalent to the then known $A$. autariatus). In the recent comprehensive molecular and morphometric study of the representative populations of the genus, Caković et al. (2015) has shown that all of these taxa can be considered conspecific and without intraspecific taxa.

However, we believe that some obvious differences should not be overlooked and that at least three subspecies can be identified within a common species, A. neumayerianus. This primarily refers to a clear genetic split (ITS, AFLP) between the northwestern (from mountains around the Neretva river in Herzegovina and Mt Vlašić in Bosnia) and other populations. Herzegovinian plants were previously included within subsp. murbeckii (Bošnjak 1936, Webb 1976, Tan 1991), but with an illegitime specific epithet (Art. 52.1) which was corrected on this occasion. The subspecies murbeckii is characterized by denser indumentum and fewer and smaller cauline leaves. The rest of the species range includes the type subspecies present in Mt Orjen, Mt Lovćen and Mt Njegoš, and subsp. autariatus (Blečić \& Mayer) Niketić, Gavrilović \& Janaćković that occupies the largest part of the species distribution area (including SW Serbia). The type subspecies (neumayerianus) was broadly accepted taxon (at different ranks) in all traditional classifications. It has relatively narrow 
leaves, more acute phyllaries and winged cypselae. It is also separated genetically (AFLP and partially in plastid data) and morphologically (PCA, DCA) in Caković et al. (2015). Transitional populations (Mt Maganik, Mt Sinjavina, Mt Žijevo, Mt Komovi) were observed in the overlapping zone by Fukarek (1965) (var. intermedia, nom. nud.) and also confirmed genetically (Caković et al. 2015) (AFLP). In this study not enough diagnostic characters were observed for "subsp. bertisceus" and therefore it was included in subsp. autariatus. Southeastern population from S Albania and NW Greece are also genetically isolated (Caković et al. 2015), but due to insufficient evidence, their status remained unresolved. Consequently, proposed classification recognizes three subspecies and it is basically similar to that proposed by Webb (1976) and Tan (1991), except the separation of subsp. murbeckii and subsp. autariatus.

Recent morphometric and molecular analyzes (Gavrilović 2019) and metabolomic study (Cvetković et al. 2018) of the Balkan representatives of the genus Amphoricarpos also confirmed our taxonomic treatment. According to Cvetković et al. (2018) guaianolide sesquiterpene lactones (amphoricarpolides), as reliable chemotaxonomic markers, most contribute to differences between taxa neumayerianus ["neumayeri"] and autariatus while the compounds that contributed to the differences between "subsp. autariatus" and "subsp. bertisceus" "do not have chemotaxonomic significance".

M. Niketić, M. Gavrilović, P. Janaćković

Hieracium brachytrichophyes (O. Behr, E. Behr \& Zahn) Niketić, comb. et stat. nov.

$\equiv$ Hieracium sparsum subsp. brachytrichophyes O. Behr, E. Behr \& Zahn, Glasnik Skopskog Naučnog Društva 20, Sect. Sci. Nat. 7: 34 (1939) [basionym].

IND. LOC.: "Korab: Hänge an der Waldgrenze an der Dlaboka ["Luboka"] Reka, ca. 1600-1700 m". LECTOTYPE (here designated): "Macedonia, in montibus Korabensibus, ad declives praeter Dlaboka ["Luboka"] reka prope finem si[1]varum, ca. 1600 m.”, 23-Jul-1937, E. Behr (987 S 13-19905 [photo!] image available at https://plants.jstor.org/ stable/ viewer/10.5555/al.ap.specimen.s12-19905); isolectotype: M.

Until recently, this plant was considered very rare and only recorded for Mt Korab in W North Macedonia (Behr et al. 1939a). A few years ago Duraki \& Niketić (2018a) discovered many populations on Šar Planina Mts on the border of North Macedonia and Serbia (Metohija and Kosovo). The taxon belongs to Alpine-Carpatho-Balkanic-W Asian complex $\mathrm{H}$. djimilense (prenanthoides-sparsum) which includes 17 taxa (Greuter 2006+). 
Since it can be assumed that sympatric H. oroglaucum O. Behr, E. Behr \& Zahn [H. naegelianum > pseudobifidum (transylvanicum-bifidum)] is also included in its genealogy, $H$. brachytrichophyes could be considered as a microspecies.

M. Niketić

Hieracium cernyanum (Hayek \& Zahn) Niketić, comb. et stat. nov.

$\equiv$ Hieracium gaudryi subsp. cernyanum Hayek \& Zahn in Engl., Pflanzenr. 76: 570 (1921) [basionym].

IND. LOC.: "Felshänge des Gipfelregion des Koritnik (Doerfler, It. Alb. n. 966)!". LECTOTYPE (here designated): [Serbian-Albanian border] "Distrikt Luma, Felsigen Hänge in der Gipfelregion des Koritnik, ca. 2200 m", 6-Aug-1918, I. Dörfler (sub H. pannosum subsp. Zernyanum) (966 B barcode 109004796 [photo!] image available at https://api.gbif. org/v1 /image/unsafe/https\%3A\%2F\%2Fpictures.bgbm.org\%2Fdigilib\%2FScal er\%2FIIIF\%2FB!10!90!04!79!B_10_9004796.jpg\%2Ffull\%2F2048\%2C $\% 2 \mathrm{~F} 0 \% 2 \mathrm{Fdefault} . j p g$ ); isolectotypes: $\mathrm{S}, \mathrm{LD}$.

= Hieracium pannosum subsp. doerflerianum Hayek \& Zahn in Engl., Pflanzenr. 76: 563 (1921), syn. nov.

IND. LOC.: "Felsen des Gipfel des Koritnik ["Koritnica"] (Doerfler, It. Alb. n. 965 pp.)!". LECTOTYPE (here designated): [Serbian-Albanian border] "Distrikt Luma, Felsigen Hänge in der Gipfelregion des Koritnik, ca. 2200 m", 6-Aug-1918, I. Dörfler (sub H. pannosum subsp. murbeckianum) (965 LD barcode 1731091 [photo!] image available at https:// plants.jstor.org/stable/viewer/10.5555/al.ap.specimen.ld1731091); isolectotypes: B, S.

= Hieracium pannosum [subsp. doerflerianum] var. pantocsekianum Hayek \& Zahn in Engl., Pflanzenr. 76: 563 (1921), syn. nov.

IND. LOC.: "Mit the Unterart (Doerfler 1. c. n. 965 pp.)!". LECTOTYPE (here designated): [Serbian-Albanian border] "Distrikt Luma, Felsigen Hänge in der Gipfelregion des Koritnik, ca. 2200 m", 6-Aug-1918, I. Dörfler (sub H. pannosum subsp. doerflerianum) (965 B barcode 10 0715361 [photo!] image available at https://api.gbif.org/v1/image/unsafe/ https\%3A\%2F\%2Fpictures.bgbm.org\%2Fdigilib\%2FScaler\%2FIIIF\%2F B!10!07!15!36!B_10_0715361.jpg\%2Ffull\%2F2048\%2C\%2F0\%2Fdefa ult.jpg).

So far, the only confirmed locality of the taxon is in Mt Koritnik on the border of Serbia (Metohija) and Albania. It was originally included in Greek H. gaudryi Boiss. \& Orph. with proposed hybridogenous origin $H$. gymnocephalum < pannosum (Zahn 1921). Based on morphology and 
distribution of other Hieracium species in the environment, the new proposed combination $H$. pannosum s.l. - scardicum (pannosum s.l. $>$ naegelianum) and specific rank would be much more appropriate. The characteristic dark hairs at the base of the involucre are somewhat noticeable and are probably inherited from $H$. naegelianum Pančić. The specific rank of $H$. cernyanum and its exclusion from $H$. gaudryi were indirectly pointed out by Buttler (1991), who considered $H$. gaudryi to be endemic to Greece: "Plants referred to the species by Zahn $(1921,1936)$ under different subspecific and varietal names do not belong here". Hieracium cernyanum also includes forms with denser indumentum, described as Hieracium pannosum subsp. doerflerianum Hayek \& Zahn and var. pantocsekianum Hayek \& Zahn, from the same locality (Zahn 1921). The connection of these plants with $H$. cernyanum was also emphasized in the protologue of subsp. doerflerianum ("inter Cernyanum and pannosum"), enabling inclusion of subsp. doerflerianum and var. pantocsekianum in $H$. cernyanum on this occasion. Plants with varietal name were also recorded for N Albania (Mnela) (Zahn 1936). Closely related species to $H$. cernyanum is $H$. trikalense Buttler from Pindus Mts in Greece.

M. Niketić

Hieracium delpinoi Bald., Malpighia 5: 76 (1891) [“H. delpinii”].

$\equiv$ Hieracium waldsteinii subsp. delpinoi (Bald.) Zahn in Rchb., Icon. Fl. Germ. Helv. 19(2): 112 (1907).

IND. LOC.: "In rupestribus travertinaceis ad coenobium Moracae". LECTOTYPE (here designated): [Montenegro] "In rupestribus travertinaceis ad coenobium Moracae", Aug-1890, A. Baldacii ["H. delpinii"] (E barcode 00413068 [photo!] image available at https://plants.jstor.org/ stable/viewer/10.5555/al.ap.specimen.m0161496).

= Hieracium waldsteinii subsp. nipholeucum Zahn in Rchb., Icon. Fl. Germ. Helv. 19(2): 109 (1907), syn. nov.

IND. LOC.: "Albanien:...Klementi...Baldacii...VIII...155.”. LECTOTYPE (here designated): [Albania] "In saxosis fl. Cem ad Selce distr. Klementi”, 09-Aug-1901, A. Baldacii (sub H. delpinoi) (155 P barcode 02806108 [photo!] image available at https://api.gbif.org/v1/image/ unsafe/http\%3A\%2F\%2Fmediaphoto.mnhn.fr\%2Fmedia\%2F144134467 8661sdUV3G6moFz71va0).

A comparison of the type material of Hieracium delpinoi Bald. (E 00413068) and H. waldsteinii subsp. nipholeucum Zahn (P 02806108) showed their great similarity. In addition, there are numerous records in which these two names are listed for the same localities. Zahn $(1921,1936)$ 
included both taxa within $H$. waldsteinii Tausch as separate subspecies within separate groups (plumulosum and suborieni), but he nevertheless pointed out their similarity. These two morphotypes differ slightly in the density of the indumentum, but this character is very variable. Hieracium delpinoi was recorded for Montenegro, Albania, Serbia (Metohija) and NW Greece. Further studies will show whether it needs to be combined with some other taxa from the $H$. waldsteinii complex.

\section{Niketić}

Hieracium hayekianum (Dörfl. \& Zahn) Niketić, comb. et stat. nov.

$\equiv$ Hieracium gaudryi subsp. hayekianum Dörfl. \& Zahn in Engl., Pflanzenr. 76: 570 (1921) [basionym].

IND. LOC.: "Gipfelregion des Paštrik (Doerfler, It. Alb. n. 877)!". LECTOTYPE (here designated): [Serbian-Albanian border] "Distrikt Hasi, an felsen des Gipfelregion des Paštrik, ca. 1700 m", 27-Jul-1918, I. Dörfler (B barcode 109004793 [photo!] image available at https://api. gbif.org/v1/image/unsafe/https\%3A\%2F\%2Fpictures.bgbm.org\%2Fdigili b\%2FScaler\%2FIIIF\%2FB!10!90!04!79!B_10_9004793.jpg\%2Ffull\%2F 2048\%2C\%2F0\%2Fdefault.jpg).

This taxon is only known from the border of Serbia (Metohija) and Albania (Mt Paštrik) (Zahn 1921, 1936). The reasons for exclusion from $H$. gaudryi are similar to those for $H$. cernyanum (see on page 93). Although it probably has a similar origin [H. pannosum s.l. - scardicum (pannosum s.l. $>$ naegelianum)] and morphology as $H$. cernyanum, it has more elongated and acute leaves, which indicates a slightly increased resemblance to $H$. naegelianum.

M. Niketić

Hieracium oroglaucum O. Behr, E. Behr \& Zahn, Glasnik Skopskog Naučnog Društva 18, Sect. Sci. Nat. 6: 66 (1937).

= Hieracium sparsum subsp. livadicanum O. Behr, E. Behr \& Zahn, Glasnik Skopskog Naučnog Društva 20, Sect. Sci. Nat. 7: 128 (1939), syn. nov.

IND. LOC.: "Felsen am Abhang der Livadica, ca. 1800-1900 m". LECTOTYPE (here designated): "Macedonia: in saxis clivium Livadicae, in montibus Šarplaninae sitae, ca. 1800-1900 m.", 23-Jul-1938, E. Behr (1178 M barcode 0165172 [photo!] image available at https:// plants.jstor.org/stable/viewer/10.5555/al.ap.specimen.m0165172).

This species was previously known only from Mt Korab in W North Macedonia (Behr et al. 1937, 1939a) and recently found in several localities in E Montenegro, SW North Macedonia, SW Serbia (Kosovo and Metohija) and SE Serbia (Duraki \& Niketić 2018b). The authors of this 
polymorphic species interpreted its origin as " $H$. naegelianum $>$ pseudobifidum (transylvanicum-bifidum)" (Behr et al. 1937). Later, the same authors also described $H$. sparsum subsp. livadicanum O. Behr, E. Behr \& Zahn from the border of North Macedonia and Kosovo in Serbia (Behr et al. 1939b). According to them it is similar to H. sparsum subsp. pilosifrons Zahn from E Serbia. However, it is clearly noticeable on the type material (M 0165172) that the morphology of the involucre generally corresponds to the ' $H$. naegelianum type' and that these specimens actually correspond to H. oroglaucum O. Behr, E. Behr \& Zahn.

M. Niketić

Hieracium platytrigonodon (O. Behr, E. Behr \& Zahn) Niketić, comb. et stat. nov.

$\equiv$ Hieracium bohatschianum subsp. platytrigonodon O. Behr, E. Behr \& Zahn, Glasnik Skopskog Naučnog Društva 18, Sect. Sci. Nat. 6: 65 (1937) [basionym].

IND. LOC.: "Korab: Hänge an der Waldgrenze an der Dlaboka ["Luboka"] Reka, ca. 1600-1700 m". LECTOTYPE (here designated): "Macedonia: in montibus Korabensibus, in fageto ad stanicam Stalna patrola Gabrova dictam, ca. 1780 m.", 24-Jul-1937, E. Behr (975 M barcode 0161409 [photo!] image available at https://plants.jstor.org/ stable/viewer/ 10.5555/al.ap.specimen.m0161409).

This taxon is only known from two localities: Mt Korab in W North Macedonia (Behr et al. 1937) and Crni Vrh peak on Šar Planina Mts in Serbia (Metohija) (Duraki \& Niketić 2018c). It belongs to CarpathoBalkanic complex H. bohatschianum (schmidtii-sparsum) which includes several taxa. Due to its elongated basal and reduced cauline leaves it could be considered as a microspecies probably originated from sympatric Hieracium schmidtii subsp. balkanum (R. Uechtr. ex Pančić) Niketić.

M. Niketić

Hieracium squarrosobracchiatum (O. Behr, E. Behr \& Zahn) Niketić, comb. et stat. nov.

$\equiv$ Hieracium sparsum subsp. squarrosobracchiatum O. Behr, E. Behr \& Zahn, Glasnik Skopskog Naučnog Društva 20, Sect. Sci. Nat. 7: 32 (1939) [basionym].

Previously known only from Mt Korab in W North Macedonia (Behr et al. 1939a), this very rare plant was recently discovered on Šar Planina Mts in Serbia (Metohija) (Duraki \& Niketić 2018d). Although its inclusion in $H$. sect. Cernua R. Uechtr. is not disputed, it is very different from $H$. sparsum Friv. and has to be treated as an independent microspecies. Morphologically it is much more similar to $H$. naegelianiforme $(\mathrm{O}$. Behr, E. Behr \& 
Zahn) Buttler, and according to the author of this combination (Buttler 1991) species "only superficially resembling H. sparsum". According to Behr et al. (1937) and Zahn (1938) possible origin of $H$. naegelianiforme was interpreted as "sparsum - naegelianum). The similar relations can be concluded for $H$. squarrosobracchiatum. The assumption of its hybridogenous origin is further supported by recording the triploid number of chromosomes $(2 \mathrm{n}=27)$ (Ilnicki \& Szeląg 2011).

M. Niketić

Hieracium trojanum (Zahn) Niketić, comb. et stat. nov.

$\equiv$ Hieracium pannosum subsp. trojanum O. Behr, E. Behr \& Zahn in Engl., Pflanzenr. 76: 564 (1921) [basionym].

This plant is distributed in E Serbia and E and C Bulgaria (Stara Planina, Rila and Pirin Mts) (Zahn 1936). The type specimen (BRNM 7179/36) was designated from E Serbia (Mt Basara) by Szeląg (2015). According to Zahn (1936) it belongs to H. bornmuelleri group with numerous, more conspicuous and more dentate cauline leaves. The proposed origin of this aggregate is "pannosum $>>$ racemosum" (Zahn 1936). Within aggregate $H$. bornmuelleri Freyn and $H$. cappadocicum Freyn represent the Anatolian species while $H$. friwaldii Rchb. f. is probably Cretan endemic. Hieracium mokragorae (Nägeli \& Peter) Freyn from Serbia, Montenegro, Albania and Bosnia and Hercegovina, and recently described H. crinitopannosum Szeląg \& Vladimir. from Bulgaria (Szeląg \& Vladimirov 2013), could also be included in the same group.

M. Niketić

\section{CARYOPHYLLACEAE}

Dianthus lakusicii (Wraber) Niketić, stat. et comb. nov.

$\equiv$ Dianthus nitidus subsp. lakusicii Wraber, Biol. Vestn. 36: 97 (1988) [basionym].

This endemic SE Dinaric plant, described from Mt Bjelasica in Montenegro as D. nitidus subsp. lakusicii Wraber (1988), was initially treated as Scardo-Pindic D. scardicus Wettst. (Lakušić 1966). The name is currently only disputed in POWO (2020) ["Not accepted by Govaerts (2000): World Checklist of Seed Plants Database in ACCESS D: 1-30141"] and synonymized with $D$. scardicus. Our comparison of herbarium material also confirmed essential differences between this taxon and Tatra species, $D$. nitidus Waldst. \& Kit., and similarity with geographically close $D$. scardicus. However, some morphological differences in relation to $D$. scardicus were also observed. Representatives of Dinaric populations have a higher stems, \pm acute leaves, shorter (relatively to the stem) and wider basal leaves, more numerous cauline leaves, usually acuminate epicalyx 
scales, 1-2(3) flowers in capitula and dentate petal-limb (Fig. 1). Molecular analyzes are necessary to establish definitive status and phylogenetic position of this taxon.

\section{Specimen examined:}

Montenegro, Mt Bjelasica, Lalovića dolovi above Biogradsko Lake, in pastures, 1740 m, MGRS 34T CN85, coll. M. Lovka, T. Wraber 21-Jul1987, det. T. Wraber ISOTYPE (BEO A38766) (Fig. 1B).

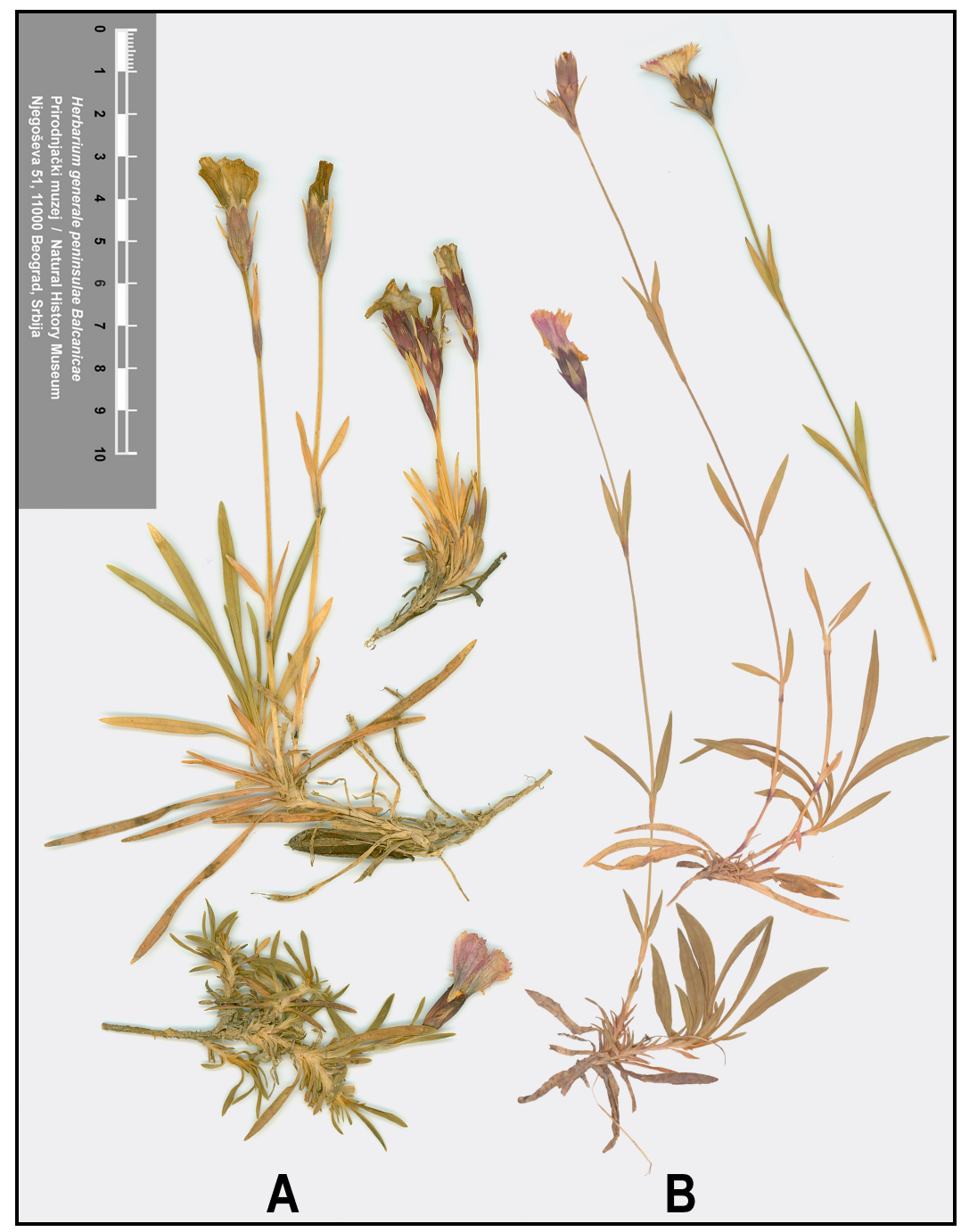

Fig. 1. - A Dianthus scardicus Wettst. from three localities on Mts Šar Planina (BEO); B isotype of D. nitidus subsp. lakusicii Wraber $[\equiv D$. lakusicii (Wraber) Niketić] (Mt Bjelasica, Lalovića Dolovi, BEO A38766). 


\section{CAPRIFOLIACEAE (DipsACACEAE)}

Knautia csikii Jáv. \& Szabó, Magyar Bot. Lapok 21: 19 (1923).

= Knautia midzorensis f. glabrescens Diklić in Josifović, F1. Srbije 5: 615 (1973), syn. nov.

The species is distributed in Prokletije and Šar Planina Mts in the Central Balkan, as well as in Mt Ozren in SW Serbia. This name is still not accepted in the current lists (Domina 2017, POWO 2020) where it is treated

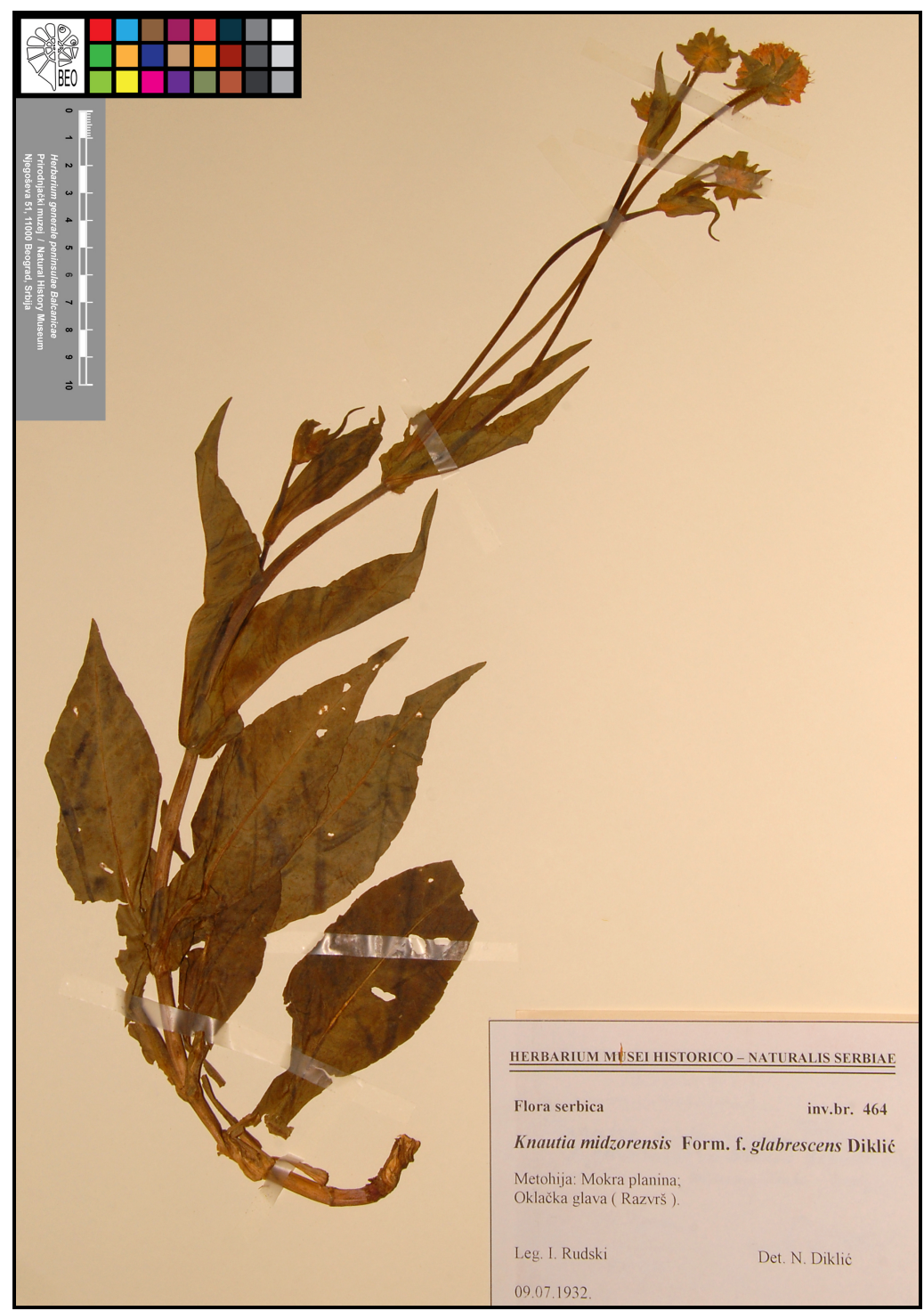

Fig. 2. - Holotype of Knautia midzorensis f. glabrescens Diklić (= K. csikii Jáv. \& Szabó) (BEO A464). 
as Alpine-Carpathian $K$. longifolia (Waldst. \& Kit.) W. D. J. Koch. However, $K$. csikii clearly differs by its relatively wider and hairy leaves which makes it closer to $K$. dinarica (Murb.) Borbás. Their phylogenetic connection was also shown in Frajman et al. (2016), with a significant distance from $K$. longifolia group. Allopatric and vicarious $K$. magnifica Boiss. \& Orph. (=K. midzorensis Formánek) occurs in the eastern and southern parts of the Central Balkans. However, Diklić (1973) described Knautia midzorensis f. glabrescens Diklić within the range of K. csikii (Mt Mokra Planina which is a part of Prokletije Mts). The analysis of the original material (BEO A464) showed that it in fact belongs to K. csikii.

\section{Specimen examined:}

Metohija, Prokletije Mts, Mt Mokra Planina, Oklačka Glava (Razvrš), MGRS 34T EN98, coll. M. Lovka, coll. I. Rudski 9-Jul-1932, det. N. Diklić HOLOTYPE (BEO A464) (Fig. 2).

M. Niketić

\section{EUPHORBIACEAE}

Euphorbia maglicensis Rohlena, Sitzungsber. Königl. Böhm. Ges. Wiss., Math.-Naturwiss. Cl. 1912(1): 111 (1913) ["Rasse der E. esula L. (= E. maglićensis m.)'].

$\equiv$ Euphorbia esula var. maglicensis (Rohlena) Hayek, Repert. Spec. Nov. Regni Veg. Beih. 30(1): 132 (1924).

IND. LOC.: "Auf dem Maglicgebirge, unter Gerölle". LECTOTYPE (here designated by D. Geltman, Oct-2000): [Montenegro] "in lapidosis mtis Maglić”, Aug-1906, J. Rohlena (sub “E. esula b) magličensis m.”) (PRC barcode 452975 [photo!] https://plants.jstor.org/stable/viewer/10.5555/ al.ap.specimen.prc452975); isolectotype: Aug-1906, J. Rohlena (58 BM barcode 000751501).

= Euphorbia pancicii Beck, Glasn. Zemaljsk. Muz. Bosni Hercegovini 32: 95 (1920) [“Pančićii”], syn. nov. 三 Tithymalus pancicii (Beck) Soják, Čas. Nár. Mus., Odd. Př́r. 140: 175 (1972).

IND. LOC.: "Na vapnenastim stijenama u dolini Rzave, kod Dobruna, u Razdolini kod 400 do 450 m, blizu Strmice na Limu (K. Maly kao E. variabilis)". LECTOTYPE (here designated by A. R. Smith, 08-Oct1964): [Bosnia] "An felsen nächat Strmica am Lim, Kalk felsen und Shutt; ca. 450 m", 12-Apr-1910, K. Malý (sub "? E. variabilis") (K barcode 000911842 [photo!] https://plants.jstor.org/stable/viewer/10.5555/ al.ap.specimen.k000911842?loggedin=true). 
- “Euphorbia variabilis" sensu Pančić, Fl. Serbiae: 612 (1874) [non Ces., Bibl. Ital. (Milan) 91:348 (1838)]; K. Malý, Magyar Bot. Lapok 8(1-4): 93.

The first indication that this is a new taxon ("E. species proxima virgatae sed diversa") was given by Pančić (1867) for W Serbia (vicinity of Mokra Gora). The same data was represented in the Flora of the Principality of Serbia (Pančić 1874) as E. variabilis Ces. (currently known only from the Alps). The first description and diagnosis of the taxon were presented by Maly (1909) who found the same plant in E Bosnia (Dobrun) near the mentioned Pančić's site in W Serbia. He expressed suspicion that the plant belongs to E. variabilis, but did not formally describe a new taxon. He was followed by Beck (1920), who described E. pancicii based on Pančić's and Malý's material. Under that name, the plant was recognized in Prodromus Florae peninsulae Balcanicae (Hayek 1924) and Flora of SR Serbia (Janković \& Nikolić 1972), and it was also mentioned for the flora of Montenegro (Blečić 1953). However, in the Flora Europaea (Smith \& Tutin 1968) species was wrongly treated as a synonym of $E$. esula L. subsp. esula. Although this calciphyllous East Illyrian plant really belongs to a very variable complex of the widespread Eurasian E. esula, it differs in many morphological and ecological characteristics, that were thoroughly presented by Wraber (1982) and accepted in Niketić (2014). In addition, it differs phenologically by flowering already in April-May in the lower altitudes. Nevertheless, in the current lists (e.g. Govaerts et al. 2020) the taxon is still treated as a variety of E. esula.

The same plant was independently described by Rohlena (1913) from NW Montenegro on the border with Bosnia and Herzegovina (Mt Maglić) under the name E. maglicensis. Based on the following citation in the protologue: "Rasse der E. esula L. (= E. maglićensis m.)", it remains unclear whether the author described the species or the variety, especially if we keep in mind that on the original herbarium label (PRC, BM), as well as in Rohlena (1942), the taxon was treated as a variety. However, it is more probable that the author initially used the term "race" in the sense of microspecies, not as an indication of rank. Hayek (1924), in addition to $E$. pancicii, also mentioned this plant as E. esula var. maglicensis (Rohlena) Hayek. Inspection of the original material of E. pancicii (K) and E. maglicensis ( $\mathrm{PRC}, \mathrm{BM}$ ) showed that they are conspecific, but clearly different from E. esula. Although the name E. maglicensis has long been neglected, it has priority over E. pancicii (Art. 11). 
102 Niketić, M. ET AL.: ANNOTAted Checklist of VAscular Flora OF SeRBia II

\section{Floristic notes}

New and confirmed taxa for the flora of Serbia

\section{LILIOPSIDA}

LILIACEAE (XANTHORRHOEACEAE)

Asphodeline taurica (Pall. ex M. Bieb) Endl., Cat. Horti Vindob. 1: 142 (1842).

Two species of the genus Asphodeline Rchb. are reported for the flora of Serbia: A. liburnica (Scop.) Rchb. and A. lutea (L.) Rchb. (Anačkov et

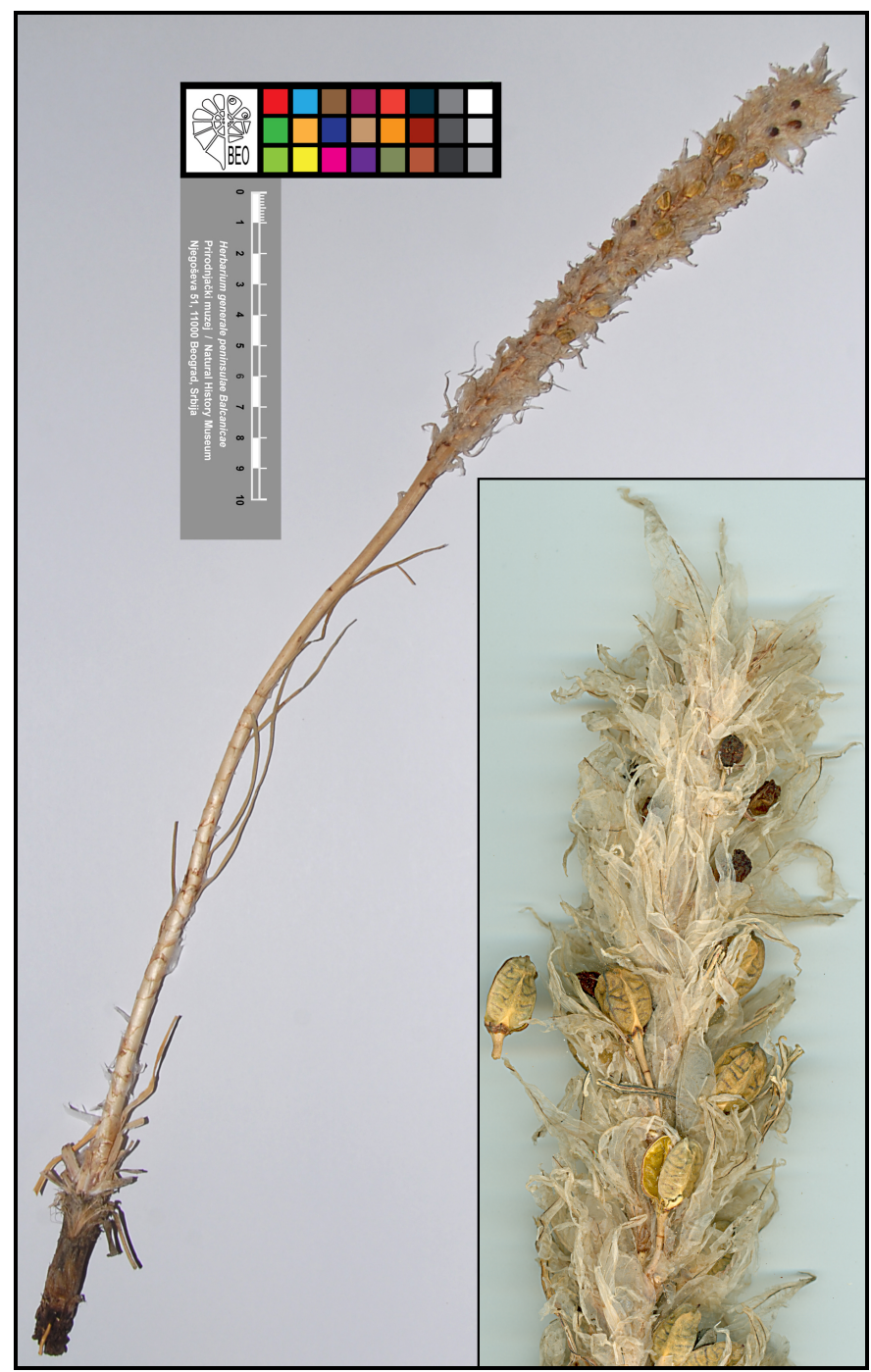

Fig. 3. - Asphodeline taurica (Pall. ex M. Bieb) Endl. (E Serbia, Mt Suva Planina, BEO 100027). 
al. 2018). During the field trip in Mt Suva Planina in E Serbia two individuals of East-Mediterranean A. taurica (Pall. ex M. Bieb) Endl. was found on the edge of a mountain ridge. In the Balkan Peninsula it is known from Bulgaria, Greece and Albania (Govaerts 2020) as well as from North Macedonia (Matveeva 1968). Notable diagnostic characters for this plant are white petals and conspicuous and dense scarious whitish bracts. Unfortunately, the species was not found in the same micro-locality last year. In the wider area of Mt Suva Planina and the surroundings of Niš, within a radius of $12 \mathrm{~km}$, all three species listed for the flora of Serbia were reported. Asphodeline liburnica are reported for the Jelašnica Gorge (Petrović 1882) and also was recently found in Koritnik hill in the foothill of the Mt Suva Planina (coll. M. Niketić BEO). Asphodeline lutea was mentioned by Pančić (1884) for Sićevačka Gorge (Vis peak), but after that it was no longer found at that locality, but only A. liburnica previously reported by Petrović (1882). The original Pančić's material of $A$. lutea was not found in BEOU. Niketić (2010) preliminary announced its alleged presence in Mt Suva Planina, but this record actually correspond to $A$. taurica.

\section{First record:}

E Serbia, Suva Planina, Sokolov Kamen peak, limestone, rocky ground along the ridge, $1350 \mathrm{~m}$, MGRS 34T EN98, coll. M. Niketić 04-Jul1989, det. M. Niketić (BEO 100027) (Figs 3, 16).

A new species for the flora of Serbia. Probably extinct.

M. Niketić

\section{Poaceae (GRAmineae)}

Poa stiriaca Dörfl., Jahreskat. Wiener Bot. Tauschvereins 1904: 226 (1904).

This perennial grass is the only representative of $P$. sect. Leptophyllae J. R. Edmondson in Flora Europaea and its distribution encompasses E and C Europe (Austria, Czech Republic, Poland and Romania). In the Balkan Peninsula it is recorded for Montenegro (Rohlena 1942, Edmondson 1980), Bosnia and Herzegovina (Stefanović 1960), SE Albania (De Sanctis et al. 2018) and NW Greece (Dimitrov \& Vutov 2015). Previous unreferenced and unverified data of its presence in Serbia (Svoboda 2012) was not supported either by herbarium specimens, nor by specific data for a certain locality, and it was disputed by Lakušić et al. (2018) and Niketić et al. (2018b). The newly-discovered locality of P. stiriaca in Mt Suvobor represents the most continental finding of the species in the Balkan Peninsula. In all three localities in Serbia (Fig. 16) this species grows in ultramaphitic geological substrate, in Erico-Quercetum dalechampii forest 
or different types of Pinus nigra J. F. Arnold forests at the elevation between 700 and $1520 \mathrm{~m}$ a.s.l. Within its range, $P$. stiriaca was found on various types of bedrock, also including ultramaphitic substrate in Austria (Eggler 1955) and Greece (Dimitrov \& Vutov 2015).

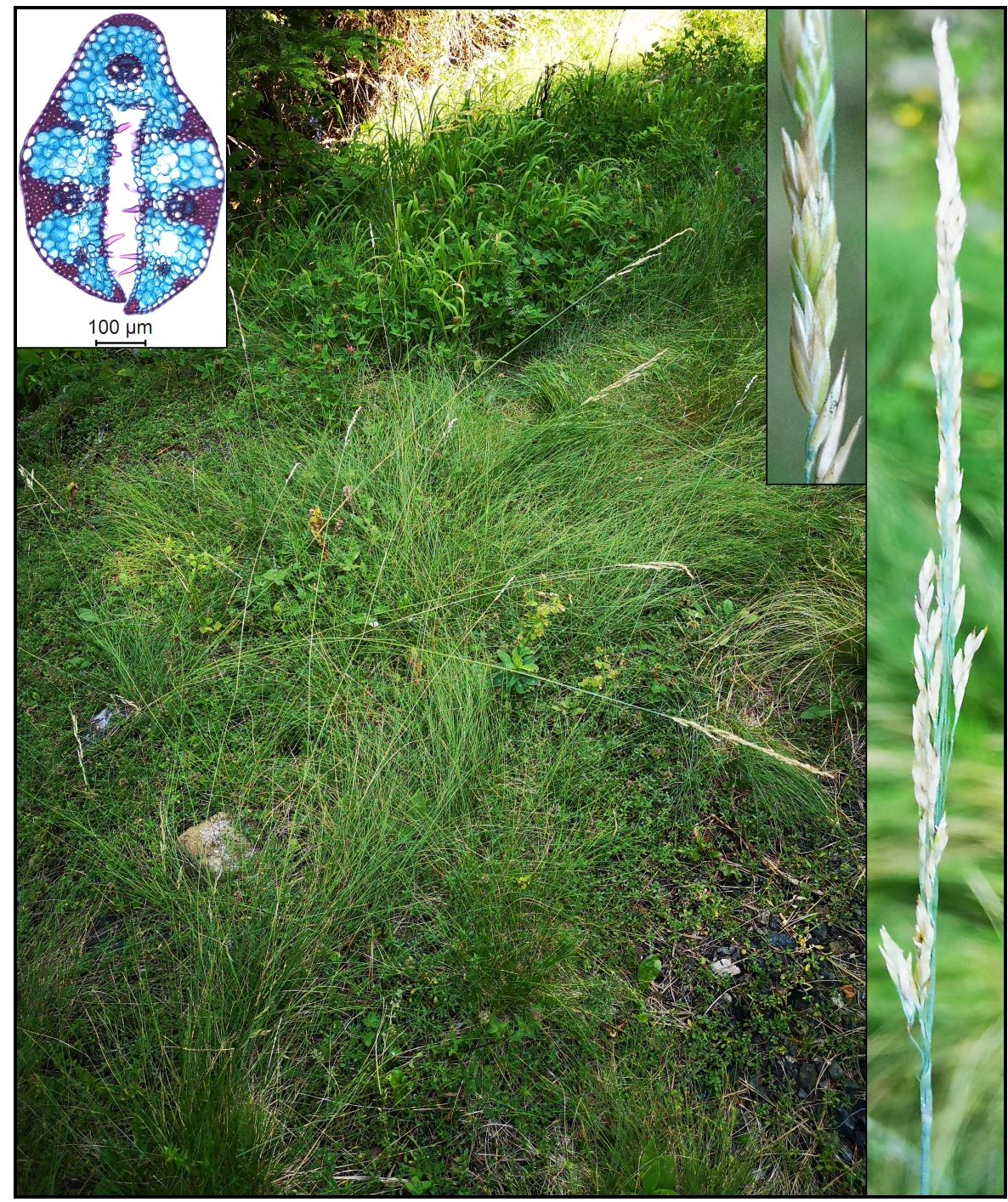

Fig. 4. - Poa stiriaca Dörfl. (SW Serbia, Mt Ozren BEO, 100009).

First records:

SW Serbia, Mt Ozren near Sjenica, Čir, ultramaphite, roadside in the Pinus nigra forest, $1520 \mathrm{~m}$, MGRS 34T DN08, $19.8050839 \mathrm{E}$, 43.2448787 N, coll. M. Niketić, G. Tomović 30-Jul-2020, det. M. Niketić (BEO 100009) (Fig. 4). 
NW Serbia, Mt Maljen, Divčibare, Crni Vrh peak, Kičer, ultramaphite, Brachypodio-Pinetum nigrae, 1042 m, MGRS 34T DP18, 19.99488 E, $44.09031 \mathrm{~N}$, coll. D. Lakušić 27-Sep-2020, det. D. Lakušić, (BEOU 50851).

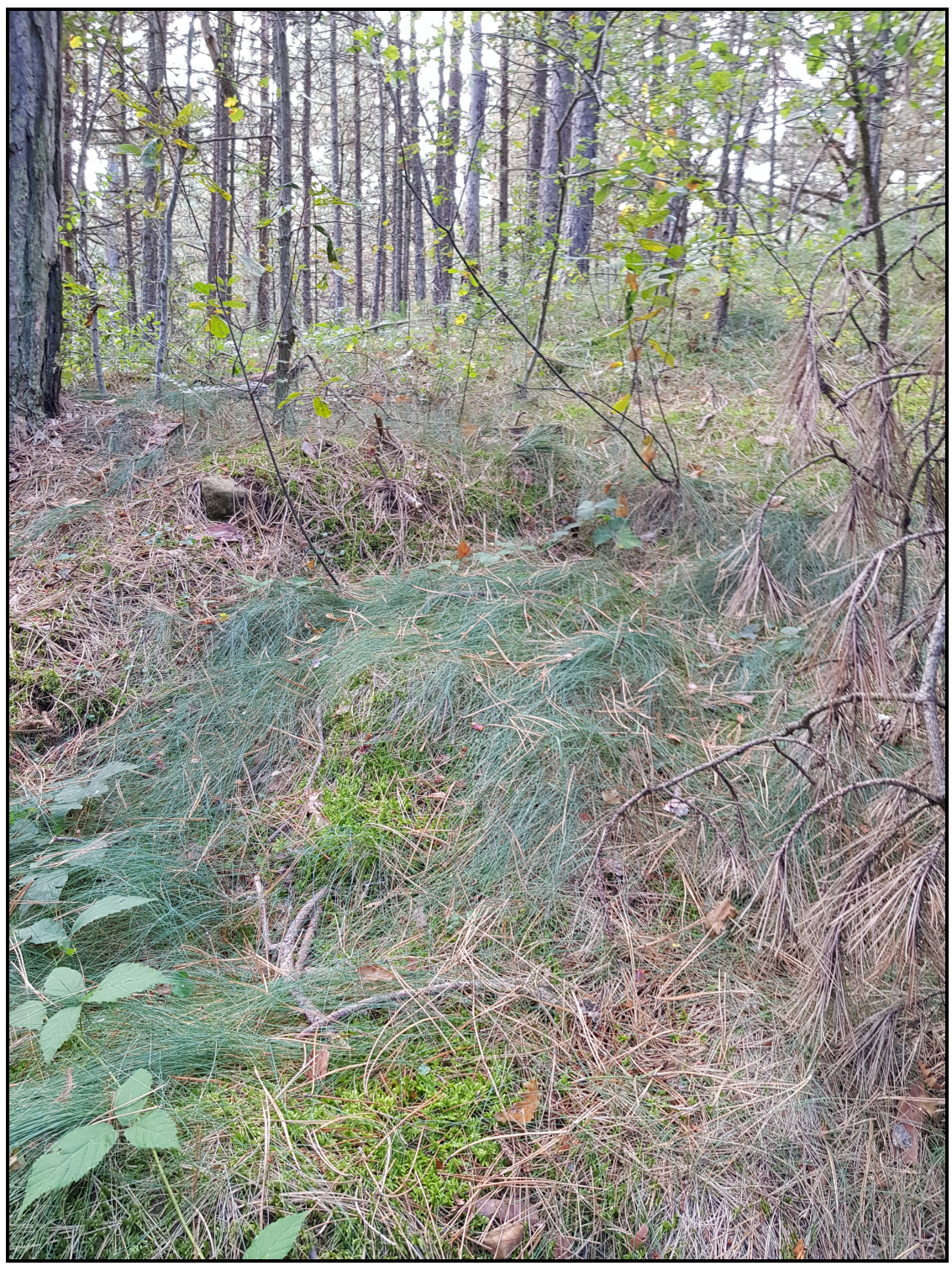

Fig. 5. - Poa stiriaca Dörfl. (NW Serbia, Mt Maljen) (photo D. Lakušić).

NW Serbia, Mt Maljen, Divčibare, Crni Vrh peak, Kičer, ultramaphite, Brachypodio-Pinetum nigrae, 1010 m, MGRS 34T DP18, 19.99347 E, 44.09083 N, D. Lakušić 27-Sep-2020 (field observ.). 
NW Serbia, Mt Maljen, Tometino Polje, Rastovac, ultramaphite, EricoPinetum nigrae, 818 m, MGRS 34T DP18, 19.99781 E, 44.07844 N, D. Lakušić 27-Sep-2020 (field observ.).

NW Serbia, Mt Maljen, Tometino Polje, Rastovac, ultramaphite, Pinetum nigrae, 806 m, MGRS 34T DP18, 19.99755 E, 44.07894 N, D. Lakušić 27-Sep-2020 (field observ.).

NW Serbia, Mt Suvobor, Nateme, ultramaphite, Erico-Quercetum dalechampii forest, 688 m, MGRS 34T DP38, 20.168641 E, 44.134539 N, coll. N. Kuzmanović, I. Stevanoski, 08-Oct-2019, det. N. Kuzmanović (BEOU 63632) (Fig. 5).

Confirmed and for the first time located species for the flora of Serbia.

M. Niketić, G. Tomović, D. Lakušić, N. Kuzmanović, I. Stevanoski

\section{MAGNOLIOPSIDA}

APIACEAE (UMBELLIFERAE)

Sison amomum L., Sp. Pl.: 252 (1753).

In the flora of Europe and the Mediterranean there are three species of the genus Sison L. (Tutin 1968, Hand 2011): S. amomum L., S. exaltatum Boiss. and $S$. segetum L. of which $S$. exaltatum is present in E Mediterranean (Israel, Lebanon and Syria), S. segetum is distributed in the W Europe, while $S$. amomum has the widest distribution range that encompasses W and S Europe, Asia Minor and N Africa (Maslo et al. 2020 and literature therein). In the Balkan Peninsula this species is present in Albania (Barina et al. 2011), Bulgaria, Croatia, Greece, Romania and Turkey in Europe (Hand 2011) and only recently it was recorded as a new species for the flora of Bosnia and Herzegovina (Maslo et al. 2020).

Sison amomum was mentioned for the first time for the flora of Serbia by Stojanović \& Stevanović (2008) who presented the list of vascular plant taxa for Mt Gučevo in NW Serbia. Although this was the first mention both of the genus Sison and the species S. amomum in the flora of Serbia, the authors did not point this out in their paper, and they did not provide any details about the exact locality in which this species was collected.

By checking the herbarium material of $S$. amomum in the Herbarium of the Institute of Botany and Botanical Garden "Jevremovac", University of Belgrade (50835 BEOU) it was confirmed that this specimens was correctly identified. By providing additional detail about exact locality, habitat and the date of collecting as well as picture of the herbarium specimen (Fig. 6) we confirm and point out the existence both of the new genus as well as new species for the flora of Serbia. Detail description of 
the genus as well as the species could be found in Tutin (1968) and Maslo et al. (2020).

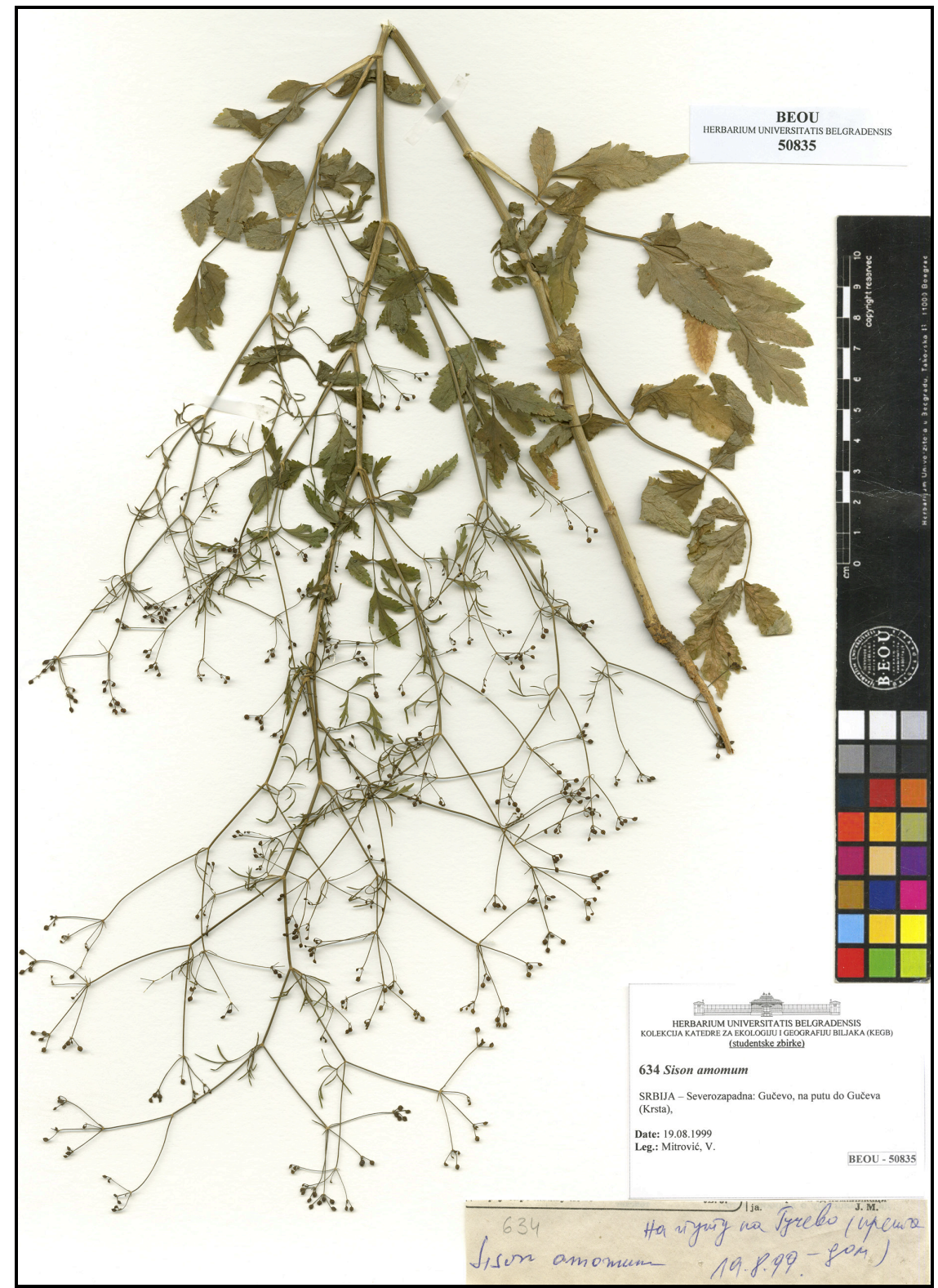

Fig. 6. - Sison amomum L. (NW Serbia, Mt Gučevo, 50835 BEOU).

Finding the species S. amomum on Mt Gučevo (locality Velika Ravan) is not so surprising considering that the nearest newly recorded localities in central and eastern Bosnia (Gornji Srebrenik near Tuzla and Hrvati near 
Banovići) are only c. $60 \mathrm{~km}$ to the west. According to Maslo et al. (2020) this submediterranean-subatlantic plant inhabits the edges of the local roads near Tuzla (the villages Gornji Srebrenik and Hrvati) et the elevations between 360 and $420 \mathrm{~m}$. On Mt Gučevo (locality Velika Ravan) the species was found next to a macadam road, near the wooden fence of a rural abandoned house where water is retained, et elevation c. $530 \mathrm{~m}$.

First record:

NW Serbia, Mt Gučevo, on the road to Gučevo, Velika Ravan, MGRS 34T CQ52, coll. V. Mitrović, 19-Aug-1999, det. V. Mitrović (50835 BEOU) (Figs 6, 16).

Confirmed and for the first time located genus and species for the flora of Serbia.

\section{Stojanović, V. Stevanović}

\section{ASTERACEAE (COMPOSITAE)}

Artemisia dracunculus L., Sp. Pl.: 849 (1753).

Artemisia dracunculus belongs to the subgenus Dracunculus Besser, series Dracunculus (Poljakov 1961). The species is characterized by a wide but disjunctive Holarctic distribution. Most of the area covers the temperate and boreal areas of Eurasia from the European part of Russia in the west to Manchuria and NE China in the east (Meusel \& Jäger 1992). The northern part of the area in Eurasia includes the northeastern part of the boreal zone of Yakutia, and the southern mountainous areas of the Turanian region. The other part of the range includes temperate areas of western and central North America. European part of its natural range includes Belarus, Ukraine, Crimea and Russia to the Urals. Due to the spice tarragon, $A$. dracunculus is grown throughout the Holarctic, as well as in Europe where in many countries such as Poland, Romania, Austria, Switzerland and France the species is naturalized (subspontaneous) (Greuter 2006+).

Its status in the countries where it is still grown (Norway, Belgium, Germany, Latvia, Estonia) is naturalized in some places, while Serbia is listed as a country where it is only grown. Data on tarragon cultivation in Serbia are scarce and localized. It is stated as cultivated for Deliblato Sands, where after the Second World War there were trial areas where the possibilities of its cultivation were explored. According to Šajinović \& Mihajlov (1979), it was introduced in the period between 1960 and 1965 in the localities of Devojački Bunar and Dubovac, and after only ten years it spreads outside the plantations. According to the same authors, experimental studies of the introduction of about 400 medicinal plants have shown that $A$. dracunculus is one of the four species that are best adapted to the climate. 


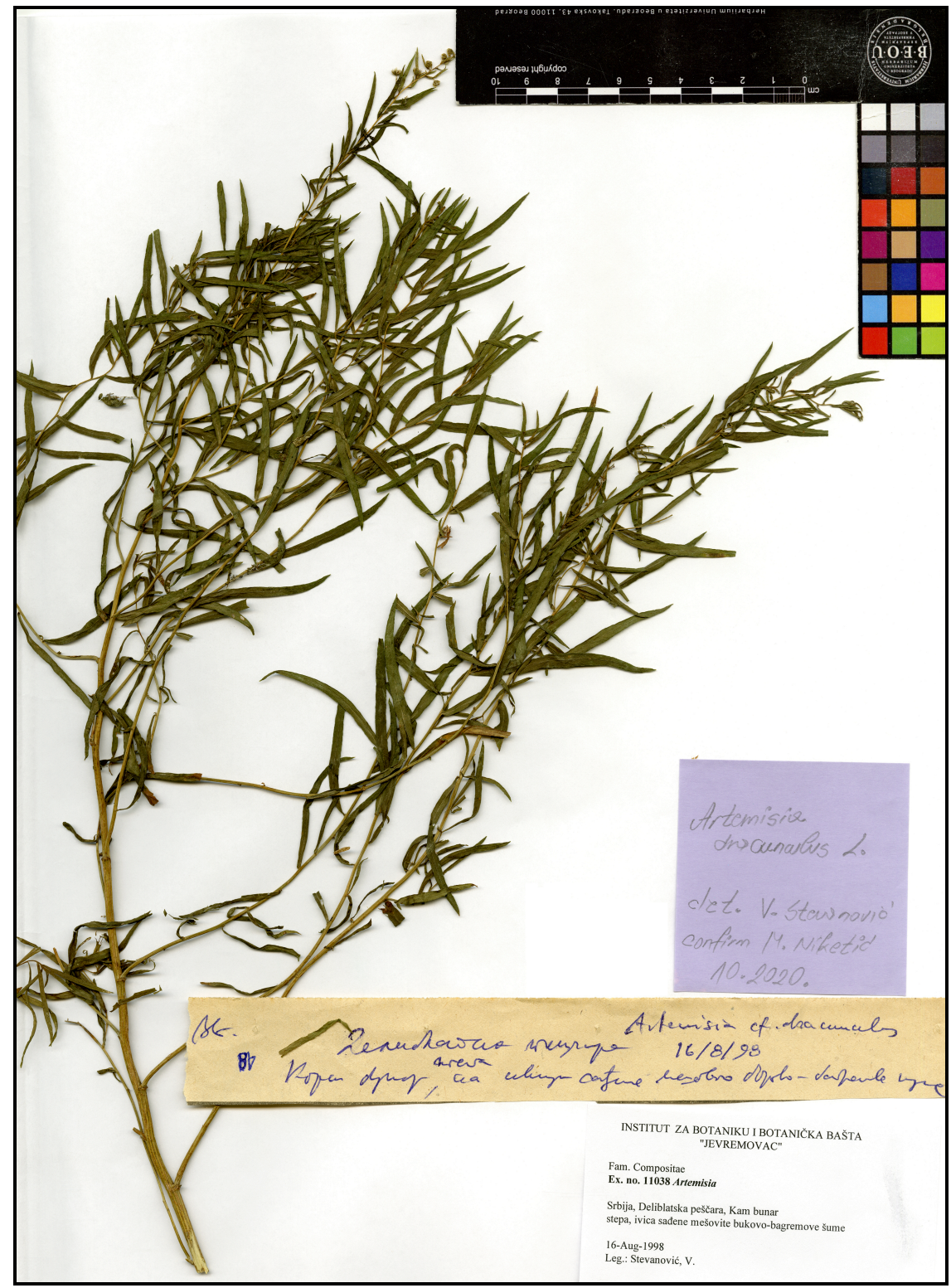

Fig. 7. - Artemisia dracunculus L. (Banat, Deliblatska Sands, 11038 BEOU).

Almost 30 years later, this species was found along the Sušara - Korn road, c. $1 \mathrm{~km}$ from the place on the Korn Bunar (BEOU). The population of $A$. dracunculus in this locality is small (only a dozen specimens were found) and is located on a steamed surface of Robinia pseudoacacia L. forest surrounded by shrubs Crataegus monogyna Jasq., Ligustrum vulgare L. and Euonymus europaeus L. It can be assumed that this small population 
originates from nearby plantations of medicinal herbs, most likely from Korn or Sušara. It is possible that this species could be also found in other parts of the Deliblato Sands.

First record:

Banat, Deliblatska Sands, Korn Bunar, steppe and the edge of a planted Robinia pseudoacacia forest, sand, MGRS 34T EQ07, coll. V. Stevanović, 16-Aug-1998, det. V. Stevanović (11038 BEOU) (Fig. 7).

Confirmed and for the first time located allochthonous species for the flora of Serbia.

V. Stevanović, M. Niketić, G. Tomović

Centaurea austrobalcanica subsp. prisadana (Skokanová) Raus \& Strid, Phytol. Balcan. 26(3): 505 (2020).

三 Cyanus austrobalcanicus Skokanová, P1. Syst. Evol. 305: 590 (2019) [basionym].

- "Centaurea nissana" sensu Ranđelović \& Stamenković, Leskovački zbornik 24: 377 (1984) [non Petrović, Addit. Fl. Agr. Nyss.: 110 (1885)].

- "Centaurea napulifera subsp. tuberosa" sensu Zlatković, V. Randjelović \& N. Randjelović, III Simp. fl. jugoist. Srbije: 104 (1993) [non (Vis.) Stoj. \& Acht., Stud. Centaur. Bulg.: 22 (1935)].

Ranđelović \& Stamenković (1984) were the first botanists who found this Balkan endemic plant in Mt Rujan and near Preševo in S Serbia. However, they published this record under the name C. nissana Petrović. This data was also cited by Ranđelović \& Stamenković (1985) (sub $C$. nissana Petrović) and Zlatković et al. (1993) (sub C. napulifera subsp. tuberosa) from the same locality. According to Greuter (2006+) Cyanus tuberosus (Vis.) Soják (= Centaurea tuberosa Vis.) is distributed in Albania, Bosnia and Herzegovina, Bulgaria, Croatia, Greece, Montenegro, North Macedonia and Serbia.

However, according to the most recent genetic, morphological, ecological and phenological study of Skokanová et al. (2019) the C. tuberosus group is extensively radiated and comprises nine almost allopatric genetic lineages within eight Balkan endemic species. One of them is Cyanus austrobalcanicus Skokanová which comprises two subspecies: C. a. subsp. austrobalcanicus distributed in $\mathrm{N}$ Greece and $\mathrm{S}$ Bulgaria and C. a. subsp. prisadanus Skokanová present in North Macedonia and possibly in NC Greece. Although Skokanová et al. (2019) did not mention that the last 


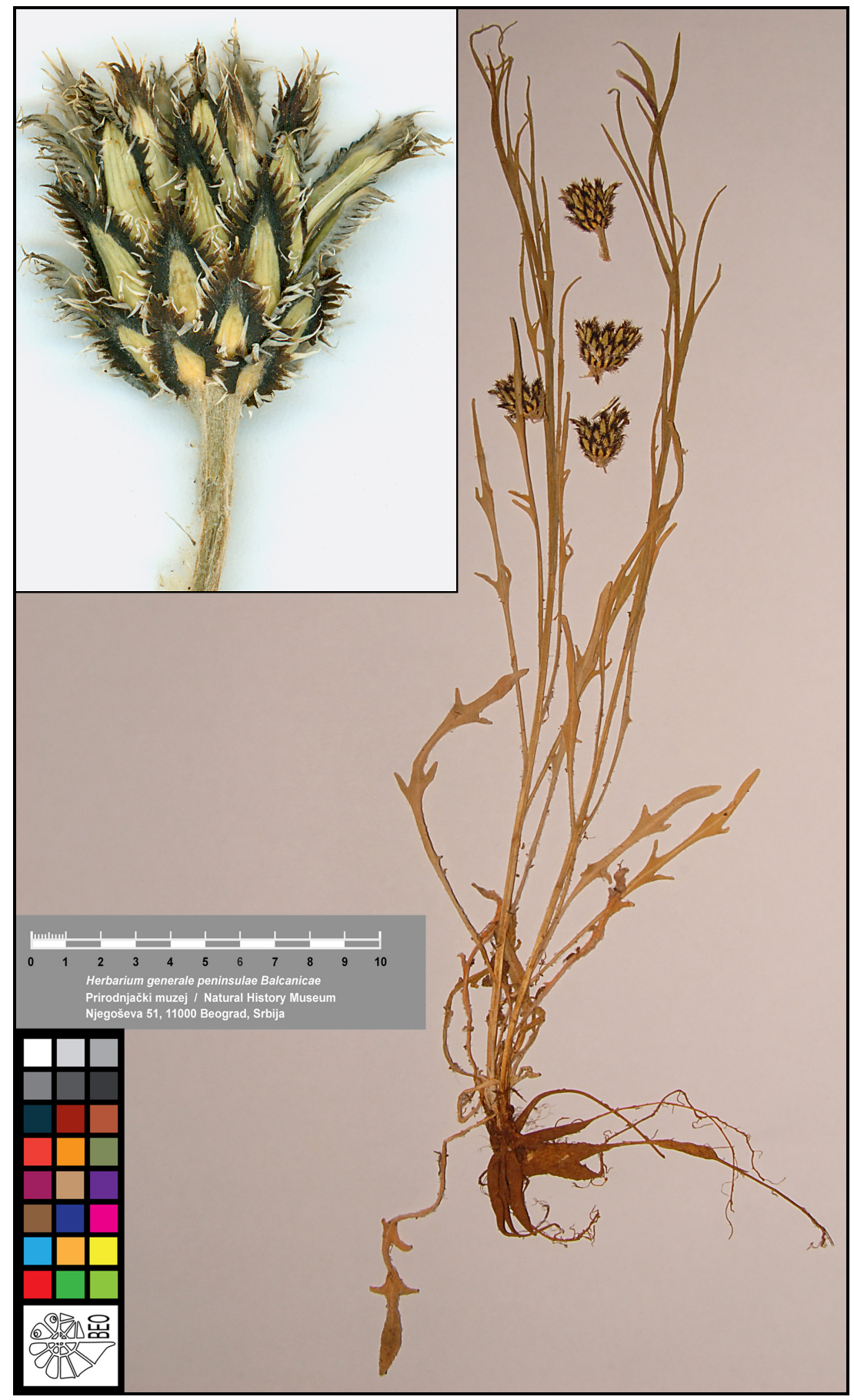

Fig. 8. - Centaurea austrobalcanica subsp. prisadana (Skokanová) Raus \& Strid (S Serbia, Mt Rujan Planina, BEO 100019). 
subspecies grows also in Serbia, the close proximity of the North Macedonian populations (e.g. Mt Vodno), as well as comparison of the herbarium specimens from S Serbia with diagnosis presented in the paper for subsp. prisadanus, confirms its presence in Mt Rujan.

Most recently Raus \& Strid (2020) published new combination in some Balkan Centaurea taxa. One of them is Centaurea austrobalcanica subsp. prisadana (Skokanová) Raus \& Strid and their attitude is accepted in this paper.

\section{First records:}

S Serbia, Mt Rujan Planina, Cer village, solo silicicolo, in pascuis, 500 m, MGRS 34T EM57, coll. M. Niketić 14-May-1991, det. S. Bancheva (sub C. tuberosa), rev. M. Niketić 01-Apr-2020 (BEO 100019) (Figs 8, 16).

S Serbia, Mt Rujan Planina, Orljak, 742 m, limestone, stony pastures, coll. \& det. M. Niketić, G. Tomović 03-May-2009 (sub C. tuberosa) (29576 BEOU).

A new species and subspecies for the flora of Serbia.

\section{Niketić, G. Tomović}

Hieracium pseudofastigiatum Degen \& Zahn, Magyar Bot. Lapok 5: 68 (1906).

$\equiv$ Hieracium umbrosum subsp. pseudofastigiatum (Degen \& Zahn) Zahn in Engl., Pflanzenr. 76: 794 (1921).

Hieracium pseudofastigiatum belongs to $H$. umbrosum group $(H$. murorum - prenanthoides) together with $H$. eugraptum Omang, $H$. umbrosum Jordan, H. vipetinum Huter ex Freyn (Sell \& West 1976) and 16 additional taxa (Greuter 2006+). It is a Balkan subendemic species previously known from Albania, Bulgaria, North Macedonia and Romania (Greuter 2006+). During floristic exploration of the Đerdap Gorge in NE Serbia it was also found on locality Ploča, near the road in the zone of Quercus cerris L. and $Q$. frainetto Ten. It was previously also recorded from Mt Domogled in Romania (Zahn 1937), 33 km northeast from Serbian population.

First record:

NE Serbia, Đerdap Gorge, Ploča, limestone, asphalt road, MGRS 34T FQ04, coll. S. Vukojičić, G. Tomović, "ENDEMIT" 15-Jul-2001, det. M. Niketić (13374 BEOU) (Fig. 9).

A new species for the flora of Serbia. 


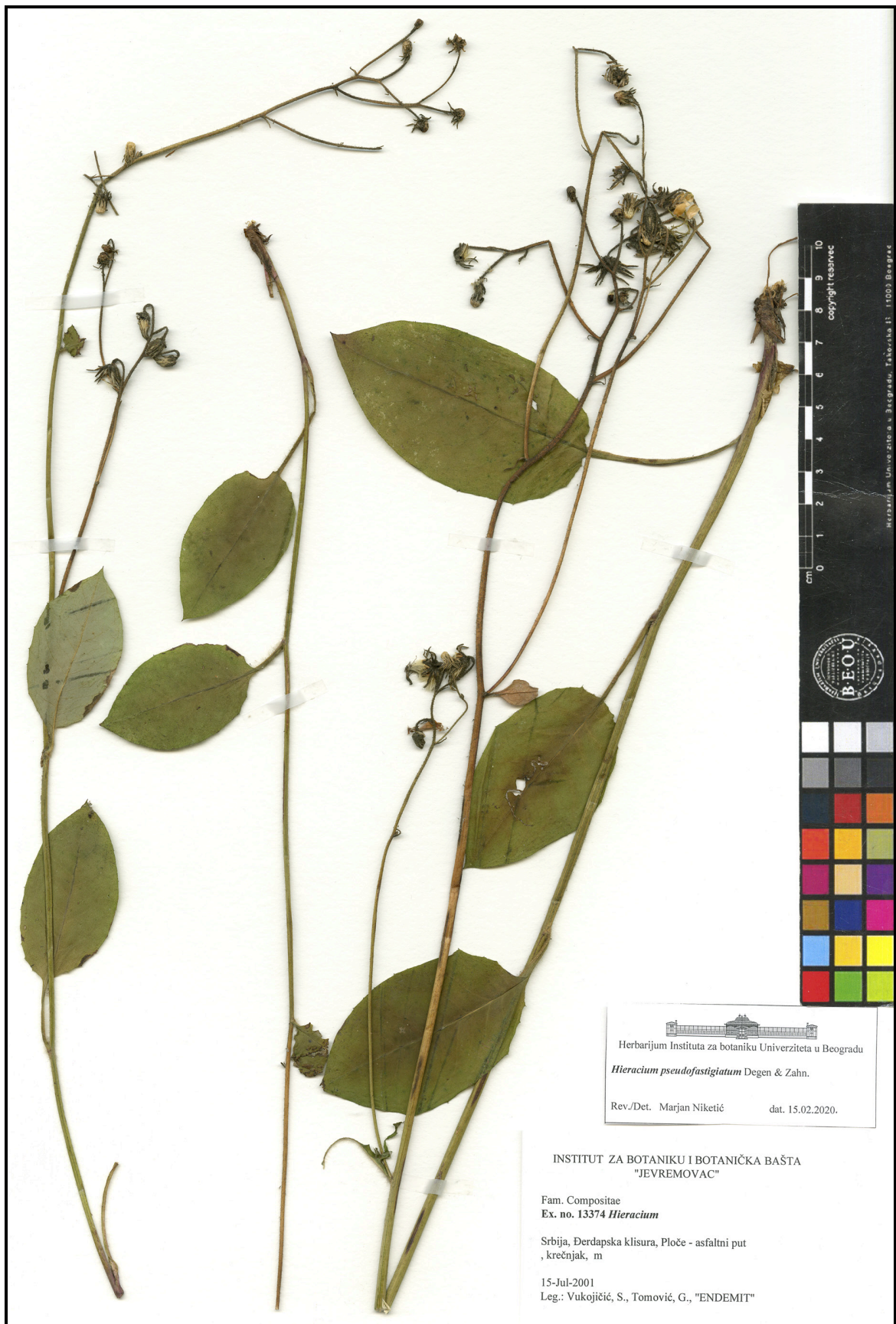

Fig. 9. - Hieracium pseudofastigiatum Degen \& Zahn (NE Serbia, Đerdap Gorge, 13374 BEOU). 
Leucanthemum illyricum (Horvatić) Vogt \& Greuter, Willdenowia 33: 41 (2003).

[Papeš, Acta Bot. Croat. 32: 244 (1973), comb. inval.]

$\equiv$ Chrysanthemum croaticum var. illyricum Horvatić, Acta Bot. Inst. Bot. Univ. Zagreb. 3: 89 (1928) [basionym]; Leucanthemum atratum subsp. illyricum (Horvatić) Soó, Acta Bot. Acad. Sci. Hung. 23: 386 (1978).

- "Chrysanthemum chloroticum" sensu K. Malý, Glasn. Zem. Muz. Saraj. 46: 53 (1934) [non (A. Kern. \& Murb.) Horvatić, Acta Bot. Inst. Bot. Univ. Zagreb 3: 102 (1928)].

- "Chrysanthemum croaticum" sensu Vukićević, Glasnik Šumarskog fakulteta 29: tab. 10 (1965) [non Horvatić, Acta Bot. Inst. Bot. Univ. Zagreb 3: 89 (1928)].

This Balkan endemic species inhabits rocky grasslands and rock crevices in subalpine belt and gorges in C and E Dinarides (Horvatić 1928, Papeš 1973). It was very often confused with parapatric Dinaric species, $L$. visianii (Gjurašin) Vogt \& Greuter [= L. croaticum (Horvatić) Bjelčić $]$ and L. chloroticum Kern. \& Murb. ex Murb., that also have \pm fleshy glabrescent leaves. Leucanthemum illyricum is characterized by more robust growth, coarsely dentate leaves and larger capitula. In the past period, this species was also found in Mt Tara in W Serbia in many places in the rocky habitats of Ostrya carpinifolia Scop. and Picea omorika (Pančić) Purk. communities (BEO 100016). Previous record of L. chloroticum (Malý 1934) ["Chrysanthemum chloroticum"] from the same mountain undoubtedly corresponds to L. illyricum. Through the revision of herbarium material, its presence in the area of Prokletije Mts in Metohija was confirmed (BEO 25584) (Fig. 16). Previous report of L. visianii (Vukićević 1965) from the Serbian part of Prokletije Mts probably also refers to L. illyricum.

First record:

W Serbia, Mt Tara, Kozje Stene, limestone, 800-900 m, MGRS 34T CP76, coll. M. Niketić 3-Jul-1988, det. M. Niketić (BEO 100016) (Figs $10,16)$.

Metohija, Prokletije Mts, monast. Dečani, in the bush near Dečanska Bistrica river, MGRS 34T DN31, coll. P. Černjavski, I. Rudski, V. Lindtner 14-Jul-1933, det. P. Černjavski (sub L. vulgare), rev. M. Niketić 16-Mar-2020 (BEO 25584).

A new species for the flora of Serbia. 


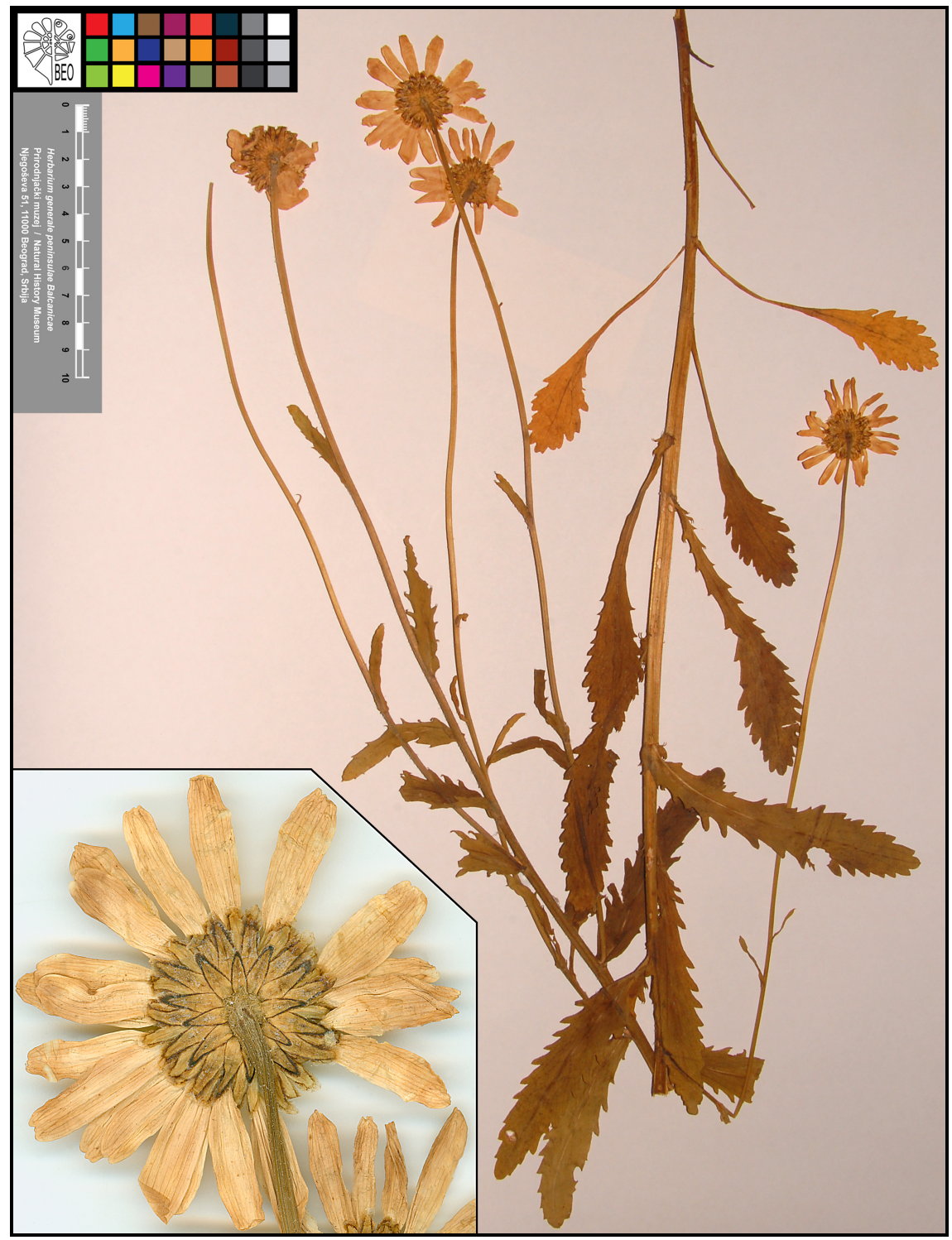

Fig. 10. - Leucanthemum illyricum (Horvatić) Vogt \& Greuter (W Serbia, Mt Tara, BEO 100016).

\section{Niketić}

Rudbeckia hirta L., Sp. Pl.: 907 (1753).

This species is native to North America and widely cultivated for ornamental and naturalized in waste places, river banks and woods mainly in C Europe (Hansen 1976). Concerning neighboring countries it has 
naturalized status in Hungary and unknown status in Romania [Greuter $(2006+)$ ]. In Italy it has status of naturalized alien (NAT) (Galasso et al. 2018) while in Croatia it is treated as allochthonous species out of cultivation (Nikolić 2020). According to criteria of Niketić \& Tomović (2018) its invasive status in Serbia is considered to be: A(A) (initial phase of naturalization).

\section{First record:}

NE Serbia, Kučevo, Vrelo, Marica, gravelly substrate, roadside, $320 \mathrm{~m}$, MGRS 34T EQ52, 21.6961 E, 44.51587 N, coll. M. Niketić, G. Tomović 13-Jun-2020, det. M. Niketić (BEO 100028) (Figs 11, 16).

A new allochthonous species for the flora of Serbia.

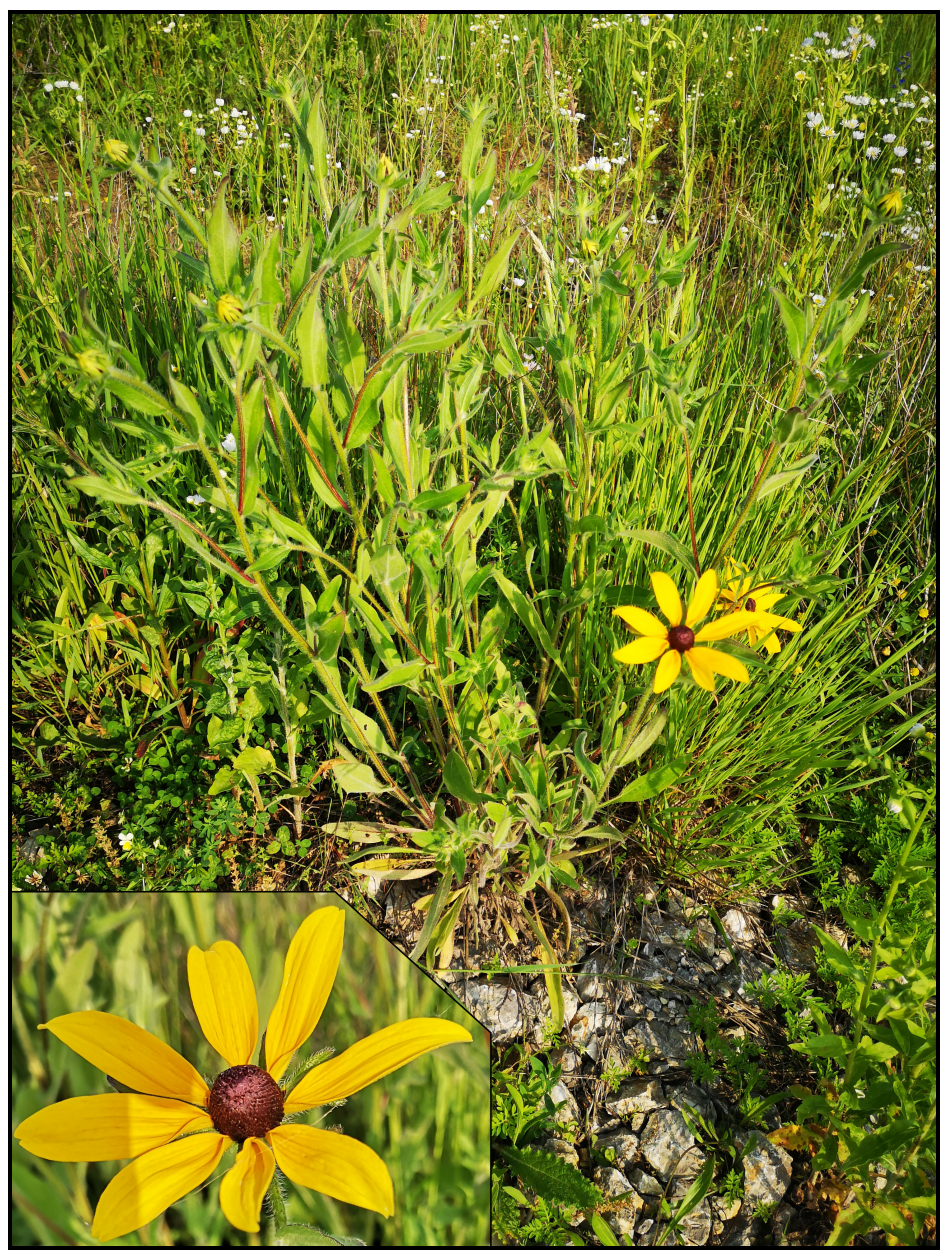

Fig. 11. - Rudbeckia hirta L. (NE Serbia, Kučevo, Vrelo) (photo M. Niketić). 


\section{BORAGINACEAE}

Brunnera macrophylla (Adams) I. M. Johnston, Contr. Gray Herb. 73: 54 (1924).

\section{三 Myosotis macrophylla Adams, Beitr. Naturk. 1: 46 (1805) [basionym].}

It is a single representative of the genus Brunnera Steven in the flora of Europe native to the Transcaucasia (Azerbaijan, Armenia and Georgia) and the Caucasus (Turkey). Brunnera macrophylla is introduced in Great Britain,

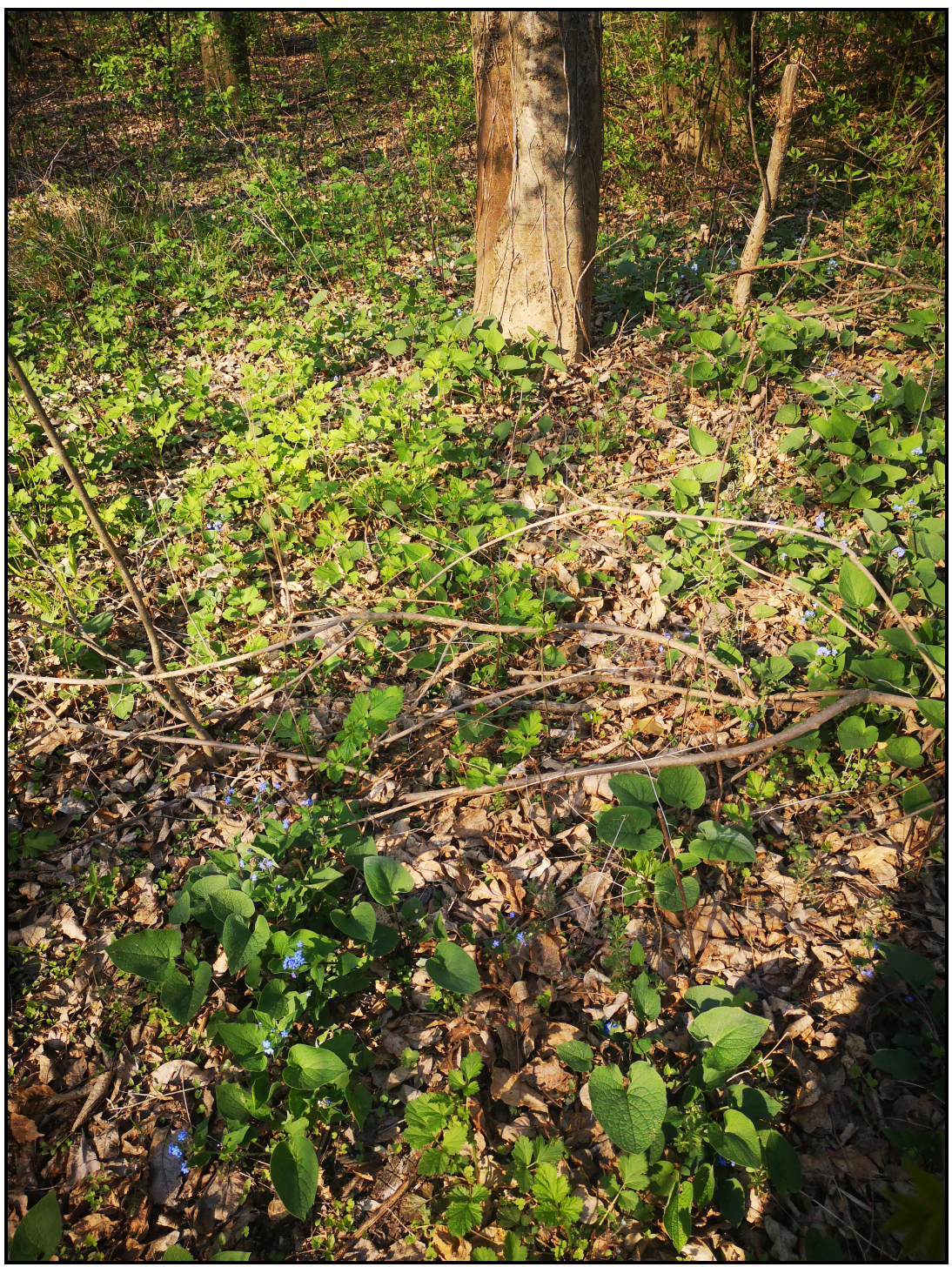

Fig. 12. - Brunnera macrophylla (Adams) I. M. Johnston (Šumadija, Beograd, Zvezdara) (photo M. Niketić). 
Germany, Switzerland, Austria, Slovakia and Czech Republic (Chater 1972, Valdés 2011), while in Italy it has status of naturalized alien (NAT) (Galasso et al. 2018). To our knowledge, this species has not been found in neighboring countries so far. In the urban part of Belgrade it was found in the park-forest Zvezdara in the zone of Quercus robur L., but with domination of some invasive and cultivated trees. Although it was found to have escaped from cultivation, it spread to the forest ecosystem. Its invasive status in Serbia according to criteria of Niketić \& Tomović (2018) is: $A(A) c$ (initial phase of naturalization, also cultivated).

First record:

Šumadija, Beograd, Zvezdara, park-forest Zvezdara, MGRS 34T DQ66, 20.50238 E, 44.81161 N, coll. M. Niketić 07-Apr-2020, det. M. Niketić (BEO 100017) (Figs 12, 16).

A new allochthonous species for the flora of Serbia, escaped from cultivation.

M. Niketić, G. Tomović

\section{BRASSICACEAE (CRUCIFERAE)}

Alyssum wierzbickii Heuff., Flora 18: 242 (1835).

Species was described from SW Romania and it is also distributed in E Serbia and W Bulgaria (Španiel et al. 2017). For the flora of Serbia it was reported for Mt Ozren (Leskovik) near Sokobanja, Mt Stol near Bor and Mt Rtanj (Pančić 1874, Formanek 1896, Diklić 1972, Nikolić et al. 1986). So far, only material from Mt Ozren has been detected (coll. J. Pančić BP, W) (Španiel et al. 2017). Its presence was confirmed on the border with Bulgaria during field research as well as in herbarium material.

\section{New records:}

E Serbia, Stara Planina, Toplodolska river - right bank, beach forest, MGRS 34T FN39, FP30, coll. V. Nikolić, N. Diklić 25-Jun-1958, det. M. Niketić (BEO 42200).

E Serbia, Mt Ruj Planina, from Štrbi Kamik to Zdravči Kamik, rocky grounds and high-mountain pastures, limestone, $1273 \mathrm{~m}$, MGRS 34T FN24, coll. M. Niketić, G. Tomović 30-Jun-2016, det. M. Niketić (BEO 100023) (Figs 13, 16).

E Serbia, Mt Ruj Planina, Štrbi Kamik peak,rocky grounds and highmountain pastures and herb vegetation, limestone, $1480 \mathrm{~m}$, rudine, MGRS 34T FN24, coll. M. Niketić, G. Tomović 30-Jun-2016, det. M. Niketić (BEO 100024).

Confirmed species for the flora of Serbia. 


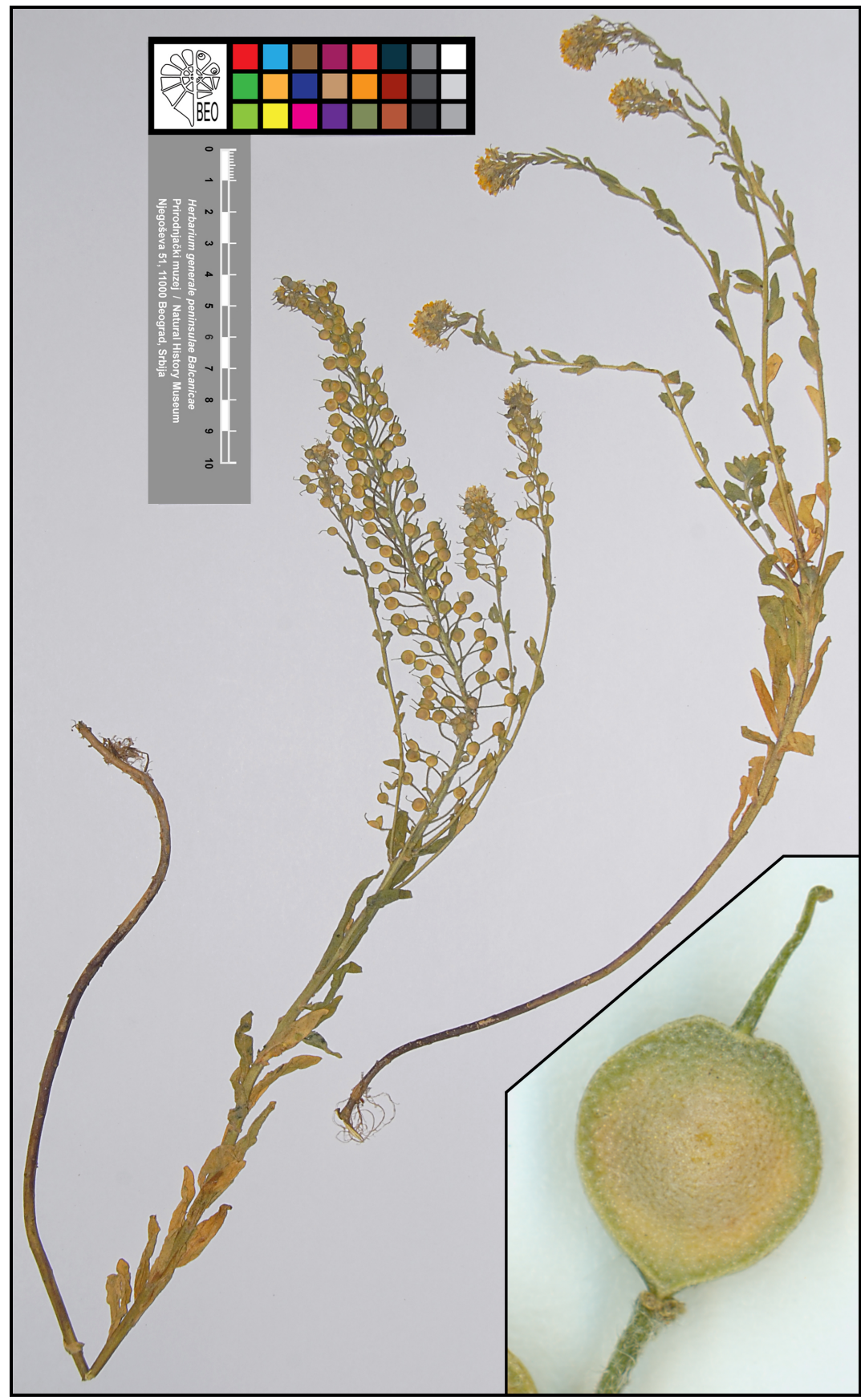

Fig. 13. - Alyssum wierzbickii Heuff. (Mt Ruj Planina, from Štrbi Kamik to Zdravči Kamik, BEO 100023). 


\section{CARYOPHYLLACEAE}

Silene chalcedonica (L.) E. H. L. Krause in Sturm, Deutschl. Fl. (Sturm), ed. 2, 5: 96 (1901).

\section{$\equiv$ Lychnis chalcedonica L., Sp. Pl.: 436 (1753).}

The species was originally described and treated within the genus Lychnis L., which has recently been included in the genus Silene (Jafari et al. 2020). It is native for Central and Eastern Asia and widely cultivated in gardens elsewhere. According to Marhold (2011) it is introduced, as escaped from cultivation, in Finland, Italy, Moldova and Ukraine. There are two historic specimens $(1922)$ in BEO $(5261,5262)$ from NE Serbia and Pomoravlje, but it is not entirely clear from the labels whether the plant was domesticated or cultivated. During the pre-congress excursion of the XVII International Botanical Congress (Vienna 2005) a locally abundant population of $S$. chalcedonica was discovered along the edge of the indigenous oak forest (Quercetum confertae-cerridis Rudski) in Mt Rtanj.

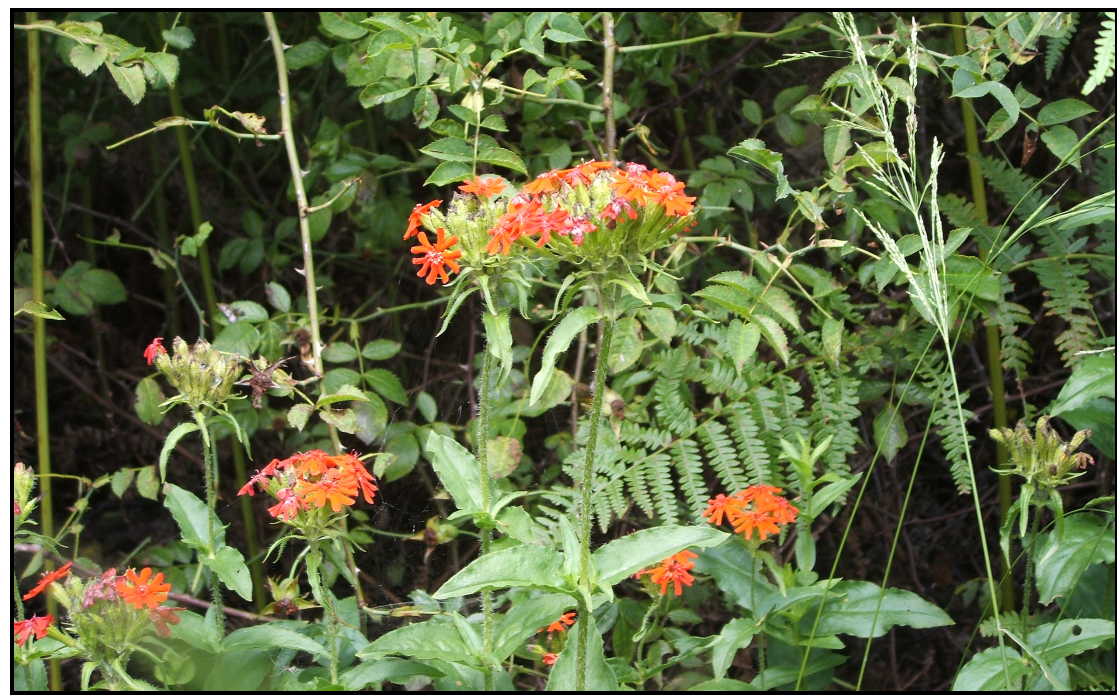

Fig. 14. - Silene chalcedonica (L.) E. H. L. Krause (E Serbia, Mt Rtanj, between villages Rtanj and Nikolinac, BEO 100031) (photo O. Vasić).

First records:

Pomoravlje, Svilajnac and the whole of Resava, MGRS 34T EP19, coll. M. S. Dimitrijević, det. Ž. Jurišić (sub Lychnis chalcedonica) (BEO 5261).

NE Serbia, Bor, Trnjane, MGRS 34T FP09, coll. P. S. Pavlović Jun1922, det. Ž. Jurišić (sub Lychnis chalcedonica) (BEO 5262).

E Serbia, Mt Rtanj, between villages Rtanj and Nikolinac, limestone, the edge of an oak forest, MGRS 34T EP74, coll. O. Vasić 15-Jul-2005, det. M. Niketić (BEO 100031) (Figs 14, 34). 
A new allochthonous species for the flora of Serbia, escaped from cultivation.

\section{O. Vasić, M. Niketić}

Dianthus lakusicii (Wraber) Niketić

$\equiv$ Dianthus nitidus subsp. lakusicii Wraber, Biol. Vestn. 36: 97 (1988) [basionym].

This orophytic plant, closely related to $D$. scardicus Wettst., is endemic for SE Dinarides (see on page 97). It was preliminary enounced by Niketić (2000) for the part of Prokletije Mts in Metohija, near the border with

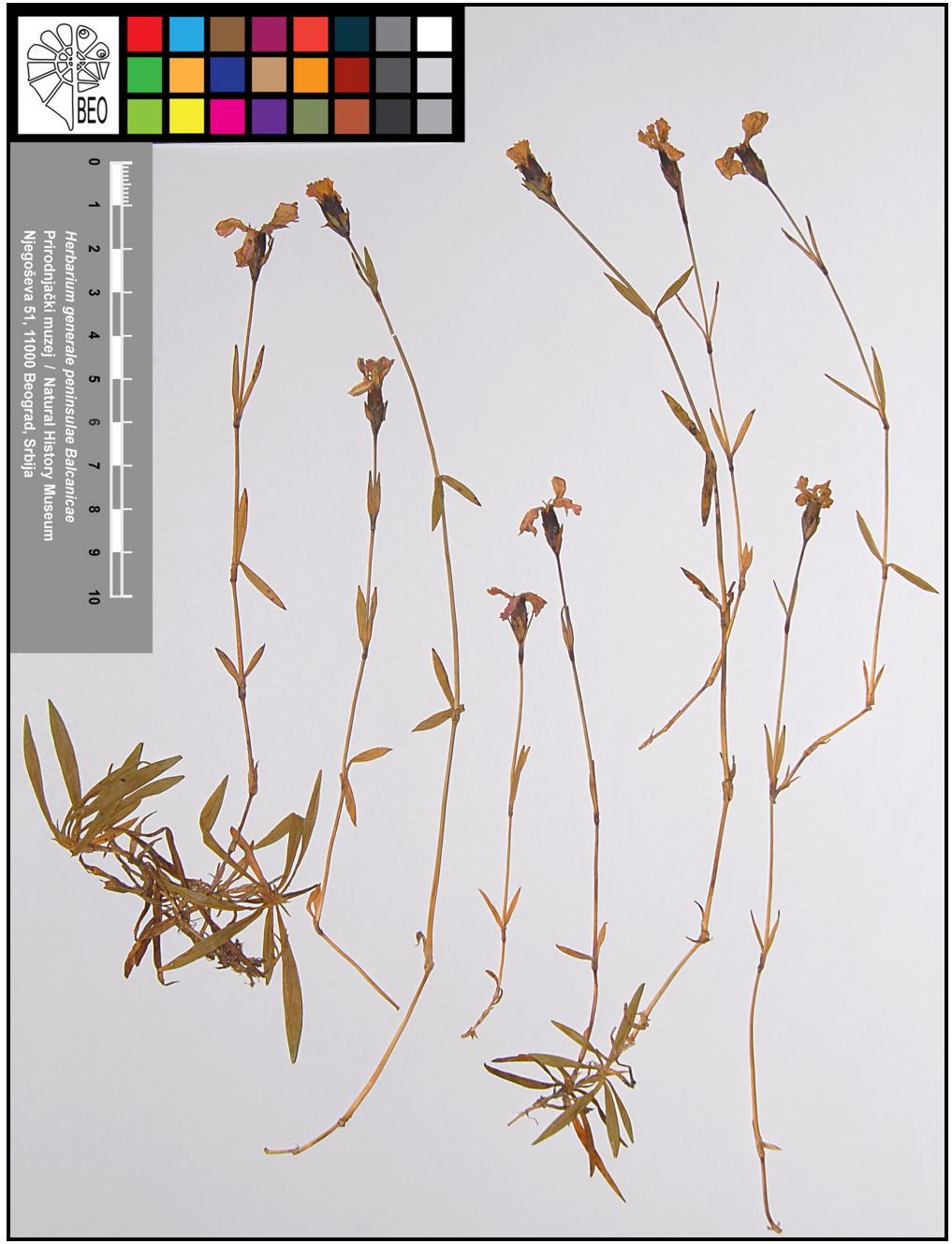

Fig. 15. - Dianthus lakusicii (Wraber) Niketić (Metohija, Prokletije Mts, Mt Hajla, BEO 100039). 


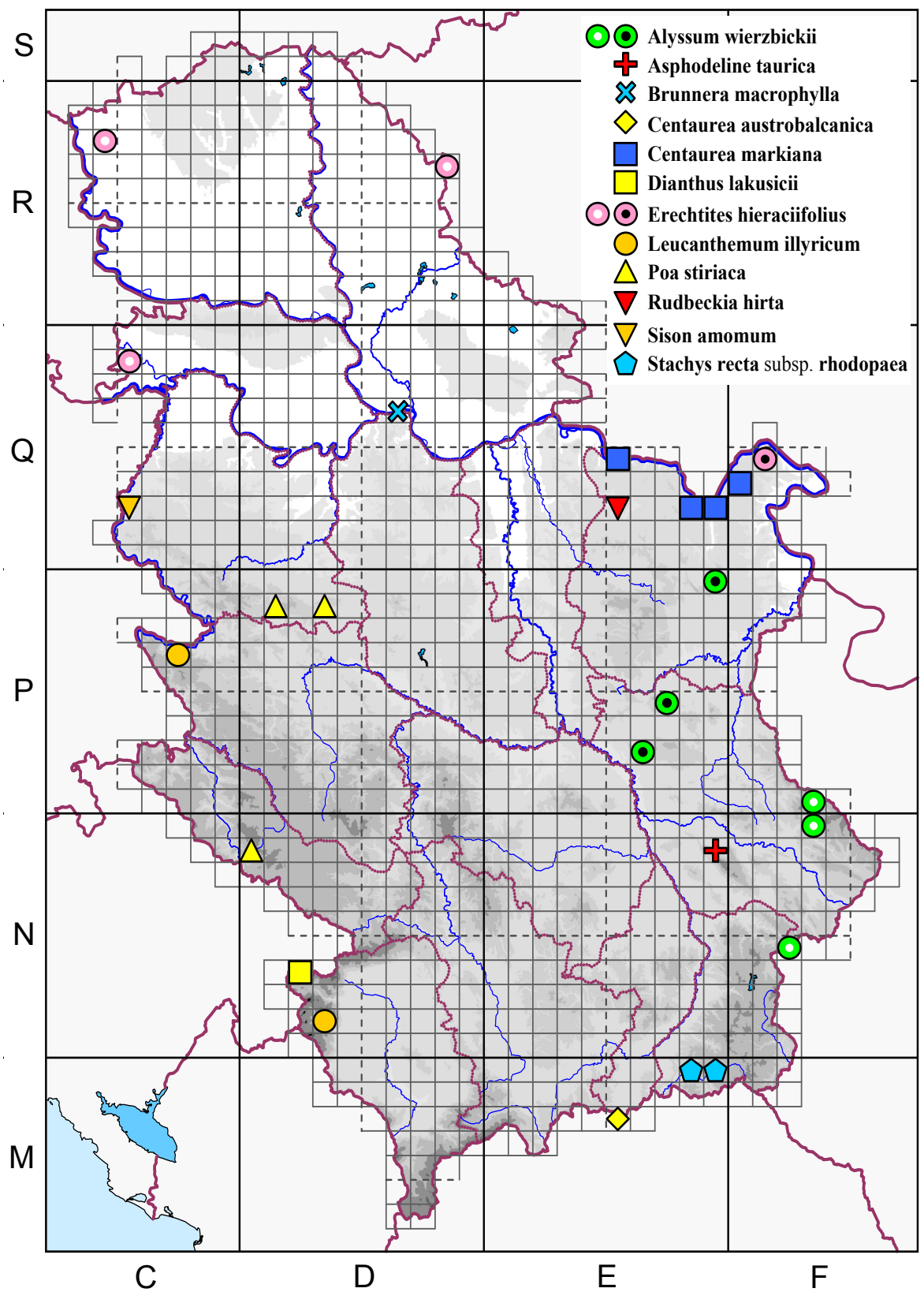

Fig. 16. - Distribution of some new taxa for the vascular flora of Serbia as well as Erechtites hieraciifolius, new for Vojvodina (small circles within symbol: white - new records; black - literature record).

Montenegro (Mt Hajla). After that it was proposed for protection under The Rulebook on the proclamation and protection of strictly protected and protected wild species of plants, animals and fungi (Sl. glasnik RS 2010- 
2011) and the presence of this taxon was reported for Serbia and Kosovo and Metohija in several publications (Ferakova et al. 2011, Amidžić et al. 2013, Tomović et al. 2014, Vuksanović 2016, Gavrilović et al. 2017), but without a specific locality, citation of data sources or any other information. Therefore, all of the above reports can be considered as preliminary. Area of occupancy was estimated at about $1 \mathrm{~km}^{2}$ and subpopulation size at more than 5000 mature individuals. It was found in subalpine belt in carbonate rocky pastures and in the zone of Pinus mugo Turra.

\section{First record:}

Metohija, Mts Prokletije, Mt Hajla, 1800-2400 m, limestone, rocky pastures, MGRS 34T DN23, coll. M. Niketić 03-Sep-1997, det. M. Niketić (BEO 100039) (Figs 15-16).

A new species for the flora of Serbia.

M. Niketić

\section{EUPHORBIACEAE}

Euphorbia glareosa Pall. ex M. Bieb., Fl. Taur.-Caucas. 1: 373 (1808).

$\equiv$ Euphorbia nicaeensis subsp. glareosa (Pall. ex M. Bieb.) Radcl.-Sm., Repert. Spec. Nov. Regni Veg. 79: 55 (1968).

During floristic investigation in Mt Rujan Planina in S Serbia an interesting plant from E. nicaeensis group was found on rocky and eroded areas around the quarry (BEO 100005) (Fig. 17A-B). After revision of herbarium material from Serbia and neighbouring countries, it was identified as E. glareosa Pall. ex M. Bieb. Although the same taxon has already been reported in the Flora of SR Serbia (Janković \& Nikolić 1972) and many other sources, everything previously mentioned for this taxon actually refers to E. pannonica Host (= E. glareosa var. lasiocarpa Boiss.) (Fig. 17C), which is much larger plant, with stiff and thicker, relatively wider leaves, with 3-5(7) prominent basal nerves and larger number of rays. According to Geltman $(2015,2020)$ and Pahlevani (2017) E. pannonica is a Panonnian-East Submediterranean plant (described from Pannonian Austria) which grows most often in steppe or steppe-like grasslands on different substrates, while E. glareosa is an Oriental-PontianEast Submediterranean plant (described from Georgia and absent from the Pannonian Basin) and more associated with rocky substrate. The occurrence of both species in sympatry was observed in E Mediterranean (Transcaucasia, North Anatolia and E part of the Balkan Peninsula). In the current World Checklist (Govaerts et al. 2020) E. pannonica is incorrectly not listed for the Pannonian countries, including Serbia. According to the same source E. glareosa is also absent from that region and reaches out to the west to Bulgaria, while according to Geltman (2015) it also reaches to Dobruja in E Romania. The new locality of the species on Mt Rujan in S 
Serbia is currently the westernmost point in the species range. Its presence can also be expected in Kosovo and Metohija, as well as in North Macedonia. Since all previous data on the presence in Serbia were erroneous and correspond to E. pannonica, the new record from Mt Rujan Planina at the same time represents a new addition to the flora of Serbia.

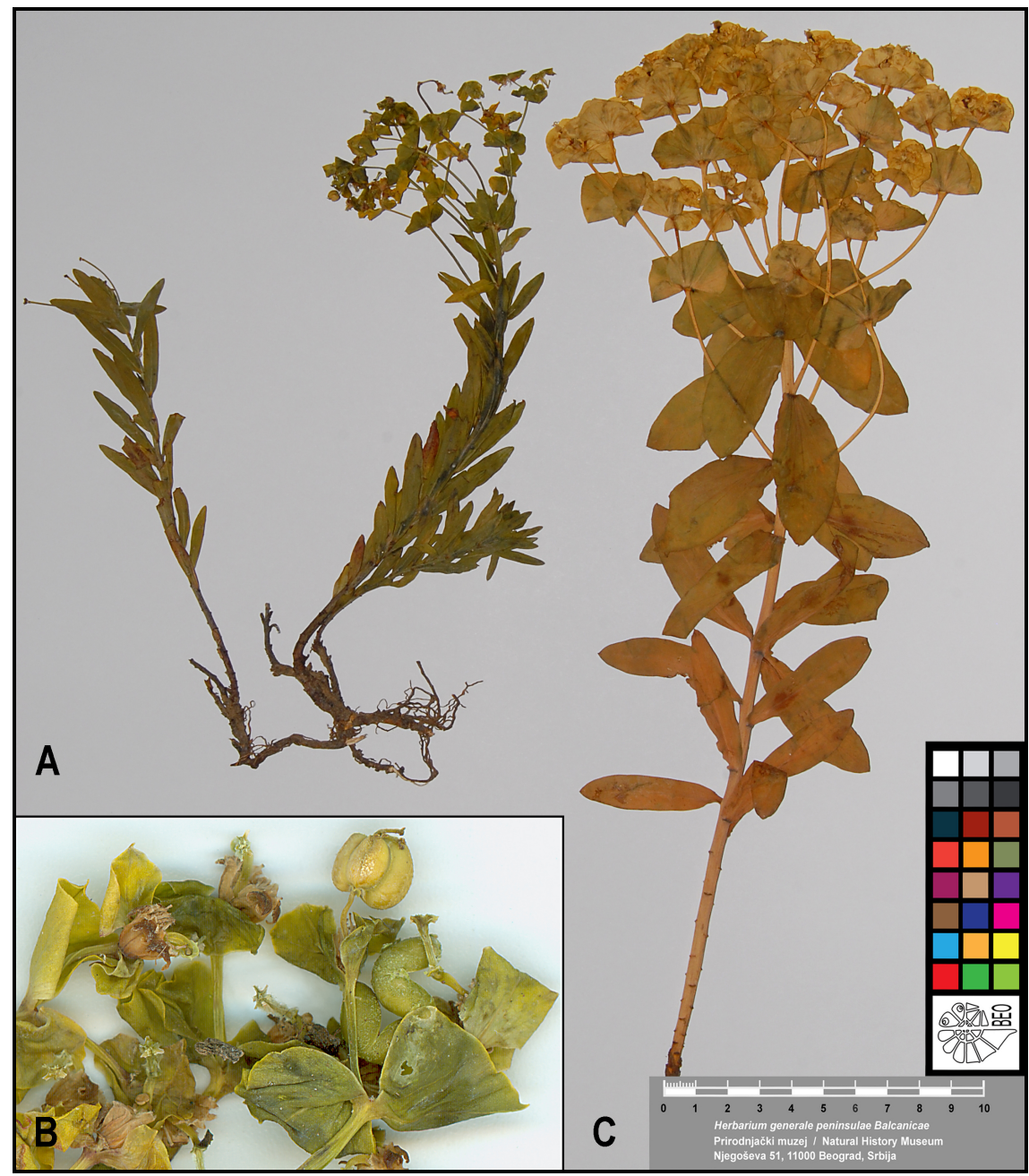

Fig. 17. - A-B Euphorbia glareosa Pall. ex M. Bieb. (S Serbia, Mt Rujan Planina BEO 100005); C E. pannonica (Vojvodina, Srem, Banstol, BEO 37263).

First record:

S Serbia, Mt Rujan Planina, Cer, quarry, limestone, eroded areas around the quarry, MGRS 34T EM57, coll. B. Zlatković 04-Jun-2020, det. B. Zlatković, M. Niketić (BEO 100005) (Figs 17A, 34).

A new species for the flora of Serbia. 


\section{LAMIACEAE (LABIATAE)}

Stachys recta subsp. nitens (Janka) Ciocârlan, Fl. Il. României: 180 (1990).

[Beldie, Fl. Rom. Determ. Ilust. Pl. Vasc.2: 75 (1979), comb. inval.]

= Stachys nitens Janka, Linnaea 30: 597 (1860) [basionym] $\equiv$ Stachys recta var. nitens (Janka) Chrtek f., Folia Geobot. Phytotax. 27: 182 (1992).

= Stachys recta var. ramosissima Rochel ex Griseb. \& Schenk, Arch. Naturgesch. 18(1): 330 (1852); Hayek, Repert. Spec. Nov. Regni Veg. Beih. 30(2): 294 (1929) [subsp. subcrenata], non sensu Diklić, Fl. Srbije 6: 427 (1974).

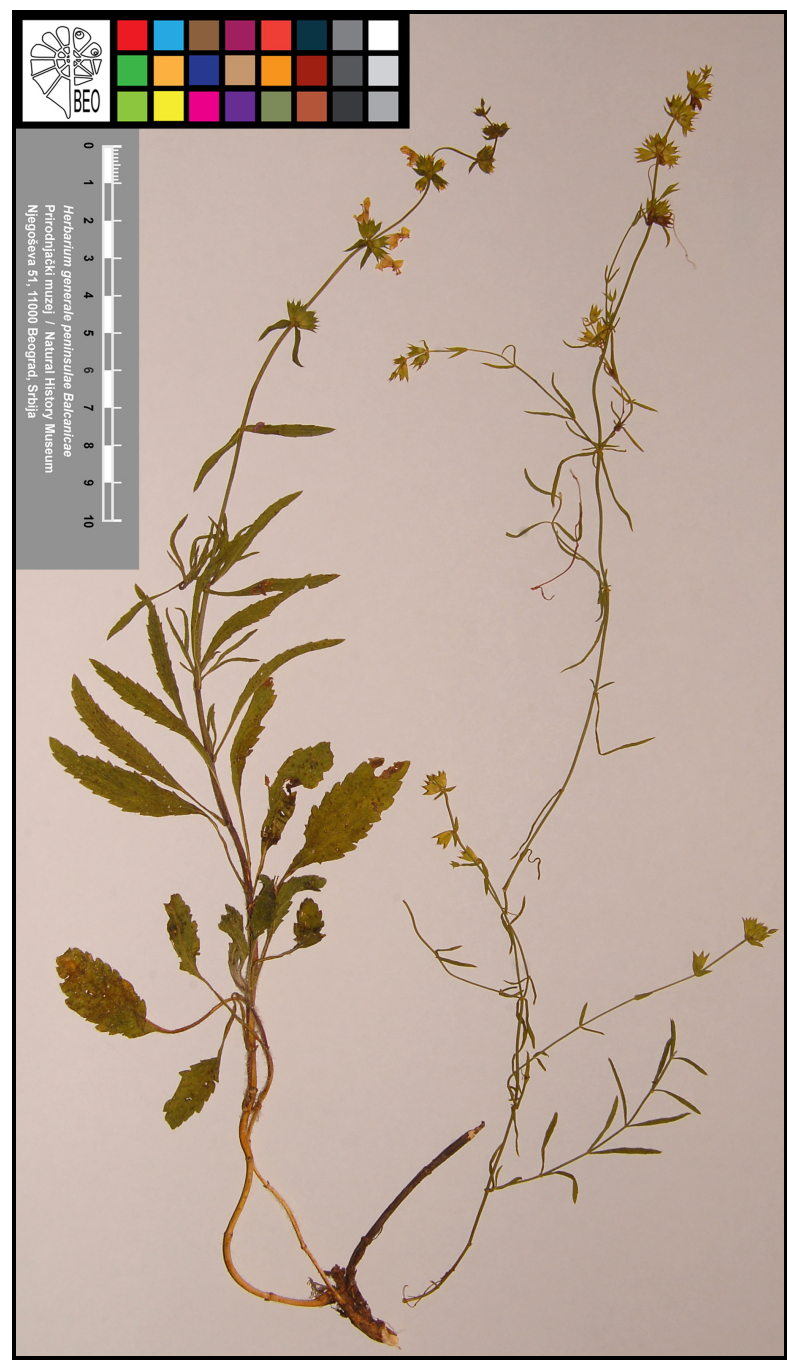

Fig. 18. - Stachys recta subsp. nitens (Janka) Ciocârlan (NE Serbia, Mt Veliki Greben, Gradašnica cave - Avramica, BEO 100037). 
Independently described as a variety (Grisebach \& Schenk 1852) and a species (Janka 1860) from SW Romania, near the Serbian border, the plant was also mentioned for the eastern parts of Romania, near the Black Sea coast (Răvărut 1960, Beldie 1979). In our opinion the populations of this plant are morphologically and ecologically well defined and deserve the rank of a subspecies. It differs from the type subspecies by its glabrescent habitus, thiny and fragile branches, narrow leaves, as well as by longer calyx teeth. For the flora of the Balkan Peninsula it was also recorded in Serbia and Bosnia and Hercegovina (Hayek 1929) (as S. recta var. ramosissima) without specific localities, but since this author emphasizes that the stems and calyx are hairy, these data probably do not refer to $S$. recta subsp. nitens. It was later mentioned under the same name for $\mathrm{S}$ Serbia (Diklić 1974), but this record has to be treated as erroneous. In the same publication Diklić also mentioned possibly correct location of this taxon (Mt Miroč in NW Serbia), but under the misapplied name "S. recta var. fragilis". Niketić (2005) preliminary recorded this subspecies (as $S$. nitens) for NW (Đerdap Gorge and Podvrška: Ms Velika Čuka) and E (Mt Suva Planina and Jerma Gorge) Serbia. However, the specimens from E Serbia do not belong to this subspecies. Since all previous data for Serbia were erroneous or preliminary, the taxon should be considered as new for the flora. Its correct distribution in Serbia is shown in Fig. 34.

\section{First records:}

NE Serbia, Đerdap Gorge, between Tekija and Kovilovski stream, MGRS 34T FQ14, coll. V. Nikolić 07-Aug-1966, det. N. Diklić (sub $S$. recta subsp. labiosa var. glabrata), rev. M. Niketić 14-Feb-2004 (s.n. BEO).

NE Serbia, Đerdap Gorge, Tekija, peat, MGRS 34T FQ14, coll. V. Nikolić 03-Oct-1968, det. N. Diklić (sub S. recta subsp. recta), rev. M. Niketić 14-Feb-2004 (s.n. BEO).

NE Serbia, Donji Milanovac, Mt Veliki Greben, Carpinus orientalis underbrush, MGRS 34T EQ92, coll. N. Diklić 31-Jul-1964 (sub S. recta subsp. subcrenata var. hyssopifolia subvar. fragilis), rev. M. Niketić 01-Feb-2007 (s.n. BEO).

NE Serbia, Đerdap Gorge, Donji Milanovac, Porečka river - Velika Gradišnica river, MGRS 34T EQ92, coll. V. Nikolić, N. Diklić 04-Aug1966, det. M. Niketić (s.n. BEO).

NE Serbia, Đerdap Gorge, Mali Štrbac peak, rocky grounds along the ridge, MGRS 34T FQ04, coll. V. Nikolić, N. Diklić 18-Jun-1977, det. M. Niketić (s.n. BEO). 


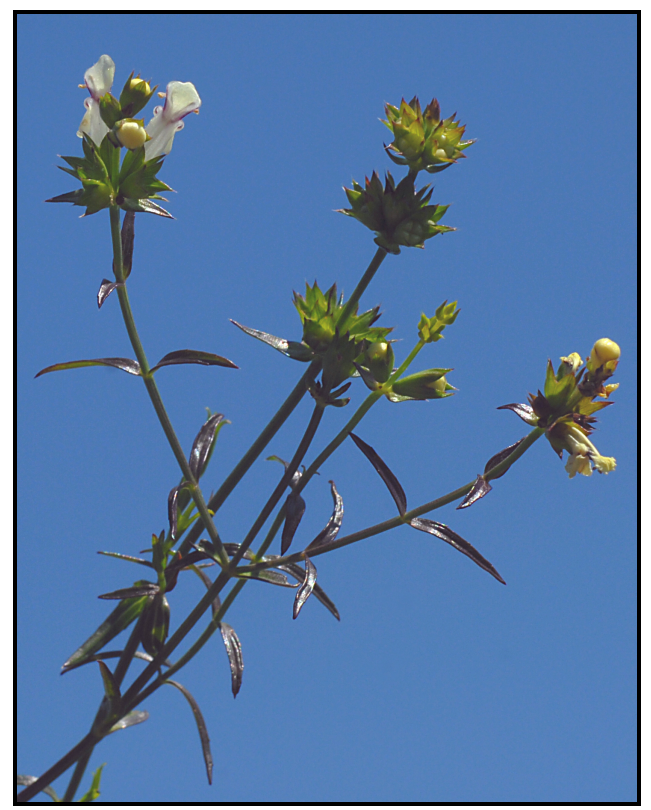

Fig. 19. - Stachys recta subsp. nitens (Janka) Ciocârlan (NE Serbia, Mt Veliki Greben, Gradašnica cave) (photo M. Niketić).

NE Srbija: Mt Miroč, Podvrška, Ms Velika Čuka; 370 m; limestone; rock crevices. MGRS 34T 34T EQ92FQ13, coll. M. Niketić, V. Stevanović, G. Tomović 15-Jun-1998, det. M. Niketić (100040 BEO).

NE Serbia: Mt Veliki Greben, Gradašnica cave - Avramica; 350 m; limestone; rock crevices. MGRS 34T 34T EQ92, coll. M. Niketić, G. Tomović 14-Jun-2009, det. M. Niketić (BEO 100037) (Figs 18-19).

NE Serbia: Mt Veliki Greben, Gradašnica cave; 350 m; limestone; rock crevices. MGRS 34T 34T EQ92, coll. M. Niketić 26-Jul-2010, det. M. Niketić (BEO 100038).

NE Serbia: Đerdap Gorge, Tekija, Misija; $150 \mathrm{~m}$; serpentinite; steppe vegetation. MGRS 34T 34T FQ14, coll. M. Niketić 18-Sep-2018, det. M. Niketić (BEO 100034).

NE Serbia: Đerdap Gorge, Tekija, Džervin Kamen; 300 m; limestone; rock crevices. MGRS 34T 34T FQ15, coll. M. Niketić 17-Sep-2018, det. M. Niketić (BEO 100035).

NE Serbia: Negotinska Krajina, Vratna Gorge; 250 m; limestone; rock crevices. MGRS 34T 34T FQ01, coll. M. Niketić 14-Nov-2018, det. M. Niketić (BEO 100036).

A new subspecies for the flora of Serbia. 
Stachys recta subsp. rhodopaea (Velen.) Chrtek f., Folia Geobot. Phytotax. 27: 182 (1992).

三Stachys fragilis var. rhodopaea Velen., Fl. Bulg.: 456 (1891) [basionym] $\equiv$ Stachys recta [subsp. subcrenata var. ramosissima] subvar. rhodopaea (Velen.) Hayek, Repert. Spec. Nov. Regni Veg. Beih. 30(2): 294 (1929).

Due to the thiny and fragile branches, narrow leaves, and longer calyx teeth, this subspecies was very often confused with previous subspecies, $S$.

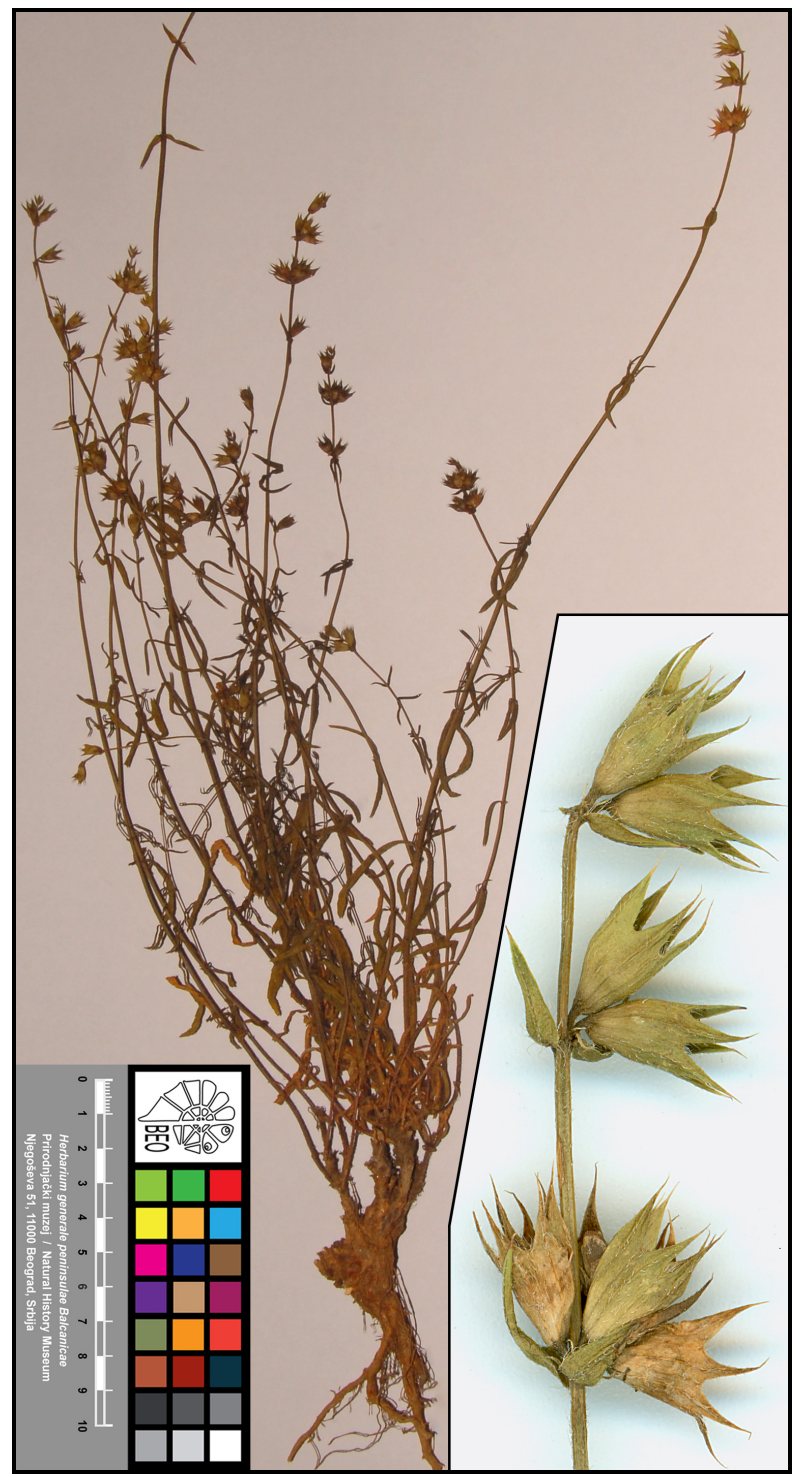

Fig. 20. - Stachys recta subsp. rhodopaea (Velen.) Chrtek f. (SE Serbia, Pčinja Gorge, Šajince- Trgovište, coll. V. Nikolić, N. Diklić 14-Jul-1972, BEO s.n.). 
recta subsp. nitens (Janka) Ciocârlan (Hayek 1929, Diklić 1974). It differs from the mentioned subspecies primarily by its conspicuously hairy habitus. It was described from Bulgaria, and also known from North Macedonia (Chrtek, 1992). Preliminary recorded from SE Serbia (Pčinja Gorge) in Niketić (2005).

\section{First records:}

SE Serbia, Pčinja Gorge, between Trgovište and Radovnica, rocks, MGRS 34T EM99, coll. V. Nikolić, N. Diklić 13-Jul-1972, det. N. Diklić (sub $S$. recta subsp. subcrenata subvar. fragilis), rev. M. Niketić 01-Feb-2007 (s.n. BEO).

SE Serbia, Pčinja Gorge, between Šajince and Trgovište, rocks by the road, MGRS 34T EM89, coll. V. Nikolić, N. Diklić 14-Jul-1972, det. N. Diklić (sub S. recta subsp. subcrenata subvar. fragilis), rev. M. Niketić 01-Feb-2007 (s.n. BEO) (Fig. 20).

SE Serbia, Pčinja Gorge, Trgovište, Vražji Kamen, MGRS 34T EM89, coll. M. Niketić, V. Vladimirov 07-Jul-2014, det. M. Niketić (BEO 100033).

A new subspecies for the flora of Serbia.

M. Niketić

\section{SCROPHULARIACEAE}

Verbascum dieckianum Borbás \& Degen in Degen, Magyar Bot. Lapok 4: 82 (1905).

This C Balkan endemic species of mullein was described from North Macedonia near Skopje (Degen 1905), and was also reported from N Greece and Bulgaria (Marhold 2011+). In the region of Mt Rujan Planina in S Serbia it was also found in dry grasslands on different type of substrate (Fig. 34). The plant can be easely recognized by its brown and membranous bracts in maturity. Population size was estimated to more than 1000 reproductive individuals that are widespread within the area of Mt Rujan Planina. It was previously preliminary enounced for the same area by Niketić (2000).

First records:

S Serbia, Mt Rujan Planina, Orljak peak, limestone, MGRS 34T EM67, coll. M. Niketić 15-Apr-1991, det. M. Niketić (BEO 100020).

S Serbia, Mt Rujan Planina, Mali Orljak peak, from the pass to the top, silicate, forest and steppe-like pastures, 680-710 m, MGRS 34T EM57, coll. M. Niketić, G. Tomović 15-Aug-2010, det. M. Niketić (BEO 100021) (Fig. 21).

S Serbia, Mt Rujan Planina, Mamince village, MGRS 34T EM58, coll. M. Niketić 30-May-1991, det. M. Niketić (BEO 100022). 


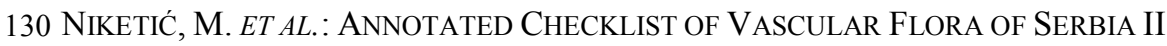

A new species for the flora of Serbia.

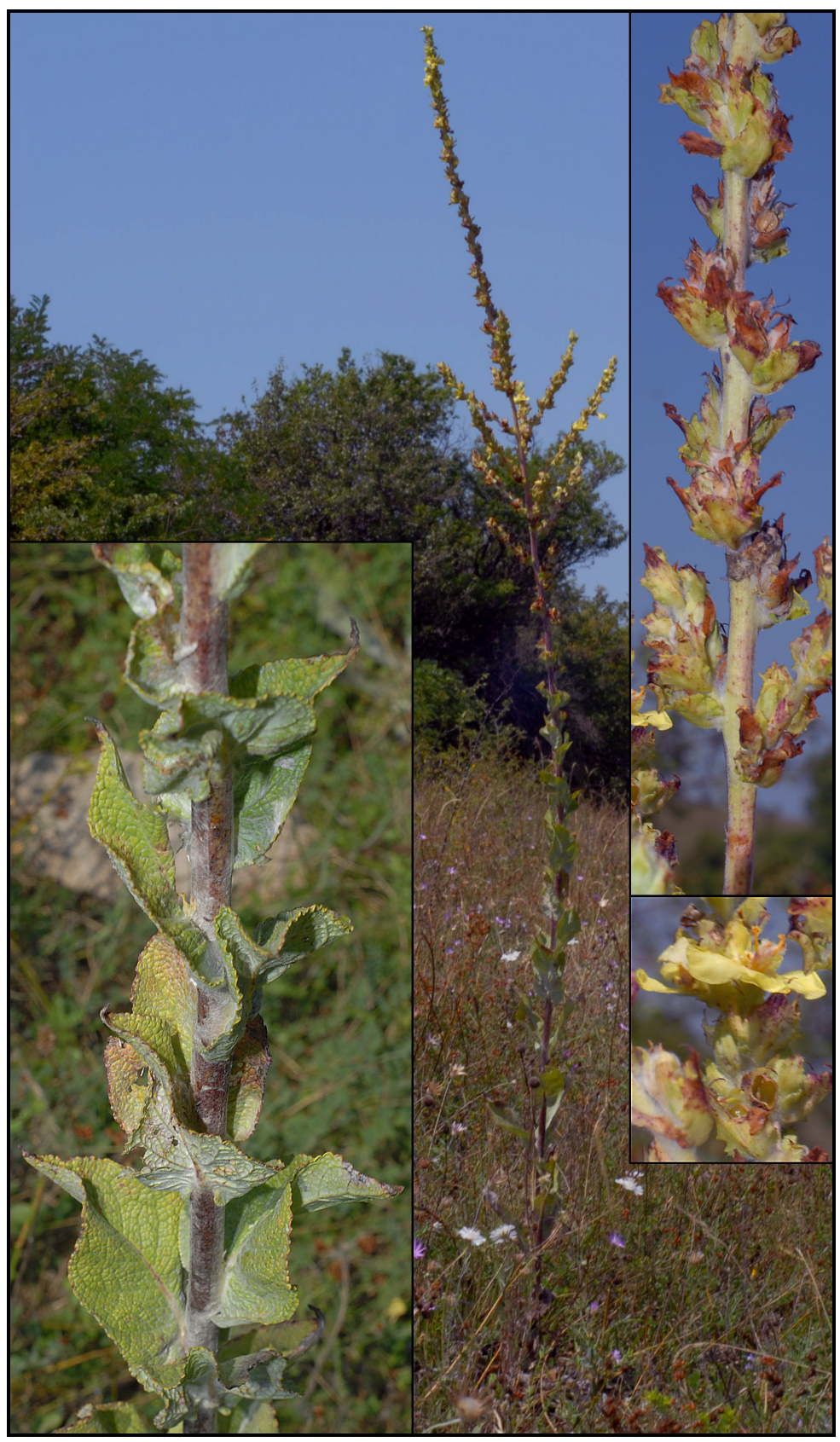

Fig. 21. - Verbascum dieckianum Borbás \& Degen (S Serbia, Mt Rujan Planina, Mali Orljak) (photo M. Niketić). 


\section{New and confirmed taxa for the flora of administrative units}

\section{LILIOPSIDA}

\section{CYPERACEAE}

Cyperus odoratus L., Sp. Pl. 46 (1753).

Since its first record in SE Europe in the Danube valley in Bulgaria (as "C. strigosus" Tzonev et al. 2003), this North and South American species was expected to be found upstream along the river Danube and its tributaries. This proved to be correct with the first records in Serbia originating from habitats along the river Danube in the vicinity of Dubovac, Kovin (as "C. strigosus" Stevanović et al. 2004, 2005), Labudovo Okno [http://iasv. dbe.pmf.uns.ac.rs/index.php] and Pančevo (Perić \& Rilak 2017). According to Verloove (2014) earlier records of C. strigosus from Bulgaria and Serbia are erroneous and refer to $C$. odoratus. Our field investigations confirm identity of this species in Serbia as $C$. odoratus and its further spread to the west. We found this species at four localities along the mouth of the river Drina, which are the first data for this species for the flora of Serbia proper (it was previously published in abstract form, Stanković et al. 2018). Also, additional data for two localities in Vojvodina (vicinity of Kovilj and Gardinovci) confirm its upstream spread along the Danube (Fig. 34).

First records for Vojvodina province:

NW Serbia, Bogatić, Crna Bara, Parašnica, along the river Drina, $75 \mathrm{~m}$, 19.368975 E, 44.882930 N, MGRS 34T UTM CQ77, coll. M. Stanković det. R. Perić 08-Aug-2017 (s.n. collection of Zasavica Special Nature Reserve).

NW Serbia, Zvornik, Radalj, Luke, along the Radalj river, $193 \mathrm{~m}$, 19.19253 E, 44.40794 N, MGRS 34T UTM CQ51, coll. M. Stanković det. R. Perić 30-Sep-2017 (s.n. collection of Zasavica Special Nature Reserve).

NW Serbia, Velika Reka, along the Velika Reka river, 164 m, 19.23906 E, 44.27736 N, MGRS 34T UTM CQ50, coll. et det. M. Stanković 21Sep-2016 (s.n. Private herbarium collection of M. Stanković).

NW Serbia, Ljubovija, Gračanica, along the river Gračanička, about $200 \mathrm{~m}$ from the rivermouth, $176 \mathrm{~m}$, MGRS 34T UTM CQ69, coll. et det. M. Stanković 23-Sep-2016 (s.n. Private herbarium collection of M. Stanković) (Fig. 22).

NW Serbia, Ljubovija, Donja Ljubovidja,along the river Ljubovidja, $225 \mathrm{~m}, 19.55889 \mathrm{E}, 44.23583 \mathrm{~N}$, MGRS 34T UTM CQ79, coll. et det. M. Stanković 22-Sep-2016 (s.n. Private herbarium collection of M. Stanković). 


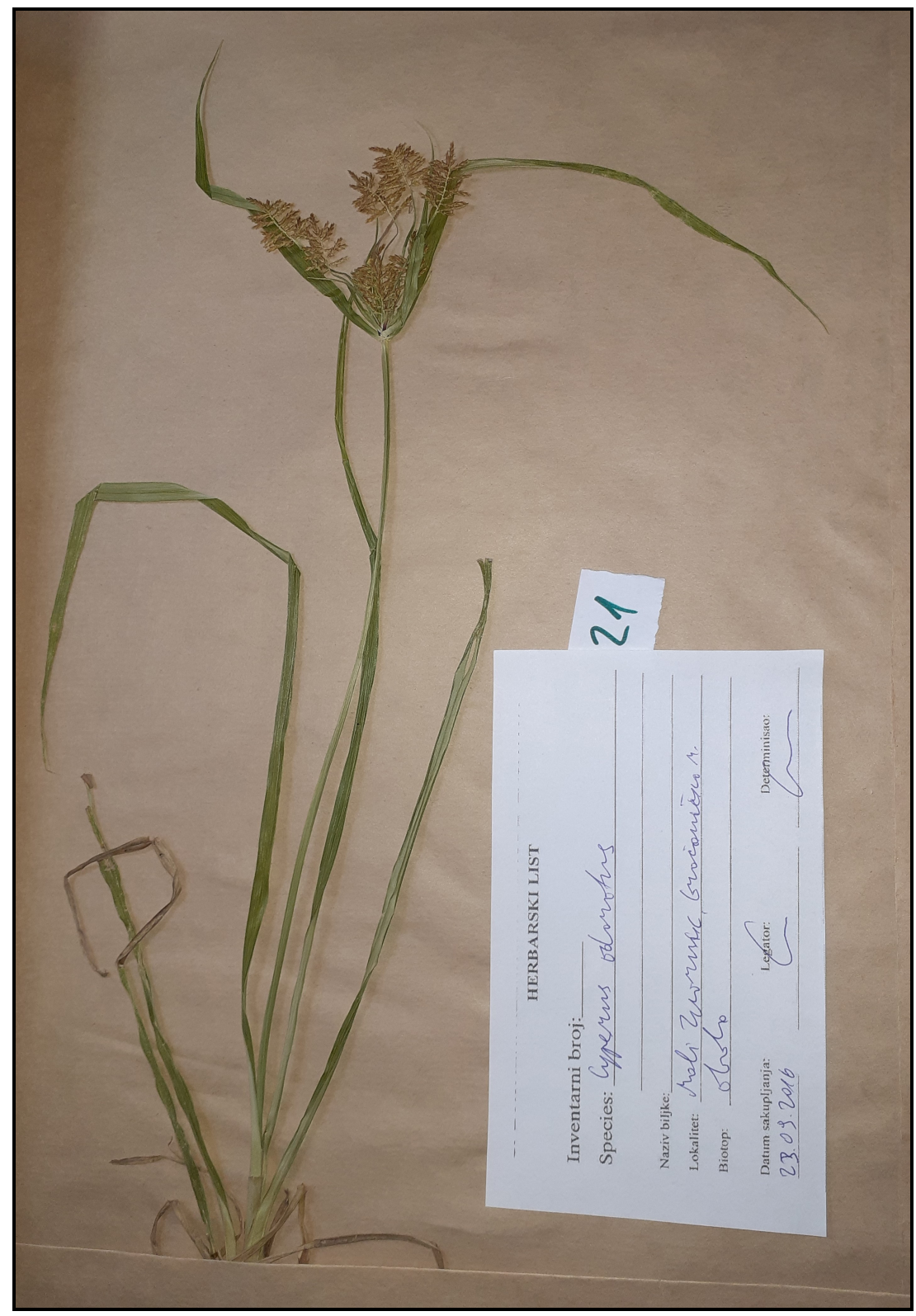

Fig. 22. - Cyperus odoratus L. (NW Serbia, Ljubovija, Gračanica, s.n. collection of Zasavica Special Nature Reserve).

Additional records for Vojvodina province:

Bačka, Gardinovci, Gardinovački liman, 73 m, 20.1301 E, 45.19549 N, MGRS 34T UTM DR30, coll. et det. R. Perić 13-Sep-2011 (s.n. PZZP). 
Bačka, Kovilj, Koviljski rit, Golić, along Stari Dunav oxbow, 75 m, 20.02553 E, 45.20725 N, MGRS 34T UTM DR20, coll. et det. R. Perić 23-Sep-2009 (s.n. PZZP).

A new allochthonous species for the flora of Serbia proper.

R. Perić, M. Stanković, S. Djordjević, M. Bartula, S. Djordjević-Milošević

\section{IRIDACEAE}

Crocus tommasinianus Herb., J. Hort. Soc. London 2: 273 (1847)

An indirect indications of the presence of this species in the flora of Serbia were first presented by Pančić (1856) and Janka (1868) (see on page 89 ) and also through the invalid name of one herbarium specimen $-C$. serbicus Kern. ex Maw (1881). The first reliable data on the distribution of the species C. tommasinianus Herb. in Serbia comes from Pančić (1884) for Sokolovik near Zaječar. This species was also mentioned for Mt Kopaonik (Maw 1886, sub C. serbicus). Later, the species was found in Serbia in many other localities south of the Sava and Danube rivers (Randjelović et al. 1990).

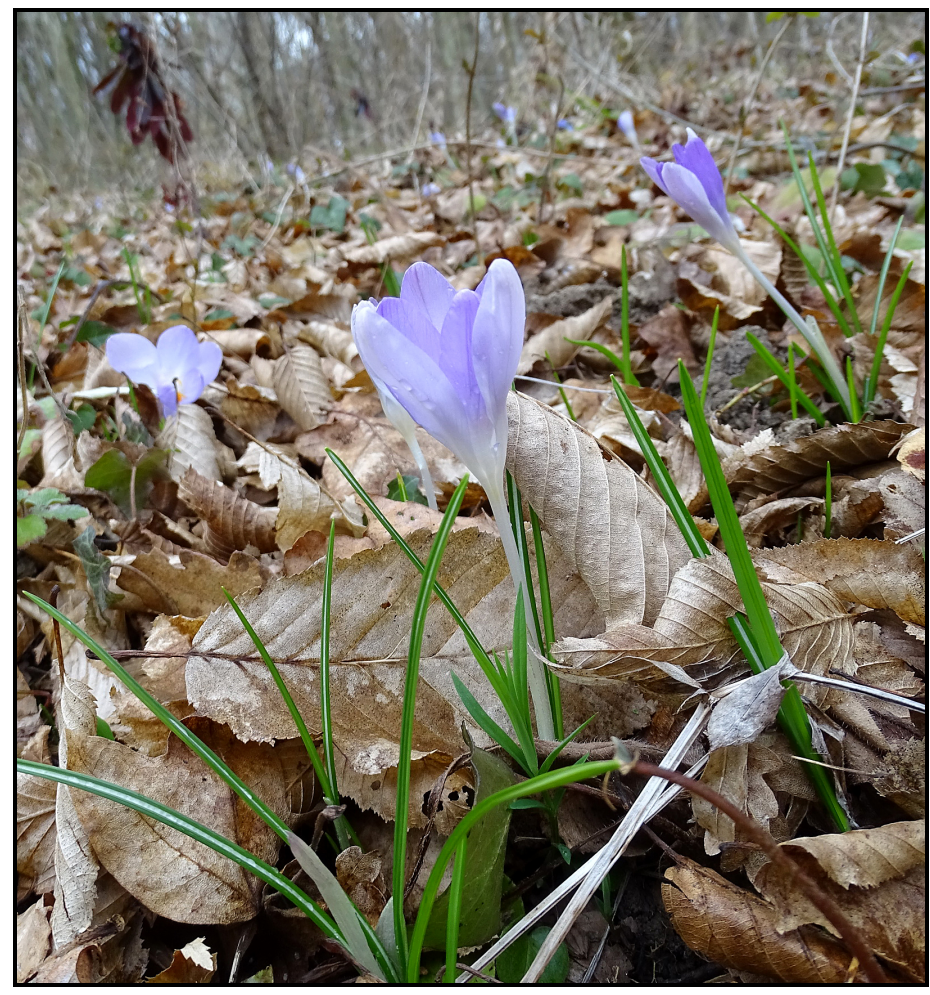

Fig. 23. - Crocus tommasinianus Herb. (Srem, Fruška Gora, near village Lug) (photo V. Randjelović). 
The area of C. tommasinianus includes Croatia, Montenegro, Bosnia and Herzegovina, Serbia, Bulgaria, and North Macedonia (Pulević 1977, Randjelović et al. 1990). According to Barina et al. (2018) the only record for Albania (Meyer 2011) is doubtful. In the Pannonian plain, $C$. tommasinianus are known as allochthonous species from three localities in Hungary (Bartha \& Király 2015): village Gyulaj in Tolna County (Jávorka 1964, Priszter 1964a,b, Suranyi et al. 2010), Villanyi hills in Baranya County (Kevey 1990, Dénes 2000) and Soproni hills in Győr-MosonSopron County (Király et al. 2009). It is also introduced as horticultural plant in UK, Belgium, Netherland, Germany and USA (POWO 2020).

A substantial population of C. tommasinianus was found in a beech forest not far from the village of Lug on Mt Fruška Gora. Area of occupancy was estimated at about $200 \mathrm{~m}^{2}$ and subpopulation size at more than 1000 mature individuals. It is the first finding of this species for Vojvodina and the possibility that species presence in Mt Fruška Gora is due to anthropogenic factors can not be excluded.

First record for Vojvodina province:

Srem, Fruška Gora, near village Lug, beech forest, 228 m, MGRS 34T CR80, 19.5309 E, 45.1647 N, coll. et det. D. Savić, V. Randjelović, 26Feb-2020 (HMN 14265) (Figs 23, 34).

A new species for the flora of Vojvodina province.

V. Randjelović, D. Savić

\section{ORCHIDACEAE}

Anacamptis laxiflora (Lam.) R. M. Bateman, Pridgeon \& M. W. Chase, Lindleyana 12(3): 120 (1997).

Knowledge of the distribution of this Atlantic-Submediterranean species in Serbia is not sufficient (Djordjević et al. 2018), bearing in mind that the taxon was cited in the literature only at the specific rank for the flora of Serbia, including two subspecies of Anacamptis (Orchis) palustris: elegans and palustris (Diklić 1976). Consequently, published data on the distribution of A. laxiflora cannot be considered with certainty and therefore there is a need for further confirmation of the presence of this taxon in Serbia. It is assumed that most of the published records actually refer to the species A. palustris, and primarily subspecies elegans. Recent research has confirmed that $A$. laxiflora grows in the area of S Serbia, in the vicinity of Preševo (Niketić et al. 2018a). According to the recent An annotated checklist of vascular flora of Serbia 1, its status in Kosovo and Metohija is marked as " $n$ ", which means that there is no reliable data, but that the presence is possible (Djordjević et al. 2018). Several authors have published data on the distribution of this taxon in Kosovo and Metohija, 


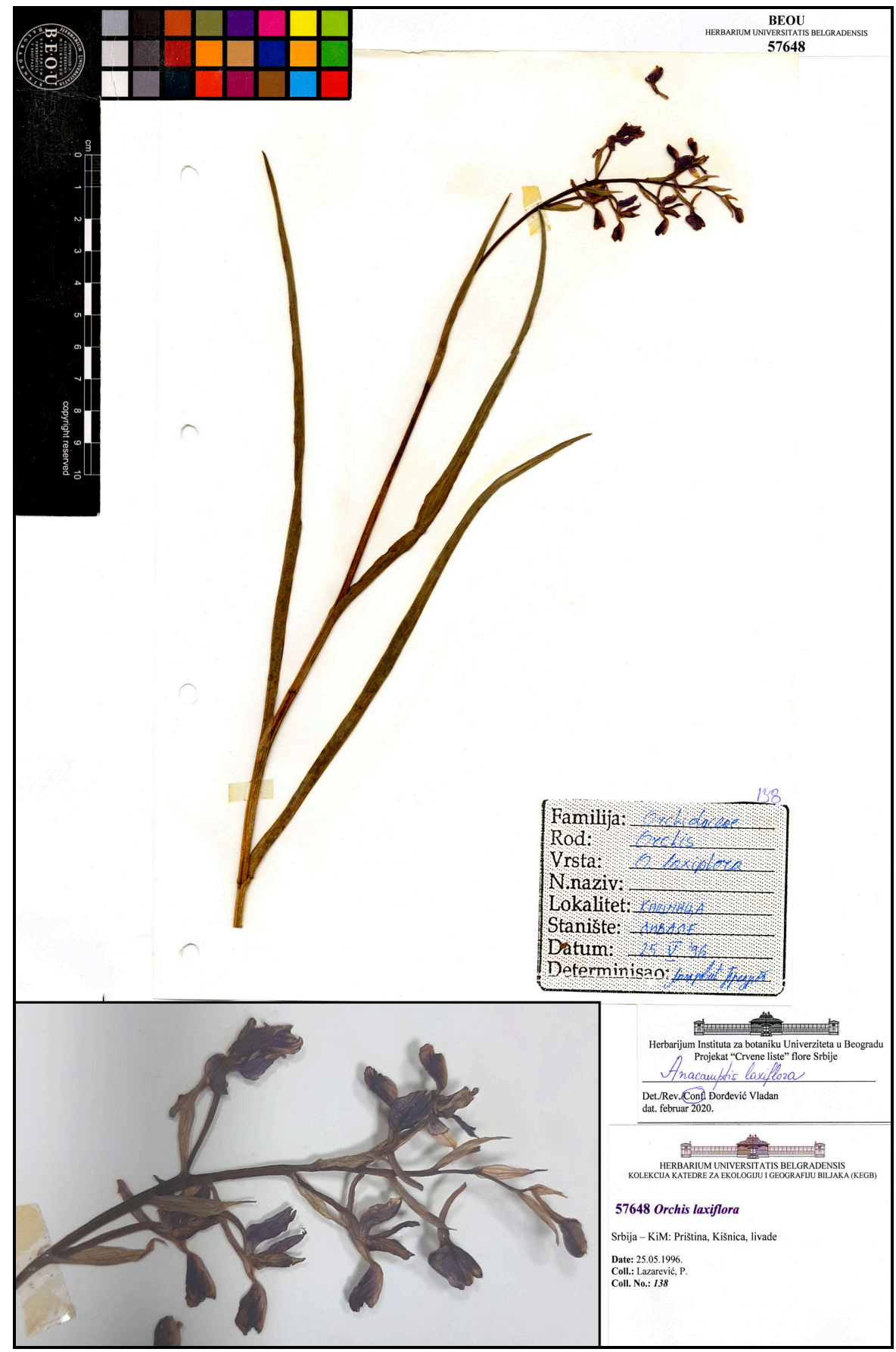

Fig. 24. - Anacamptis laxiflora (Lam.) R. M. Bateman (Kosovo, Priština, Kišnica, 57648 BEOU). 
such as: localities in the vicinity of Dečani and Uroševac (Nikolić et al. 1986); Prokletije Mts (Amidžić \& Panjković 2013); Kosovska Vitina (Kojić 2002); Šar Planina Mts (ZZPS 2011); Šar Planina Mts - Brezovica (Leute 1978); and Dečane - Rastavica and Uroševac - Grlica (Hundozi 1981). However, no herbarium material was found in the Herbarium of the Institute of Botany and Botanical Garden "Jevremovac", University of Belgrade (BEOU) and in the Herbarium of Natural History Museum in Belgrade (BEO), which confirms that these findings are still unreliable.

New record for Kosovo and Metohija province:

Kosovo, Priština, Kišnica, meadows, MGRS 34T EN11, coll. P.

Lazarević, det. P. Lazarević, V. Djordjević, 15-May-1996 (57648 BEOU) (Figs 24, 34).

Confirmed orchid species for the flora of Kosovo and Metohija, and the second confirmed record of this species in Serbia.

V. Djordjević, P. Lazarević

\section{POACEAE (GRAMINEAE)}

Bromus moesiacus Velen., Fl. Bulg.: 616 (1891).

For the flora of Serbia it was first published by Kožuharov et al. (1981) for Mt Kopaonik, locality Srebrnac. Afterwards, the same record was retrieved for the Kopaonik area by Lakušić (1996), but it was never confirmed in the field. We have found herbarium specimens from Kosovo and Metohija province along the Ibar river valley (Kamenica - Donje Jarinje, Srbovac), Kosovska Mitrovica and Šar Planina Mts. The supplemented distribution in Serbia is shown in Fig. 34.

First records for Kosovo and Metohija province:

Kosovo, Ibar river gorge, Kamenica village, sporadically to Donje Jarinje, mountain pastures, sporadically on dry embankments around the road, MGRS 34T DN78, coll. D. Prodanović, Z. Krivošej May2004, Jun-2005, det. Z. Krivošej (sub B. erectus subsp. fibrosus), rev. E. Kabaš 12-Mar-2020 (BEOU 17711).

Kosovo, Kosovska Mitrovica, Srbovac, MGRS 34T DN85, coll. B. Petković 10-Jul-1991 (sub B. fibrosus), rev. E. Kabaš 12-Mar-2020 (BEOU 60350).

Kosovo, Šar Planina Mts, Ostrovica, MGRS 34T DM97, coll. et det. V. Stevanović, S. Jovanović 20-Jul-1989 (sub B. erectus), rev. E. Kabaš 05-Feb-2020 (184/89 BEOU) (Fig. 25).

A new species for the flora of Kosovo and Metohija province. 


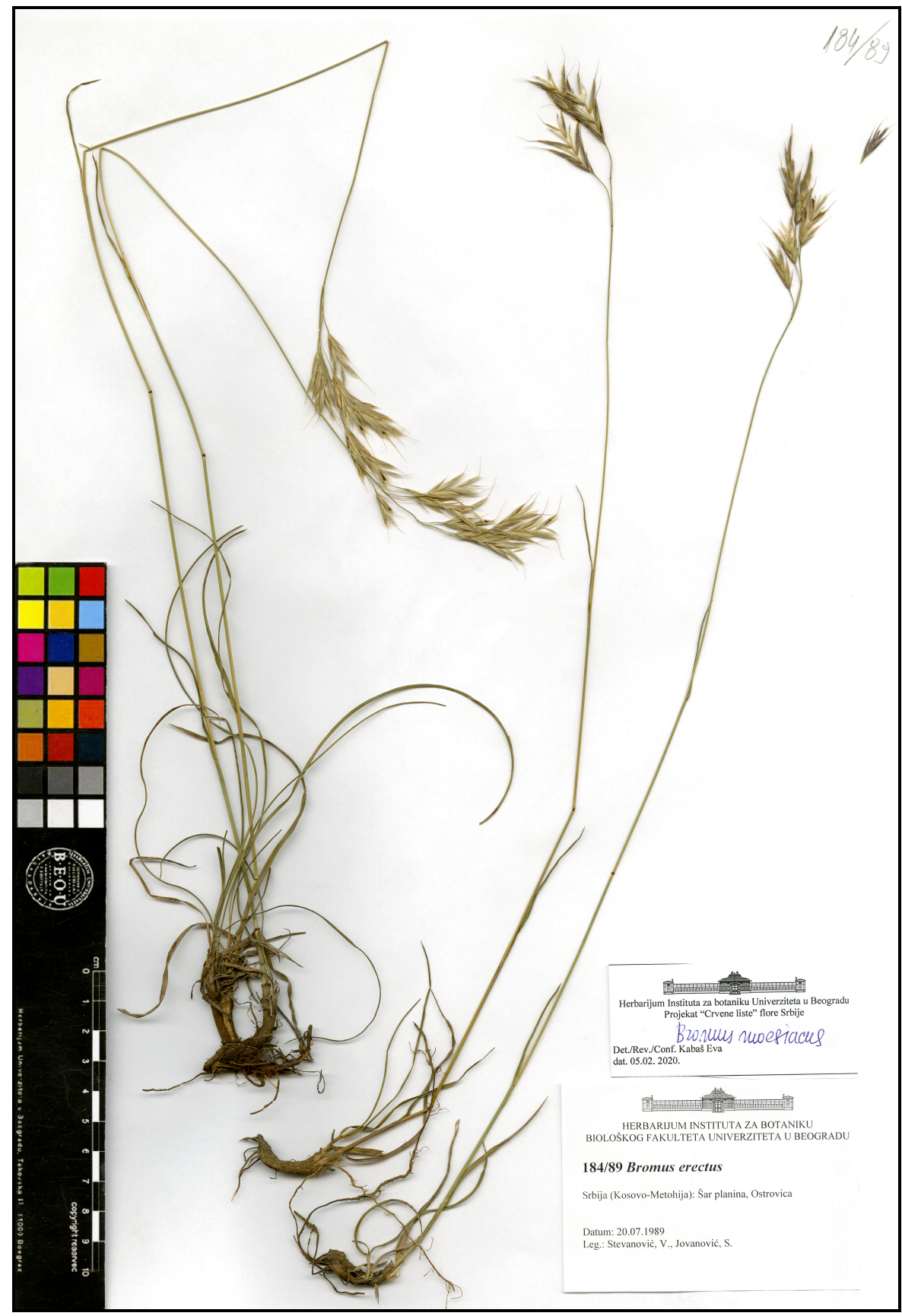

Fig. 25. - Bromus moesiacus Velen. (Kosovo, Šar Planina Mts, Ostrovica, 184/89 BEOU). 
Stipa tirsa Steven, Bull. Soc. Nat. Moscou 30(2): 115 (1857).

In the Flora of SR Serbia it was published for Mts Rtanj and Suva Planina, and Brestovačka Banja spa in Eastern and Northeastern Serbia (Vukićević 1976). It is also known from Vršački Breg in Vojvodina, where it was found in meadow steppe communities (Vučković 1991). Recently it was discovered in Central Serbia, on the Mt Kopaonik (Tomović et al. 2020) in ultramafic dry grassland steppe-like communities. Lakušić et al. (2018) refuted its presence in Vojvodina, however a herbarium sample from Mt Vršačke Planine (Široko Bilo) have been found (BUNS 00004340). Also new field records for Vojvodina were noted in the vicinity of Mesić (Mt Vršačke Planine).

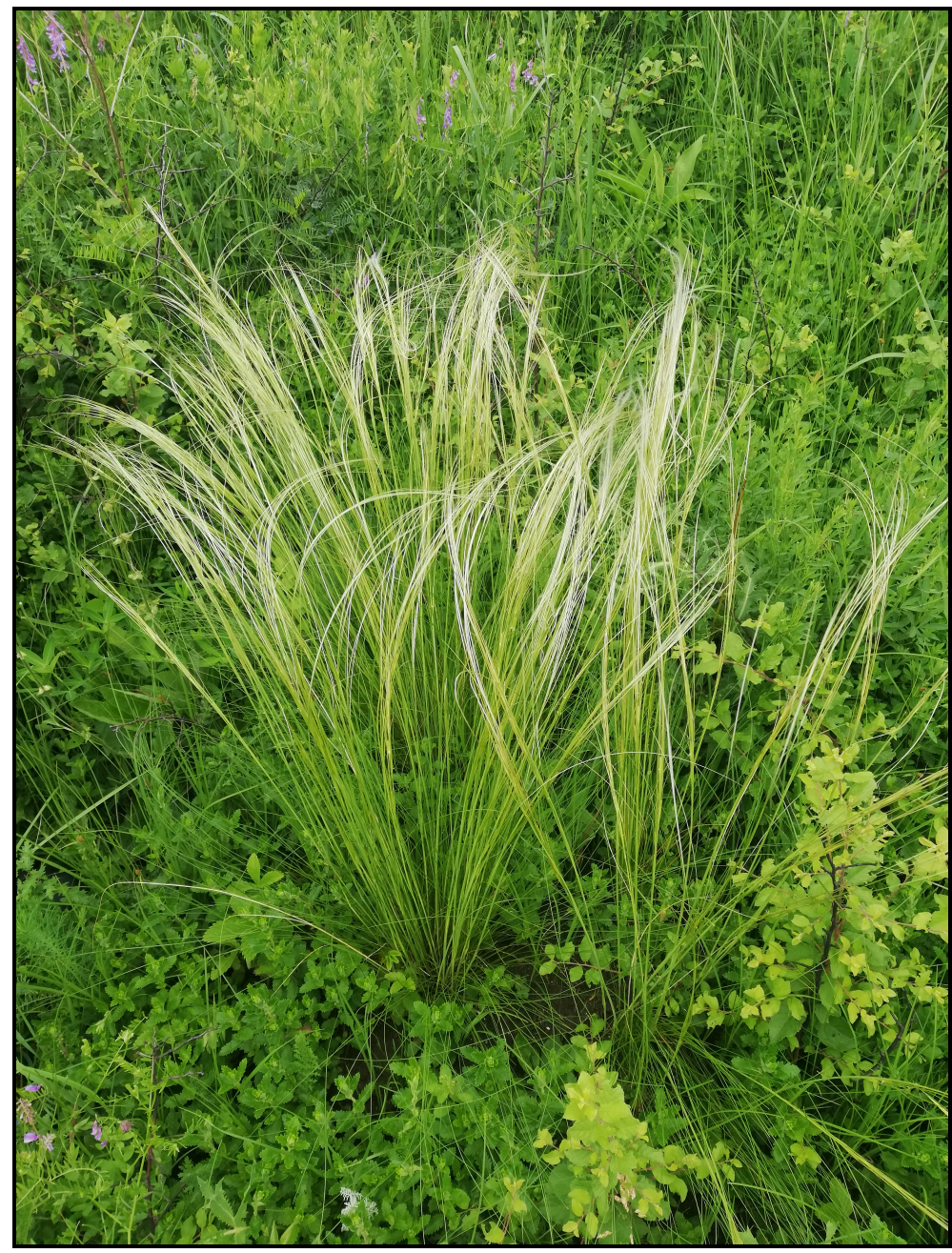

Fig. 26. - Stipa tirsa Steven (Vojvodina, Mt Vršačke Planine, in the vicinity of Mesić monastery) (photo E. Kabaš). 


\section{Unpublished record for Vojvodina province:}

Vojvodina, Mt Vršačke Planine, Široko Bilo, MGRS 34T EQ29, coll. et det. V. Matanović 04-Jun-1978 (sub S. joanis), rev. E. Kabaš 26-Mar2019 (00004340 BUNS).

New records for Vojvodina province:

Vojvodina, Mt Vršačke Planine, Manastir Mesić, 21.387646 E, 45. 103455 N, MGRS 34T EQ39, coll. et det. S. Vukojičić, E. Kabaš, P. Lazarević 30-May-2019 (BEOU 68137) (Fig. 26).

Vojvodina, Mt Vršačke Planine, Kuštilj, 21.363228 E, 45.091527 N, MGRS 34T EQ29, coll. et det. S. Vukojičić, E. Kabaš, P. Lazarević 30May-2019. (BEOU 68220).

Confirmed species for the flora of Vojvodina province (Fig. 34).

\section{E. Kabaš, S. Vukojičić, P. Lazarević}

\section{MAGNOLIOPSIDA}

ASTERACEAE (COMPOSITAE)

Carpesium abrotanoides L., Sp. P1. 860 (1753).

Since its first official record in the vicinity of Boljevci near Belgrade (Radulović 2002a, 2002b, also later published in Mataruga et al. 2016, Jarić et al. 2019) and preliminary report from Apatin, published as abstract (Perić et al. 2005), this East-Asian adventive species was almost unknown in Serbia. Our herbarium data and field observations suggest that it is wellestablished species in lowland riparian forests at few previously unknown or, at least, officially unpublished localities along the rivers Danube, Bosut and Sava. Its oldest herbarium record dates back to 1996. when this species was collected at Obedska Bara. Majority of our records originates from localities along the Danube river in the vicinity of Bezdan and Apatin, where this species creates densely populated stands in poplar-willow forests understory, especially at places not directly affected by floods with dense wild boar and deer populations. Species distribution in Serbia is presented in Fig. 34.

Its additional known records are in nearby transboundary areas of Croatia (Panjković 1990) and Hungary (Kovács \& Deme 2008) from where it was probably firstly introduced in Serbia (its sticky and tiny fruits are easily transported by floodwater and wild animals moving across the river). According to criteria of Niketić \& Tomović (2018) its invasive status in Serbia is considered to be: A(A) (initial phase of naturalization).

First records for Vojvodina province:

Bačka, Kolut, Sirota, along the channel Sirota, MGRS 34T UTM CR38, R. Perić 16-Nov-2010 (pers. comm.). 
Bačka, Apatin, city center, beside the wall, MGRS 34T UTM CR45, coll. et det. R. Perić 28-Aug-2004 (s.n. BUNS).

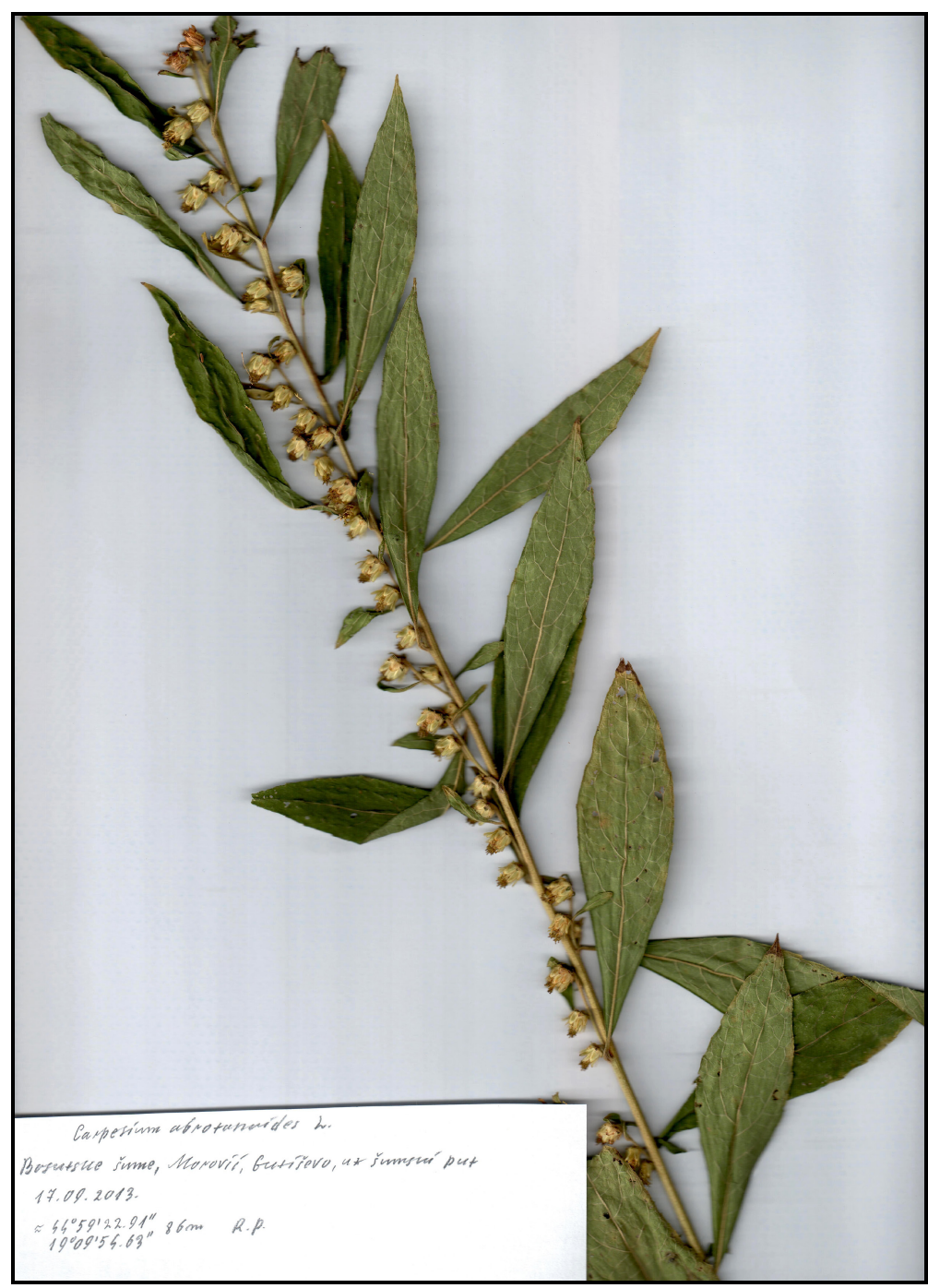

Fig. 27. - Carpesium abrotanoides L. (Srem, Bosut forests, s.n. PZZP).

Bačka, Apatin, Bestrement, forest edge, 79 m, 18.9471 E, 45.56927 N, MGRS 34T UTM CR34, coll. et det. R. Perić 05-Oct-2012 (s.n. PZZP).

Bačka, Apatin, Duboki Jendek, Veliki revir, MGRS 34T UTM CR34, R. Perić 26-Feb-2011 (pers. comm.).

Srem, Bosut forests, Gutiševo Bara, near a forest road, $86 \mathrm{~m}, \approx$ 19.16518 E, 44.9897 N, MGRS 34T UTM CQ58, coll. et det. R. Perić 17-Sep-2013 (s.n. PZZP) (Fig. 27). 
Srem, Obedska Bara, MGRS 34T DQ25, coll. V. Stojšić, det. R. Perić 11-Aug-2003 (s.n. PZZP).

Srem, Obedska Bara, Čenjin, at the mouth of Revenica river into the river Sava, MGRS 34T DQ14, coll. V. Stojšić, det. R. Perić 29-Aug1996 (s.n. PZZP).

A new allochthonous species for the flora of Vojvodina province.

R. Perić

Centaurea markiana J. Wagner, Magyar Bot. Lapok 2: 284 (1903), pro hybr.

= Centaurea magocsyana J. Wagner, Magyar Bot. Lapok 2: 281 (1903), pro hybr.

This centaury of hybrid origin belongs to the group of transitional taxa between $C$. jacea and $C$. phrygia groups which also includes $C$. macroptilon Borbás, C. oxylepis Hayek, etc. It was discovered and described from Mt Vršačke Planine in Vojvodina (Banat) (Wagner 1903) as a hybrid, $C$. ×markiana J. Wagner (C. [jacea subsp.] banatica $\times$ stenolepis). In the same paper author also described another hybrid, $C$. $\times$ magocsyana J. Wagner $(C$. [jacea subsp.] banatica $\times$ indurata $)$. The same author later synonymized $C$. × magocsyana with $C$. × markiana within the same combination, C. [jacea subsp.] banatica $\times$ stenolepis (Wagner 1939, 1943). According to him there is a whole palette of transitional forms in terms of phyllaries shape, where the 'markiana type' is more reminiscent of C. jacea subsp. banatica, while 'magocsyana type' has elongated phyllaries with pectinate-fimbriate appendages, more similar to C. stenolepis A. Kern. (from C. phrygia group). In the Flora Europaea Dostál (1976) neglected the name $C$. markiana and treated $C$. magocsyana as a separate microspecies, similar to C. macroptilon. In the case of inclusion of $C$. markiana in C. magocsyana, the plant have to be named C. markiana, because Wagner (1939) established the priority of the chosen name as first to unite them (Art. 11.5). Further research will show whether this fusion is appropriate or not. Plant with ' $C$. magocsyana type' have been mostly observed in Vojvodina, while some forms of 'markiana type' have been found in NE Serbia for the first time (Fig. 16). These specimens are similar to $C$. jacea but differ in tomentose leaves and phyllary appendages with \pm short pectinate-fimbriate acumens.

First records for Serbia proper:

NE Serbia, Miroč, from Veliki Štrbac to Miroč village, MGRS 34T EQ92, FQ03, coll. N. Diklić, M. Pajović 26-Jul-1955, det. N. Diklić (sub C. jacea), rev. M. Niketić 01-Apr-2020 (BEO 100010) (Fig. 28).

NE Serbia, Đerdap Gorge, Donji Milanovac, another stream towards Greben, Carpinus orientalis underbrush, 80-100 m, MGRS 34T EQ92, 
142 Niketić, M. et al.: ANNOTAted Checklist of VAscular Flora OF SERBIA II

coll. V. Nikolić, N. Diklić, M. Rakin 13-Sep-1965, det. N. Diklić (sub C. jacea subsp. banatica), rev. M. Niketić 01-Apr-2020 (BEO 100011).

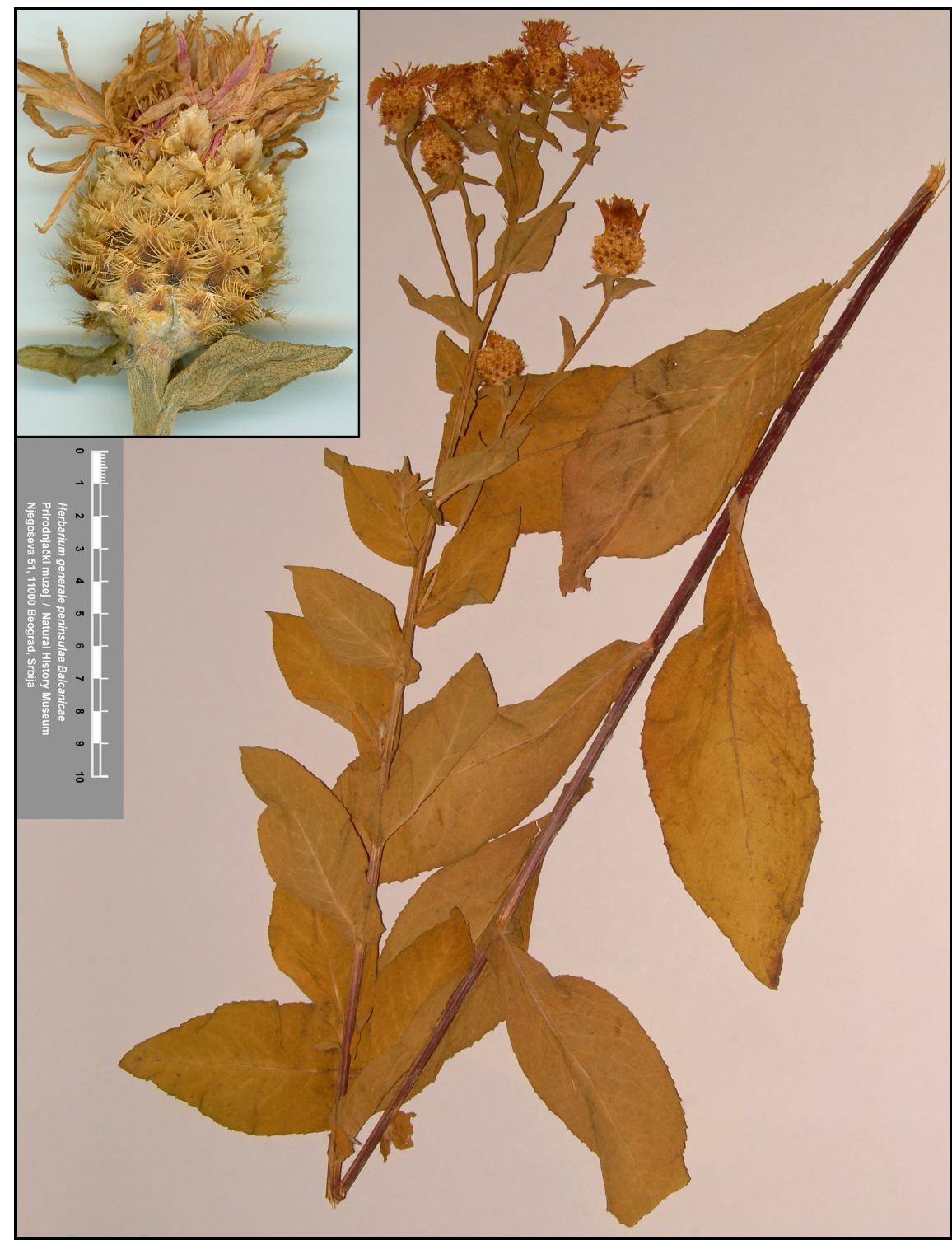

Fig. 28. - Centaurea markiana J. Wagner (NE Serbia, Đerdap Gorge, Donji Milanovac, BEO 100010).

NE Serbia, Đerdap Gorge, Donji Milanovac, between Kazanski and Varoški stream, beach forest, 80 m, MGRS 34T EQ82, coll. V. Nikolić, N. Diklić, M. Rakin 11-Sep-1965, det. N. Diklić (sub C. jacea subsp. banatica), rev. M. Niketić 01-Apr-2020 (BEO 100012). 
NE Serbia, Đerdap Gorge, Golubac, Golubac fortress, slopes towards the Danube, MGRS 34T EQ54, coll. V. Nikolić, N. Diklić 19-Sep1967, det. V. Nikolić (sub C. jacea subsp. banatica), rev. M. Niketić 01-Apr-2020 (BEO 100013).

A new species for the flora of Serbia proper.

M. Niketić

Erechtites hieraciifolius (L.) Raf. ex DC., Prodr. 6: 294 (1838).

This species originating from temperate North \& South America (Tutin 1976) has been precisely recorded in Serbia for the first and last time in the

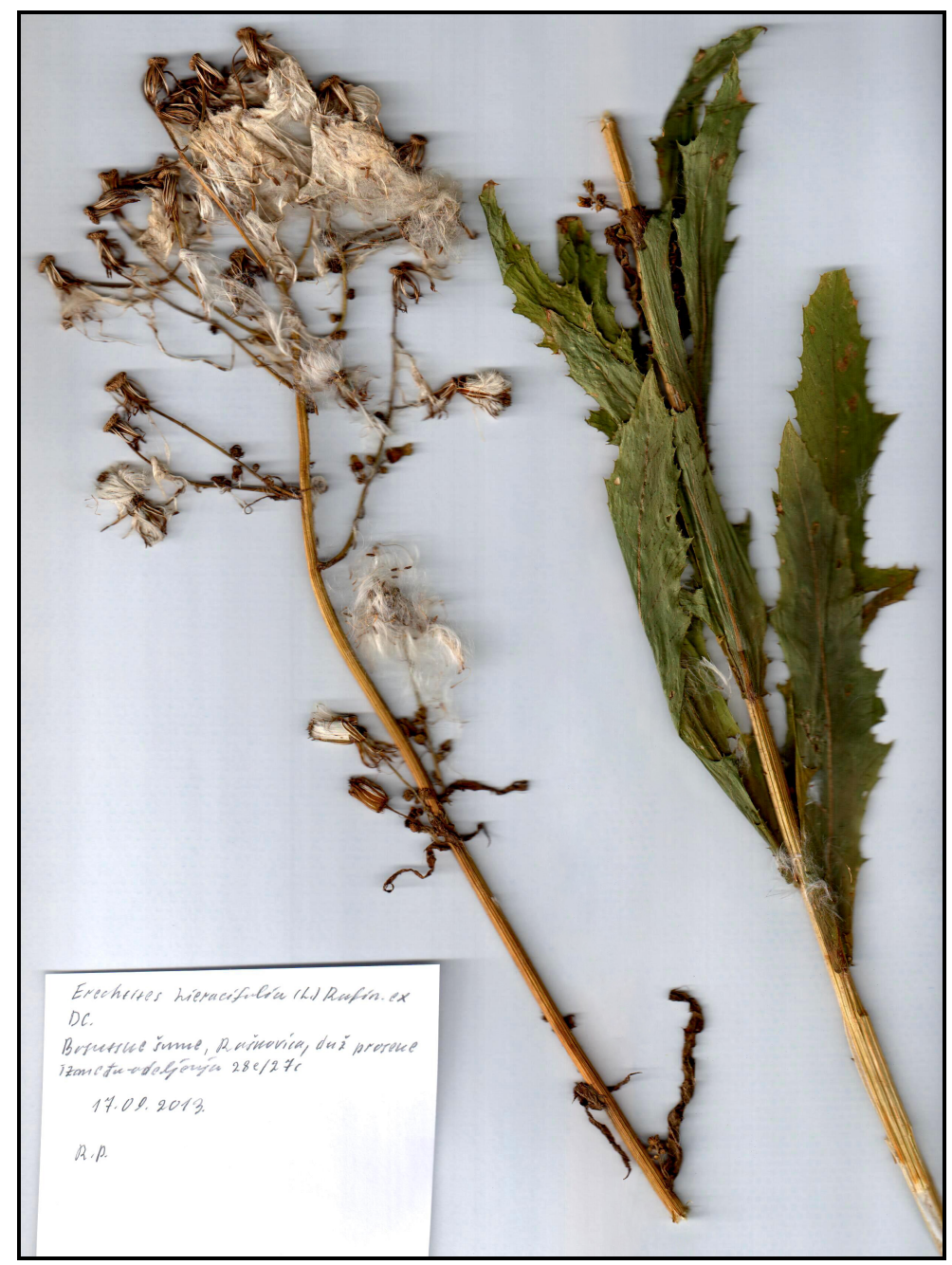

Fig. 29. - Erechtites hieraciifolius (L.) Raf. ex DC. (Srem, Bosut forests, Raškovica, s.n. PZZP). 
Đerdap Gorge (Iron Gate area near Tekija: Kovilovski stream) more than 50 year ago (Nikolić \& Diklić 1968). Its later citation for Vojvodina province (Obradović \& Panjković-Matanović 1986), despite remark that it is "domesticated" species here, has been published without any precise description of its exact habitats nor substantiated with herbarium specimens. Our field and herbarium data indicate that this species should still be considered rare casual with only two confirmed records in Serbia (Vojvodina province - Bosut forests and in the vicinity of Bezdan) (Fig. 16). Its typical habitats in Serbia are ruderal communities in wetland forests: along a forest paths and at open habitats disturbed by wild boars. Its closest next record is in the broad vicinity of Zagreb in Croatia (Nikolić 2020). Its invasive status in Serbia according to criteria of Niketić \& Tomović (2018) is: A(A) (initial phase of naturalization).

First records for Vojvodina province:

Srem, Bosut forests, Raškovica, from Manješevo Bara to Široka Bara, between forest compartments 28e/28c, along a forest path, MGRS 34T UTM CQ58, coll. et det. R. Perić 17-Sep-2013 (s.n. PZZP) (Fig. 29).

Bačka, Bezdan-Bački Monoštor, Štrbac, Crna Bara pond, western edge, MGRS 34T UTM CR47, R. Perić 22-Oct-2013 (pers. comm.).

Banat, Radojevo, field road to the Hetin village, the old airport for agricultural aviation, MGRS 34T UTM DR86, G. Anačkov 29-Sep2020 (pers. comm.).

Confirmed and for the first time located species for the flora of Vojvodina province.

R. Perić, G. Anačkov

Erigeron sumatrensis Retz., Observ. Bot. 5: 28 (1788).

Erigeron sumatrensis is native to South America, from where it has expanded to warm and temperate regions of the world, except to Antarctica (Vladimirov 2009 and literature therein). Concerning neighboring countries it has naturalized status in Slovenia, Croatia, Greece and Bulgaria and unknown status in Albania, Montenegro and European Turkey, while in Romania it is treated as an archeophyte (Greuter 2006+).

This adventive species was first reported for the territory of Serbia in the form of an abstract by Niketić \& Jovanović (2002) for the urban area of Belgrade. Later on, it was also confirmed for several localities in Serbia proper: E Serbia - surroundings of Niš, Leskovac and Gadžin Han by Zlatković \& Bogosavljević (2014) and NE Serbia - surroundings of Kladovo and Knjaževac and Šumadija - Ripanj near Belgrade by Bogosavljević \& Zlatković (2018). 


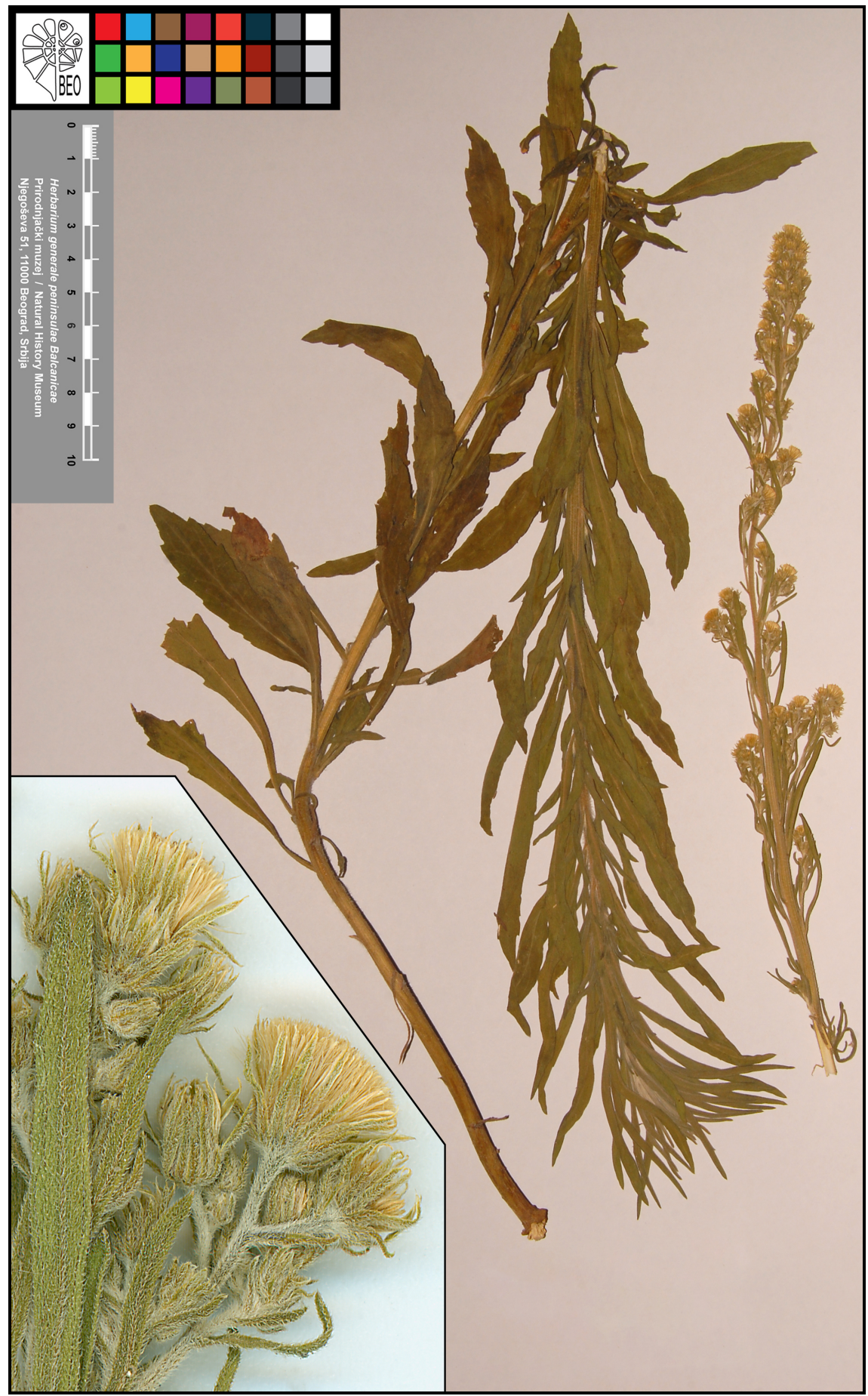

Fig. 30. - Erigeron sumatrensis Retz (Metohija, Prizren, BEO 100029). 
Erigeron sumatrensis grows in sunny warm habitats, usually ruderal one such as: along railroad tracks, abandoned arable land, road embankments and field margins, but it was also recorded in secondary grasslands, in near proximity to railways and roads (Vladimirov 2009). The results of our intensive field research in the area of Serbia Proper have confirmed its great invasive potential, so E. sumatrensis recently been observed on clearings within the forests of the lower belt in many locations.

This plant was included in the lists of invasive species of Serbia and Vojvodina province respectively (Vrbničanin et al. 2004, Stojanović \& Jovanović 2018, Rat et al. 2016). According to criteria of Niketić \& Tomović (2018) its invasive status in Serbia is: A(N) Naturalised (to a greater extent domesticated). A very large and dense population was also recorded for the first time for Kosovo and Metohija along the river Prizrenska Bistrica.

First record for Kosovo and Metohija province:

Metohija, Prizren, Prizrenska Bistrica river, alluvium, ruderal sites near the river bank, $400 \mathrm{~m}$, MGRS 34T DM77, coll. M. Niketić, G. Tomović, Š. Duraki 19-Jul-2007, det. M. Niketić (BEO 100029) (Fig. 30).

A new species for the flora of Kosovo and Metohija province.

M. Niketić, G. Tomović, Š. Duraki

Carlina acaulis subsp. caulescens (Lam.) Schübl. \& G. Martens, Fl. Würtemberg: 523 (1834).

三 Carlina caulescens Lam., Fl. Franç. $2: 7$ (1779) [basionym].

The species is listed for all neighboring countries of Serbia (Greuter 2006+) as well as for Kosovo and Metohija province (Košanin 1939, Meusel \& Kästner 1994). For the flora of Serbia proper it was preliminary anounced in Niketić (2000) for Mt Suva Planina in E Serbia.

First record for Serbia proper:

E Serbia, Mt Suva Planina, between Golemi Vrh and Rakoš peaks, limestone, rocky grounds and high-mountain pastures, $1500 \mathrm{~m}$, MGRS 34T FN07, coll. M. Niketić 14-Aug-1988, det. M. Niketić (BEO 100014) (Figs 31, 34).

A new subspecies for the flora of Serbia proper. 


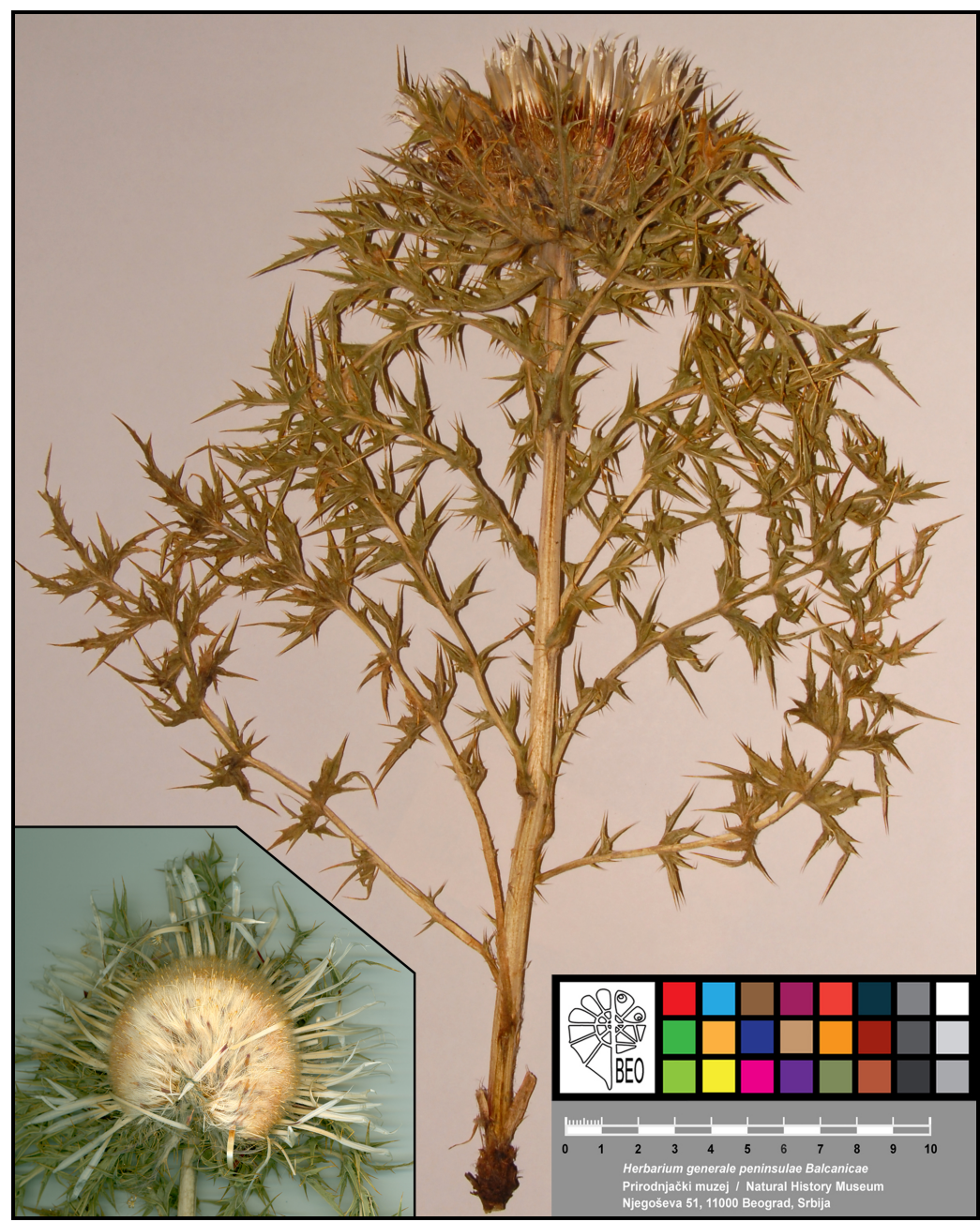

Fig. 31. - Carlina acaulis subsp. caulescens (Lam.) Schübl. \& G. Martens (E Serbia, Mt Suva Planina, BEO 100014).

M. Niketić

\section{CACTACEAE}

Opuntia humifusa (Raf.) Raf., Med. Fl. 2: 247 (1830).

$\equiv$ Cactus humifusus Raf., Ann. Nat. 1: 15 (1820) [basionym].

The natural range of this species of cactus includes arid areas of the temperate and subtropical zones of North America (POWO). It was introduced in a number of European countries where it is naturalized, especially in the Mediterranean. However, it is almost the only species of cactus that grows in the conditions of temperate-continental climate, which 
is characterized by cold winters. In the surrounding countries in Croatia, Romania and Bulgaria, it has status of naturalized species and grows in similar habitats as in Serbia (Korotkova \& Raab-Straube 2017).

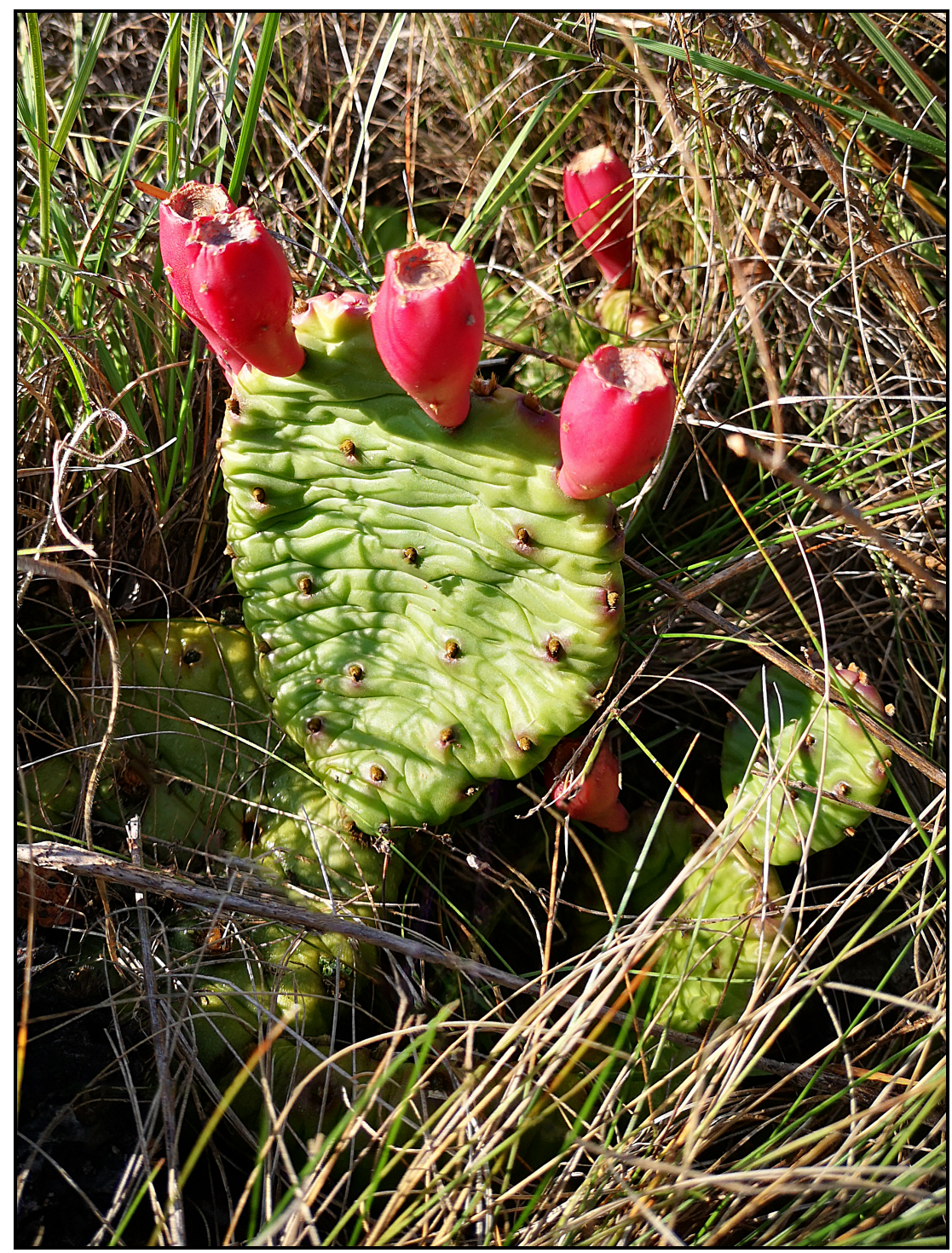

Fig. 32. - Opuntia humifusa (Raf.) Raf. (Banat, Deliblatska Sands, Mramorak) (photo M. Niketić).

The first (unpublished) record of this species in Serbia comes from NE Serbia (Korbovska Sands near Kladovo), where it was found in 1998 (coll. V. Stevanović, M. Niketić, G. Tomović, BEOU 12417). Ten years later, it was observed that this small population had expanded and was showing 
vitality. The origin of this population is unknown but it can be assumed that the species was introduced at Korbovska Sands from neighboring Romania. Opuntia humifusa was also recorded from SE Serbia in the valley of the river Pčinja near the village of Jablanica in dry sandy and rocky places on $475 \mathrm{~m}$ a.s.l. (coll. B. Zlatković, S. Bogosavljević, 09-Jul-2016, 13837 HMN!) (Bogosavljević \& Zlatković 2018, the first published record for Serbia) (Fig. 34).

The first locality where this species of cactus was found in Vojvodina is Deliblatska Sands: Mramorak vineyards where it was observed a few years ago by V. Stevanović. During the field investigation in October 2020, $O$. humifusa was found in several micro-localities in the wider area of Mramorak vineyards c. about $6 \mathrm{~km}$ away from the center of the village Mramorak. The origin of this population can be related to the German inhabitants, who were the majority in the village of Mramorak before World War II and who had its vineyards on the edge of the Deliblatska Sands. It is assumed that $O$. humifusa was transferred from Germany where it was grown on the sands of the Baltic seashore. As the vineyards were abandoned O. humifusa spread in this part of the Deliblatska Sands in the sandy vegetation as well as in the more open Robinia pseudoacacia forests.

First record for Vojvodina province:

Banat, Deliblatska Sands, Mramorak, Mramorak vineyards, forest and steppe vegetation, sand, $160 \mathrm{~m}$, MGRS 34T EQ07, $44.92519 \mathrm{~N}$, 21.0069 E, coll. M. Niketić, V. Stevanović, G. Tomović 27-Oct-2020, det. M. Niketić, V. Stevanović (BEO 100026) (Figs 32, 34).

\section{Additional record for the flora of Serbia proper:}

NE Serbia, Korbovo, Vajuga, sand, MGRS 34T FQ33, V. Stevanović, M. Niketić, G. Tomović 15-Jun-1998, det. M. Niketić, V. Stevanović (12417 BEOU).

A new allochthonous species for the flora of Vojvodina province.

V. Stevanović, M. Niketić, G. Tomović

\section{Erroneously reported taxa for the flora of Serbia}

\section{MAGNOLIOPSIDA}

ASTERACEAE (COMPOSITAE)

Amphoricarpos neumayerianus (Vis.) Greuter, Willdenowia 33: 51 (2003) subsp. neumayerianus

$\equiv$ Jurinea neumayeriana Vis., Fl. Dalmat.: t. 10, f. 2 (1842) [basionym].

In the Flora of SR Serbia (Gajić 1975), as well as in older literature sources, the presence of the species Amphoricarpos neumayerianus 
["Amphoricarpus neumayeri"] in Prokletije Mts was reported without specifying its infraspecific classification. Since the type subspecies occurs outside of Serbia (see on page 90), it should be considered that this data actually refers to A. neumayerianus subsp. autariatus (Blečić \& Mayer) Niketić.

\section{Niketić}

Carlina graeca Heldr. \& Sartori ex Boiss., Exsicc. (Herb. Graec. Norm.) 1855: n. 423 (1855).

Carlina graeca is an E Mediterranean plant recorded in Albania, Greece and Anatolia (Greuter 2006+). Although Zlatković \& Bogosavljević (2014) did not mention $C$. graeca as a new species for the flora of Serbia, they used this name accidentally, considering that it also includes Submediterranean $C$. corymbosa $\mathrm{L}$. as a synonym. Their citation of older records (Ilić 1902 ["Ničić"], Zlatković 2006) undoubtedly refers to C. corymbosa. The herbarium voucher (BEOU 16835) of their new finding (Mt Rujan Planina) also corresponds to this species.

\section{Specimen examined:}

Carlina corymbosa - S Serbia, Mt Rujan Planina, Slavujevac village, silicate, dry pastures, $800 \mathrm{~m}$, Festuco-Brometea, MGRS 34T EM68, coll. B. Zlatković, N. Smiljković 31-Jul-2008 (sub C. graeca), rev. B. Zlatković 15-Sep-2020 (BEOU 16835).

B. Zlatković, M. Niketić

Centaurea phrygia subsp. moesiaca (Urum. \& J. Wagner) Hayek, Repert. Spec. Nov. Regni Veg. Beih. 30(2): 789 (1931).

三 Centaurea moesiaca Urum. \& J. Wagner, Magyar Bot. Lapok 6: 165 (1907) [basionym].

The first literature data on taxon C. phrygia subsp. moesiaca (Urum. \& J. Wagner) Hayek in Serbia come from Kušan (1936): "Suva planina (Petrović), Vlasina (Pančić), Zlot kod Provalija u istočnoj Srbiji (Pelivanović)". These records have not been confirmed by field research so far. The same author also mentioned its presence in the flora of E Bosnia, but his descriptions of plants from certain localities (tomentose leaves and phyllary appendages with arcuate recurved, pectinate-fimbriate acumens) did not fit the description of taxon in the protologue and they are more in line with the characteristics of C. stenolepis A. Kern. Inspection of the original Pančić's material (identified by F. Kušan) from Vlasina plateau in SE Serbia (BEOU 10518) confirmed this suspicion and specimen has been revised as $C$. stenolepis. The same specimen was previously cited in Ranđelović \& Zlatković (2010), under the name "C. moesiaca". Conside- 
ring the great complexity of the $C$. phrygia group, the presence of this taxon in E Serbia could still be expected. For now, the presence of the species (C. phrygia) and subspecies (moesiaca) should be denied.

\section{Specimen examined:}

Centaurea stenolepis - SE Serbia, Vlasina plateau, coll. J. Pančić, det. F. Kušan 7-Mar-1934 (sub C. phrygia subsp. moesiaca), rev. M. Niketić 15-Feb-2020 (BEOU 10518).

M. Niketić

\section{CARYOPHYLLACEAE}

Arenaria biflora L., Mant. P1. 1: 71 (1767).

Despite different treatments on the taxonomic status and distribution of A. biflora L. and A. rotundifolia M. Bieb., the original opinion of McNeill (1963) that they are sister allopatric species has recently been resolved (Marhold 2011, POWO 2020). Arenaria biflora is an Alpine-Pyrenean species which presence in Bulgaria (Rila Mts) and Romania (Carpathians) should be checked. Arenaria rotundifolia is a Central Asiatic-Oriental-East Mediterranean orophyte which has inflorescences with several flowers and relatively narrower and \pm acute petals (vs. 1-2 flowers and obtuse petals in A. biflora). According to McNeill (1963), in the central part of the Balkan Peninsula grows subsp. pancicii (Degen \& Bald.) McNeill, with obovate (not orbicular) leaves, which "closely resembles the Central and East European A. biflora". In the Flora of Serbia (Diklić \& Stevanović 2012) and checklist of Albania (Barina et al. 2018) A. rotundifolia is synonymized with $A$. biflora. In Greek checklist (Dimopoulos et al. 2016) $A$. rotundifolia replace $A$. biflora. The study of the collected material showed that all specimens from Serbia, Montenegro and Albania belong to A. rotundifolia. This consequently excludes the presence of $A$. biflora in the flora of Serbia, although there are numerous literature data for it.

M. Niketić

\section{EUPHORBIACEAE}

Euphorbia agraria M. Bieb., Fl. Taur.-Caucas. 1: 375 (1808).

This Pontic plant is reported for the western part of its range to the flora of Romania, Bulgaria, Greece, Macedonia and Serbia (Hayek 1924). In the Flora of SR Serbia (Janković \& Nikolić 1972) only the presence of the variety E. agraria var. subhastata (Vis. \& Pančić) Hayek was mentioned, while for the type variety it was noted that it does not grow in Serbia. Lazarević et al. (2013) and Niketić (2014) restored the status of the species for the Balkan endemic E. subhastata Vis. \& Pančić which is primarily E Dinaric plant, but also was reported from Bulgaria, Dobruja and North 
152 Niketić, M. ET AL.: ANNOTATEd CHECKLIST OF VASCUlar FlORA OF SERBIA II

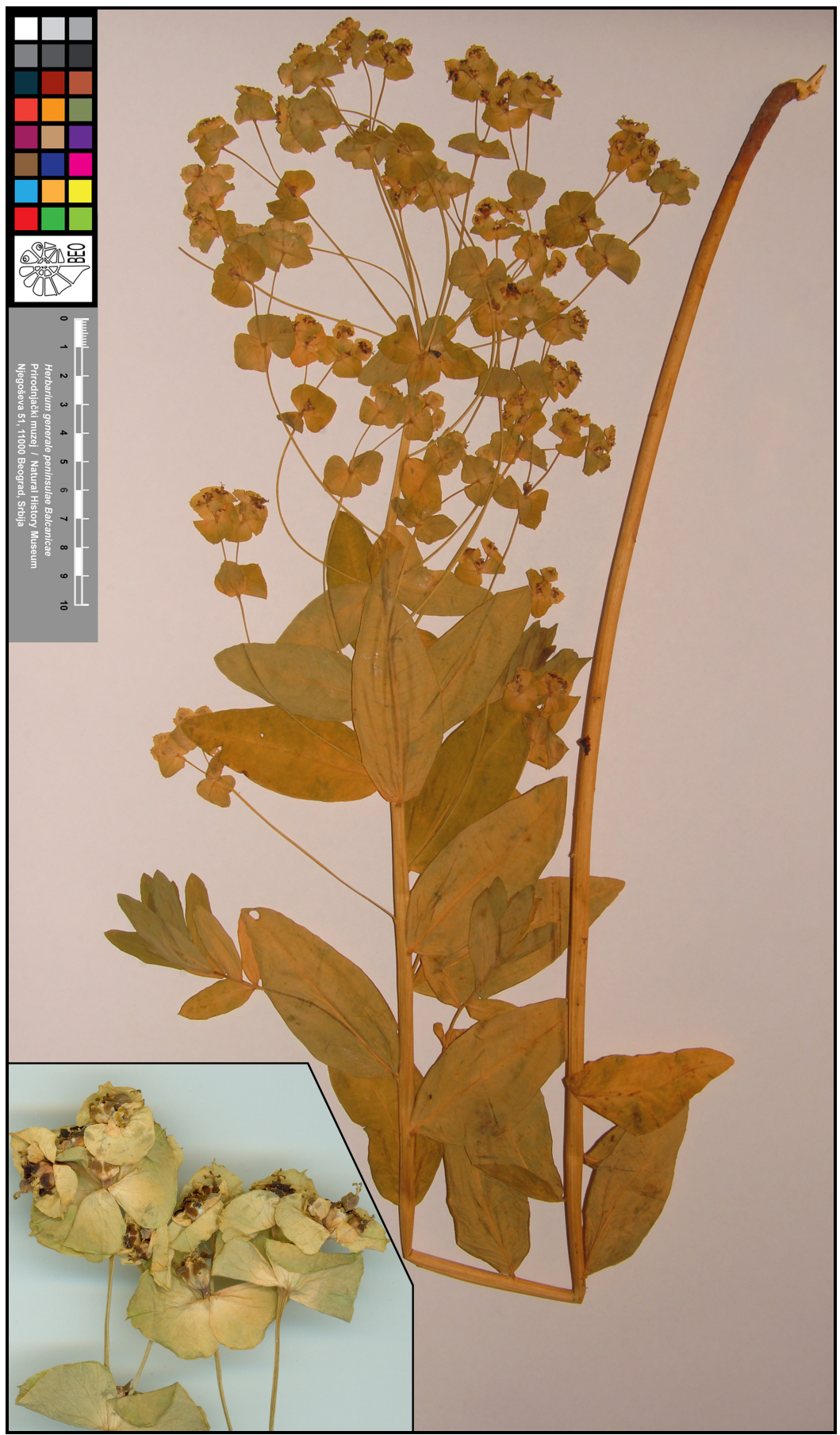

Fig. 33. - Euphorbia lucida f. latifolia (W. D. J. Koch) Prodan (E Serbia, Niš, Duvanište, Nišava river bank, BEO 100030). 


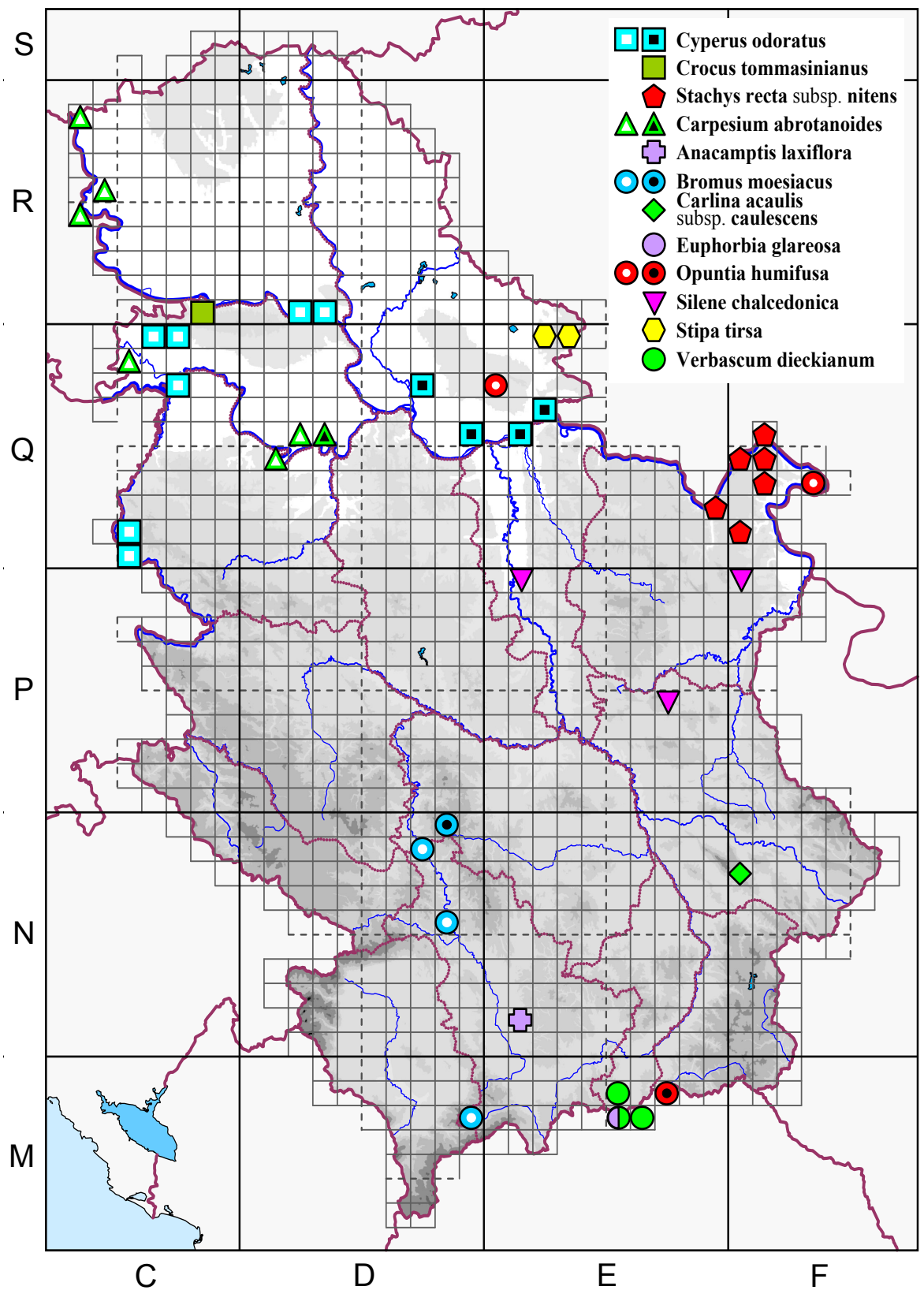

Fig. 34. - Distribution of some new taxa for the vascular flora of Serbia or administrative units. Only the new or confirmed localities in Vojvodina are mapped for Crocus tommasinianus and Stipa tirsa as well as a new locality in Kosovo and Metohija for Anacamptis laxiflora. Small squares, triangles and circles within symbols: white - new record; black - literature record. 
Macedonia (Hayek 1924). However, it remained questionable whether Pontic E. agraria M. Bieb. really grows in Serbia, and its presence has not been confirmed yet. Some sources about its presence probably refer to $E$. subhastata (treated within E. agraria) (Krasnići 1972) or maybe to some other species (Sigunov 1965), e.g. E. esula L. On the other hand, field verification (2005, BEO 100030) of the previous record for E. agraria var. subhastata from vicinity of Niš (Niketić 1985) showed that the population of this plant actually contains extremely broadleaved morphotype of Euphorbia lucida [f. latifolia (W. D. J. Koch) Prodan]. Since this morphotype is dominant in many populations of lowland areas of Serbia, its relations with the common Pontic-C European Euphorbia lucida Waldst. \& Kit. should be clarified in the future.

Specimen examined:

Euphorbia lucida f. latifolia - E Serbia, Niš, Duvanište, Nišava river bank, MGRS 34T EN79, coll. M. Niketić, G. Tomović 05-Jun-2005, det. M. Niketić, G. Tomović (BEO 100030, 23831 BEOU) (Fig. 33).

M. Niketić, G. Tomović

\section{Erroneously reported taxa for the flora of administrative units}

\section{MAGNOLIOPSIDA}

\section{ASTERACEAE (COMPOSITAE)}

Scorzonera parviflora Jacq., Fl. Austriac. 4: 3 (1776). [Serbia proper]

Ranđelović et al. (2008) listed this taxon for the flora of Lalinac saltmarsh area, located in the vicinity of Niš. In fact, the basis for this record refers to poorly developed specimens of $T$. pratensis subsp. orientalis (L.) Čelak. A revision of herbarium material, as well as a detailed observation of salt marsh habitats in a given area in the recent period, confirmed the absence of $S$. parviflora from Serbia proper.

B. Zlatković

\section{BRASSICACEAE (CRUCIFERAE)}

Erysimum crepidifolium Rchb., Icon. Fl. Germ. Helv. 1: 8 (1834). [Serbia proper]

The distribution of this C European species in Serbia has been usually confused with the distribution of $E$. diffusum group. It has been partially corrected in the Atlas Florae Europae (Jalas \& Suominen 1994) in which authors expressed doubt about the presence of the species in Serbia. According to Niketić (1999) "only two specimens, collected in Serbia and kept in old herbarium material, are true E. crepidifolium". The first one was collected by J. Pančić in the region of Srem in Vojvodina (BEOU). The other one was collected from the modern urban area of Belgrade (Dedinje, 
Košutnjak), where natural habitats under trees are still preserved (BEO). Since the collected material was in the juvenile stage, its identification was not certain. Recent field exploration has shown that E. odoratum Ehrh. actually grows in this locality, which has similar dentation and hairiness of the lower leaves in the juvenile stage as E. crepidifolium. Therefore, the presence of E. crepidifolium in the area of Serbia proper should be denied. However, aforementioned Pančić's specimen from Vojvodina (BEOU) still corresponds to this species, which is considered extinct from the flora of Serbia.

\section{Specimen examined:}

Erysimum odoratum - Šumadija, Beograd, Dedinje, Careva česma, MGRS 34T DQ55, coll. O. Grebenščikov 03-Apr-1945, det. O. Grebenščikov (sub E. crepidifolium), rev. M. Niketić 28-Feb-2020 (s.n. BEO).

M. Niketić

\section{CAPRIFOLIACEAE (DIPSACACEAE)}

Knautia magnifica Boiss. \& Orph., Bull. Congr. Bot. Petersb. 1869: 138 (1870). [Kosovo and Metohija]

= Knautia midzorensis Formánek, Deutsche Bot. Monatsschr. 16: 19 (1898).

In Diklic (1973) and other sources there are several data on the presence of " $K$. midzorensis" in the territory of Kosovo and Metohija. According to Niketić (2014) and POWO (2020) this name has to be included in very variable $K$. magnifica Boiss. \& Orph. As mentioned on page 99 its presence in administrative unit Kosovo and Metohija is unlikely and all records of $K$. magnifica (incl. K. midzorensis) should be treated as erroneous and attributed to K. csikii Jáv. \& Szabo.

M. Niketić

\section{Acknowledgements}

The authors would like to thank Dr. Nicholas Turland from the Botanischer Garten und Botanisches Museum Berlin, Germany who helped us to overcome certain nomenclature concerns for Stachys nitens. Dr. Jindrich Chrtek jun. from the National Museum in Prague, Czech Republic and Dr Bogdan Iuliu Hurdu from the Institute of Biological Research, National Institute for Research and Development in Biological Sciences, Cluj-Napoca, Romania offered us the literature sources for Stachys nitens. We are thankful to Dr Božo Frajman from the University of Innsbruck, Austria for providing chorological observation for the representatives of Euphorbia nicaeensis complex. Special thanks to Dr Svetlana Bancheva for sending and allowing the inspection of original specimens of Centaurea phrygia subsp. moesiaca from the Bulgarian Academy of Sciences, Sofia, Bulgaria (SOM). 


\section{REFERENCES}

Amidžić, L., Panjković, B., Perić, R. (2013): Chorological analysis of the endemic flora in the Metohian Prokletije mountains. - Archives of Biological Sciences 5(2): 645-650.

Anačkov, G., Niketić, M., Tomović, G. (2018): Liliopsida: Liliaceae s.l. (Amaryllidaceae-Xanthorrhoeaceae). In: Niketić, M., Tomović, G. (2018): An annotated Checklist of Vascular Flora of Serbia 1. Lycopodiopsida, Polypodiopsida, Gnetopsida, Pinopsida and Liliopsida [Catalogue of taxa]: 91-102. Serbian Academy of Sciences and Arts, Belgrade.

APG IV (2016): An update of the Angiosperm Phylogeny Group classification for the orders and families of flowering plants: APG IV. - Botanical Journal of the Linnean Society 181: 1-20.

Ball, P. W. (1993): Hesperis L. In: Tutin, T. G., Burges, N. A., Chater, A. O., Edmondson, J. R., Heywood, V. H., Moore, D. M., Valentine, D. H., Walters, S. M., Webb, D. A. (eds): Flora Europaea, ed. 2, 1: 336-337. - University Press, Cambridge.

Barina, Z., Pifko, D., Mesterhazy, A. (2011): Contributions to the flora of Albania, 3. - Willdenowia 41(2): 329-339.

Barina, Z., Somogyi, G., Pifkó, D, Rakaj, M. (2018): Checklist of vascular plants of Albania. - Phytotaxa 378(1): 1-339.

Bartha, D., Király, G. (2015): Distribution atlas of vascular plants of Hungary (Atlas Florae Hungariae). - University of West Hungary, Faculty of Forestry, Institute of Botany and Nature Conservation, Sopron.

Beck, G. (1920): Flora Bosne, Hercegovine i bivšeg Sandžaka Novog Pazara 2(9). - Glasnik Zemaljskog Muzeja Bosne i Hercegovine 32: 83-127. [in SerboCroatian]

Behr, O, Behr, E, Zahn, K. H. (1937): Beitrag zur Kenntnis der Hieracien der Balkanhalbinsel. - Glasnik Skopskog Naučnog Društva 18, Sect. Sci. Nat. 6: 51-67.

Behr, O, Behr, E, Zahn, K. H. (1939a): Beiträge zur Kenntnis der Hieracien von Südserbien. - Glasnik Skopskog Naučnog Društva 20, Sect. Sci. Nat. 7: 23-34.

Behr, O, Behr, E, Zahn, K. H. (1939b): Beiträge zur Kenntnis der Hieracien von Südserbien, Montenegro und Griecheland. - Glasnik Skopskog Naučnog Društva 20, Sect. Sci. Nat. 7: 121-129.

Beldie, A. (1979): Flora României: determinator ilustrat al plantelor vasculare 2. Academiei R.S.R., București.

Blečić, V. (1953): Prilog poznavanju flore severne Crne Gore. - Glasnik Prirodnjačkog muzeja Srpske zemlje 5-6: 21-28. [in Serbian]

Blečić, V., Mayer, E. (1967): Die europäischen Sippen der Gattung Amphoricarpos Visiani. - Phyton 12: 150-158.

Bogosavljević, S., Zlatković, B. (2018): Report on the new floristic data from Serbia II. - Biologica Nyssana 9(2): 63-75.

Bošnjak, K. (1936): Iz hercegovačke flore. - Glasnik Hrvatskog Prirodoslovnoga Društva 41-48: 62-63. 
Buttler, K. P. (1991): Hieracium L. In: Strid, A., Tan. K. (eds): Mountain flora of Greece 2: 595-642. - University Press, Edinburgh.

Caković, D., Stešević, D., Schönswetter, P., Frajman, B. (2015): How many taxa? Spatiotemporal evolution and taxonomy of Amphoricarpos (Asteraceae, Carduoideae) on the Balkan Peninsula. - Organisms Diversity and Evolution 15: 429-445.

Chater, O. A. (1972): Brunnera Steven. In: Tutin, T. G., Heywood, V. H., Burges, N. A., Moore, D. M., Valentine, D. H., Walters, S. M., Webb, D. A. (eds.): Flora Europaea 3: 106. - University Press, Cambridge.

Chrtek, J. jun. (1992): Taxonomical Remarks on the Stachys recta Group. - Folia Geobotanica and Phytotaxonomica 27(2): 177-183.

De Sanctis, M., Fanelli, G., Gjeta, E., Mullaj, A., Attorre, F. (2018): The forest communities of Shebenik-Jabllanicë National Park (Central Albania). Phytocoenologia 48(1): 51-76.

Degen, A. (1905): Bemerkungen über einige orientalische Pflanzenarten. - Magyar Botanikai Lapok 4(4-5): 82-83.

Dénes, A. (2000): A Villányi-hegység flóra- és vegetációkutatásának története, eredményeinek összefoglalása, különös tekintettel a védett és ritka fajok előfordulására. - Dunántúli Dolgozatok Természettudományi Sorozat 10: 4777. [in Hungarian with English summary]

Diklić, N. (1972): Alyssum L. In: Josifović, M. (ed.): Flora SR Srbije 3: 286-311. Srpska akademija nauka i umetnosti, Beograd [in Serbian].

Diklić, N. (1973): Dipsacaceae B. Juss. In: Josifović, M. (ed.): Flora SR Srbije 5: 536-607 [615]. - Srpska akademija nauka i umetnosti, Beograd [in Serbian].

Diklić, N. (1974): Stachys L. [In: Diklić, N., Janković, M. M.: Lamiaceae Lindley]. In: Josifović, M. (ed.): Flora SR Srbije 6: 408-432. - Srpska akademija nauka i umetnosti, Beograd [in Serbian].

Diklić, N. (1976): Orchidaceae Lindl. In: Josifović, M. (ed.): Flora SR Srbije 8: 36-116. - Srpska akademija nauka i umetnosti, Beograd. [in Serbian]

Diklić, N., Stevanović, V. (2012): Arenaria L. In: Stevanović, V. (ed.): Flora Srbije, ed. 2, 2: 251-256. - Srpska akademija nauka i umetnosti, Beograd. [in Serbian]

Dimitrov, D. S., Vutov, V. M. (2015): Poa stiriaca Dörfl. In: Greuter, W., RaabStraube, E. (eds): Euro+Med-Checklist Notulae, 5: 461. - Willdenowia 45(3): 449-464.

Dimopoulos, P., Raus, T., Bergmeier, E., Constantinidis, T., Iatrou, G., Kokkini, S., Strid, A., Tzanoudakis, D. (2016): Vascular plants of Greece: An annotated checklist. Supplement. - Willdenowia 46(2): 301-347.

Djordjević, V., Niketić, M., Tomović, G. (2018): Liliopsida: Orchidaceae. In: Niketić, M., Tomović, G. (2018): An Annotated Checklist of Vascular Flora of Serbia 1. Lycopodiopsida, Polypodiopsida, Gnetopsida, Pinopsida and Liliopsida [Catalogue of taxa]: 102-110 - Serbian Academy of Sciences and Arts, Monographs 690, Department of Chemical and Biological Sciences 10, Belgrade. 
Domina, G. (2017): Dipsacaceae. In: Euro+Med Plantbase - the information resource for Euro-Mediterranean plant diversity. [http://ww2.bgbm.org/Euro PlusMed/] (retrieved May $\left.1^{\text {st }} 2020\right)$.

Dostál, J. (1976): Centaurea L. In: Tutin, T. G., Heywood, V. H., Burges, N. A., Moore, D. M., Valentine, D. H., Walters, S. M., Webb, D. A. (eds): Flora Europaea 4: 254-301. - University Press, Cambridge.

Duraki, Š., Niketić, M. (2018a): Hieracium djimilense subsp. brachytrichophyes O. Behr \& al. In: Raab-Straube, E., Raus, T. (eds): Euro+Med-Check Notulae, 9: 201. - Willdenowia 48(2): 195-220.

Duraki, Š., Niketić, M. (2018b): Hieracium oroglaucum O. Behr \& al. subsp. oroglaucum. In: Raab-Straube, E., Raus, T. (eds): Euro+Med-Check Notulae, 9: 201-202. - Willdenowia 48(2): 195-220.

Duraki, Š., Niketić, M. (2018c): Hieracium bohatschianum subsp. platytrigonodon O. Behr \& al. In: Raab-Straube, E., Raus, T. (eds): Euro+Med-Check Notulae, 9: 200. - Willdenowia 48(2): 195-220.

Duraki, Š., Niketić, M. (2018d): Hieracium sparsum subsp. squarrosobracchiatum O. Behr \& al. In: Raab-Straube, E., Raus, T. (eds): Euro+Med-Check Notulae, 9: 202-203. - Willdenowia 48(2): 195-220.

Edmondson, J. R. (1980): Poa L. In: Tutin, T. G., Heywood, V. H., Burges, N. A., Moore, D. M., Valentine, D. H., Walters, S. M., Webb, D. A. (eds): Flora Europaea 5: 159-167. - Cambridge University Press, Cambridge, New York, Melbourne.

Eggler, J. (1955): Ein Beitrag zur Serpentinvegetation inder Gulsen bei Kraubath in Obersteiermark. - Mitteilungen des Naturwissenschaftlichen Vereines für Steiermark 85: 27-72.

Ferakova, V., Mered'a, P., Hodálová, I., Eliáš, P., Petrović, D., Stevanović, V. (2011): Dianthus nitidus. In: The IUCN Red List of Threatened Species 2011: e.T161959A5519631.

Frajman, B, Rešetnik, I., Niketić, M., Ehrendorfer, F., Schönswetter, P. (2016): Patterns of rapid diversification in heteroploid Knautia sect. Trichera (Caprifoliaceae, Dipsacoideae), one of the most intricate taxa of the European flora. - BMC Evolutionary Biology 16(204): 1-20

Formánek, E. (1896): Zweiter Beitrag zur Flora von Serbien, Macedonien und Thessalien. - Verhandlungen des Naturforschenden Vereins in Brünn 34: 255365 .

Fukarek, P. (1965): Rasprostranjenost i ekološke karakteristike krčagovine Amphoricarpus neumayeri Vis. - Glasnik Zemaljskog muzeja u Sarajevu, Prirodne nauke 3-4: 159-180.

Gajić, M. (1975): Asteraceae Dumortier. In: Josifović, M. (ed.): Flora SR Srbije 7: 1-465. - Srpska akademija nauka i umetnosti, Beograd. [in Serbian]

Galasso, G., Conti, F. Peruzzi, F. Ardenghi, N. M. G., Banfi, E., Celesti-Grapow, L., Albano, A. Alessandrini, A., Bacchetta, G., Ballelli, S., Bandini Mazzanti, M., Barberis, G., Bernardo, L., Blasi, C., Bouvet, D. Bovio, M., Cecchi, L., Del Guacchio, E., Domina, G., Fascetti, S., Gallo, L., Gubellini, L. Guiggi, A., Iamonico, D., Iberite, M., Jiménez-Mejías, P. Lattanzi, E., Marchetti, D., Martinetto, E., Masin, R. R., Medagli, P., Passalacqua, N. G., Peccenini, S., 
Pennesi, R., Pierini, B., Podda, L. Poldini, L., Prosser, F., Raimondo, F. M., Roma-Marzio, F., Rosati, L., Santangelo, A., Scoppola, A., Scortegagna, S., Selvaggi, A., Selvi, A., Soldano, A., Stinca, A., Wagensommer, R. P., Wilhalm, T., Bartolucci, F. (2018): An updated checklist of the vascular flora alien to Italy. - Plant Biosystems 152(2): 179-303.

Gavrilović, B., Tomović, G., Niketić, M., Milenković, M., Simić, S., Radovanović, M. (2017): Geoecological characteristics of plant endemism in the Balkan part of Serbia. - Botanica Serbica 41(2): 177-197.

Gavrilović, M. M. (2019): Taxonomy and phylogeny of the Xeranthemum group (Asteraceae) - morphological, anatomical, phytochemical and molecular aspects. - University of Belgrade, Faculty of Biology, Belgrade. (PhD Thesis, manuscr.) [in Serbian with English Abstract]

Geltman, D. V. (2015): Podrod Esula roda Euphorbia (Euphorbiaceae): sistema, filogenija, geografičeskij analiz. - Federal'noe gosudarstvennoe bjudžetnoe učreždenie nauki Botaničeskij institut im. V.L. Komarova Rossijskoj akademii nauk. (PhD Thesis, manuscr.) [in Russian]

Geltman, D. V. (2020): A synopsis of Euphorbia (Euphobiaceae) for the Caucasus. - Novitates Systematicae Plantarum Vascularium 51: 43-78.

Govaerts, R. (2020): World Checklist of Liliaceae. - Royal Botanic Gardens, Kew. [http://wcsp.science.kew.org] (retrieved September $1^{\text {st }} 2020$ )

Govaerts, R., Fernández Casas, F. J., Barker, C., Carter, S., Davies, S., Esser, H-J., Gilbert, M., Hoffmann, P., Radcliffe-Smith, A., Steinmann, V., Welzen, P., Whitmoore, T. (2020): World Checklist of Euphorbiaceae. - Royal Botanic Gardens, Kew. [http://wcsp.science.kew.org] (retrieved October $\left.1^{\text {st }} 2020\right)$

Greuter, W. (2003): The Euro Med treatment of Cardueae (Compositae) - generic concepts and required new names. - Willdenowia 33(1): 49-61.

Greuter, W. (2006+): Compositae (pro parte majore). In: Greuter, W. \& Raab-Straube, E. von (eds): Compositae. Euro+Med Plantbase - the information resource for Euro-Mediterranean plant diversity. [http://ww2.bgbm.org/EuroPlusMed/ PTaxonDetail.asp?NameId=14103\&PTRefFk=7000000] (retrieved September $1^{\text {st }}$ 2020)

Grisebach, A, Schenk, A. (1852): Iter hungaricum a. 1852 susceptum. Beiträge zur Systematik der ungarischen Flora. - Archiv für Naturgeschichte 18(1): 291-362.

Hand, R. (2011): Apiaceae. In: Euro+Med Plantbase - the information resource for Euro-Mediterranean plant diversity. [http://ww2.bgbm.org/EuroPlusMed/] (retrieved June 1st 2020).

Hansen, A. (1976): Rudbeckia L. In: Tutin, T. G., Heywood, V. H., Burges, N. A., Moore, D. M., Valentine, D. H., Walters, S. M., Webb, D. A. (eds): Flora Europaea 4: 141. - Cambridge University Press, Cambridge, New York, Melbourne.

Hayek, A. (1924): Prodromus florae peninsulae balcanicae 1(1). - Repertorium specierum novarum regni vegetabilis, Beihefte 30(1): 1-160.

Hayek, A. (1929): Prodromus florae peninsulae balcanicae 2(3). - Repertorium specierum novarum regni vegetabilis, Beihefte 30(2): 241-336.

Horvatić, S. (1928): Oblici sekcije Leucanthemum iz roda Chrysanthemum u flori Jugoslavije. - Acta Botanica Instituti Botanici Universitatis Zagrebiensis. 
Izvešća Botaničkog Zavoda kr. Sveučilišta u Zagrebu 3: 61-140. [in Croatian with German Summary]

Hundozi, B. (1981): Përsëri mbi disa lloje bimore të florës së Kosovës (Again about some plant species of flora of Kosovo). - Zbornik radova PMF Priština Ser. A, Biologija-Hemija 8: 127-131 [in Albanian with Serbian summary].

Ilić, Đ. I. (1902): Još nekoliko biljka iz Vranjske okoline koje nisu navedene u građi za floru u okolini Vranja. Izveštaj - gimnazija Nemanjina u Vranju. Štamparija D. Dimitrijevića. Beograd. [in Serbian]

Ilnicki, T., Szeląg, Z. (2011): Chromosome Numbers in Hieracium and Pilosella (Asteraceae) From Central and Southeastern Europe. - Acta Biologica Cracoviensia, Series Botanica 53(1): 102-110.

Jafari, F., Zarre, S., Gholipour, A., Eggens, F., Rabeler, R. K., Oxelman, B. (2020): A new taxonomic backbone for the infrageneric classification of the speciesrich genus Silene (Caryophyllaceae). - Taxon 69(2): 337-368.

Jalas, J., Suominen, J. (eds) (1994): Atlas Florae Europaeae 10. Cruciferae (Sisymbrium to Aubrietia). - Committee for Mapping the Flora of Europe, Helsinki, Societas Biologica Fennica, Vanamo.

Janka, V. (1860): Adnotationes in plantas dacicas nonnullasque alias europaeas. Linnaea 30: 549-622.

Janka, V. (1868): Correspondenz. - Österreichische botanische Zeitschrift 18(2): 57.

Janković, I., Šatović, Z., Liber, Z., Kuzmanović, N., Di Pietro, R., Radosavljević, I., Nikolov, Z., Lakušić, D. (2019): Genetic and morphological data reveal new insights into the taxonomy of Campanula versicolor s.l. (Campanulaceae). Taxon 68(2): 340-369.

Janković, M. M., Nikolić, V. (1972): Euphorbiaceae J. St.-Hill. In: Josifović, M. (ed.): Flora SR Srbije 3: 537-570. - Srpska akademija nauka i umetnosti, Beograd [in Serbian].

Jarić, S., Karadžić, B., Mataruga, Z., Kostić, O., Mitrović, M., Pavlović, P. (2019): Alohtone biljne vrste u flori i vegetaciji Crnog luga (jugozapadni Srem). Acta herbologica 28(1): 31-58. [in Serbian]

Jávorka, S. (1964): Hazai Crocus-aink. - Botanikai Közlemenyek 51(2): 177-182. [in Hungarian with German summary]

Jovanović, S., Hlavati-Širka, V., Lakušić, D., Jogan, N., Nikolić, T., Anastasiu, P., Vladimirov, V., Šinžar-Sekulić, J. (2018): Reynoutria taxa niche modelling and protected areas prioritization for restoration and protection from invasion: Southeastern Europe case study. - Journal for Nature Conservation 41: 1-15.

Kevey, B. (1990 [1989]): Adatok Magyarország flórájának és vegetációjának ismeretéhez V. - Botanikai Közlemenyek 76(1-2): 83-96. [in Hungarian with German summary]

Király, G., Baraniai-Nagy, A., Kerekes, S., Király, A., Korda, M. (2009): Kiegészítések a magyar advenív-flóra ismeretéhez IV. - Flora Pannonica 7: 331. [in Hungarian with English abstract]

Kojić, C. S. (2002): Biogeografija Gornje Morave. - NIJP Kosovsko Pomoravlje, Gnjilane [in Serbian]. 
Korotkova, N. \& Raab-Straube, E. (2017): Cactaceae. In: Euro+Med Plantbase the information resource for Euro-Mediterranean plant diversity. [http://ww2. bgbm.org/EuroPlusMed/] (retrieved September $1^{\text {st }}$ 2020)

Košanin, N. (1939): Über die Vegetation von Nordalbanien. - Srpska kraljevska akademija, Spomenik 89, Prvi razred 20: 73-107.

Kovács, Gy., Deme, T. (2008): Idős tölgyesek az Alsó-Duna árterén. - Somogyi Múzeumok Kózleményei 18: 43-50. [in Hungarian]

Kožuharov, S., Petrova, A., Ehrendorfer, F. (1981): Evolutionary patterns in some brome grass species (Bromus, Gramincae) of the Balkan Peninsula. Botanische Jahrbücher für Systematik, Pflanzengeschichte und Pflanzengeographie 102: 381-391.

Krasnići, F. (1972): Šumska vegetacija brdskog regiona Kosova. - Zajednica naučnih ustanova Kosova. Studije 27, Priština. [in Serbian Latin].

Kušan, F. (1936): Oblici sekcije Eujacea i Lepteranthus u flori Jugoslavije. Prirodoslovna istraživanja Kraljevine Jugoslavije 20: 1-79. [in Croatian]

Lakušić, D. (1996): Survey of the flora of Mt. Kopaonik (S. W. Serbia, Yugoslavia). - Ekologija 31(2): 1-35.

Lakušić, D., Niketić, M., Tomović, G. (2018): Liliopsida: Poaceae (Gramineae). In: Niketić, M., Tomović, G. (2018): An Annotated Checklist of Vascular Flora of Serbia 1. Lycopodiopsida, Polypodiopsida, Gnetopsida, Pinopsida and Liliopsida [Catalogue of taxa]: 110-138 - Serbian Academy of Sciences and Arts, Monographs 690, Department of Chemical and Biological Sciences 10, Belgrade.

Lakušić, R. (1966): Vegetacija livada i pašnjaka na planini Bjelasici. - Godišnjak Biološkog instituta Univerziteta u Sarajevu 19: 1-186.

Lampinen R. (2001): Universal Transverse Mercator (UTM) and Military Grid Reference System (MGRS). [http://www.luomus.fi/english/botany/ afe/map/ utm.htm]

Lazarević, P., Krivošej, Z., Tomović, G., Stevanović, V. (2013): Euphorbia subhastata Vis. \& Pančić. In: Vladimirov, V., Dane, F., Stevanović, V., Tan. K. (eds): New floristic records in the Balkans, 22: 282. - Phytologia Balcanica 19(2): 279-283.

Lazarević, P., Zlatković, B. (2018): Ranunculus aconitifolius L. (Ranunculaceae), a taxon new for the flora of Serbia. - Botanica Serbica 42(1): 147-151.

Leute, G. H. (1978): Ergebnisse einer botanischen Sammelreise durch das sudliche Jugoslawien im Jahre 1969. - Annalen des Naturhistorischen Museums in Wien 81: 75-105.

Lozina-Lozinskaya, A. S. (1970): Rumex L. In: Komarov, V. L. (ed.): Flora of the U.S.S.R. 5: 445-501. - Akademii Nauk, Moskva-Leningrad.

Maly, K. (1909): ? Euphorbia variabilis Ces. - Magyar Botanikai Lapok 8(1-4): 93.

Maly, K. (1934): Beiträge zur Kenntnis der Picea omorika. - Glasnik Zemaljskog muzeja u Bosni i Hercegovini 46: 37-64.

Marhold, K. (2011+): Verbascum. In: Euro+Med Plantbase - the information resource for Euro-Mediterranean plant diversity [http://ww2.bgbm.org/Euro PlusMed/] (retrieved May $\left.1^{\text {st }} 2020\right)$. 
Marhold, K. (2011): Caryophyllaceae. In: Euro+Med PlantBase - the information resource for Euro-Mediterranean plant diversity [http://ww2.bgbm.org/Euro PlusMed/] (retrieved May $\left.1^{\text {st }} 2020\right)$.

Maslo, S., Šarić, Š., Sarajlić, N. (2020): Sison amomum L. (Apiaceae), a new species in the flora of Bosnia and Herzegovina. - Glasnik Hrvatskog botaničkog društva $8(1)$ : 15-18.

Mataruga, Z., Jarić, S., Karadžić, B., Mitrović, M., Kostić, O., Marković, M., Pavlović, P. (2016): Prilog poznavanju alohtone flore u donjem toku reke Save. - Acta herbologica 25(1): 57-70. [in Serbian]

Matveeva, J. (1968): Floristička karakteristika na Osoj. - Fragmenta Balcanica 6: 141-148 [in Macedonian].

Maw, G. (1881): A synopsis of the genus Crocus. - The Gardeners' Chronicle 16: $367-368$.

Maw, G. (1886): A monograph of the genus Crocus. - Dulau et co., London.

McNeill, J. (1963): Taxonomic studies in the Alsinoideae: II. A revision of the species in the Orient. - Notes From The Royal Botanic Garden Edinburgh 24: 241-404.

Meusel, H., Jäger, E. (1992): Vergleichende Chorologie der zentraleuropäischen Flora 3. Text. - Gustav Fischer, Jena, Stuttgart, New York.

Meusel, H., Kästner, A. (1994): Lebensgeschichte der Gold- und Silberdisteln Monographie der mediterran-mitteleuropäischen Compositen-Gattung Carlina 2. - Springer, Wien.

Meyer, F. K. (2011): Beiträge zur Flora von Albanien. - Haussknechtia, suppl. 15: $1-220$.

Niketić, M. (1985): Prilog flori okoline Niša. In: Ranđelović, N. (ed.): Simpozijum Stogodišnjica flore okoline Niša, Zbornik radova: 45-49. - Niš [in Serbian Latin].

Niketić, M. (1999): Erysimum crepidifolium Reichenb. In: Stevanović, V. (ed.): The Red Data Book of Flora of Serbia 1. Extinct and critically endangered taxa: 115-116, 434-435. - Ministry of Environment of the Republic of Serbia, Faculty of Biology, University of Belgrade, Institution for protection of nature of the Republic of Serbia, Belgrade. [in Serbian with English Summary]

Niketić, M. (2000): Novi taksoni za floru cvetnica Srbije i susednih područja. In: 6. Simpozijum o flori jugoistočne Srbije i susednih područja sa međunarodnim učešćem: 32-33. - Sokobanja (Abstract) [in Serbian Latin]

Niketić, M. (2005): Novi podaci o rasprostranjenju nekih ređih biljaka u Srbiji. In: Randjelović, N. (ed.): 8. Simpozijum o flori jugoistočne Srbije i susednih područja sa međunarodnim učešćem: 47. - Prirodno-matematički fakultet, Niš. (Abstract) [in Serbian Latin]

Niketić, M. (2010): Novi taksoni za floru cvetnica Srbije i susednih područja 2. In: 10. Simpozijum o flori jugoistočne Srbije i susednih regiona: 32-33. - Niš (Abstract) [in Serbian Latin]

Niketić, M. (2014): Nomenclature review of the plants published by Josif Pančić (Nomenclator Pancicianus novus). - Botanica Serbica 38(2): 209-236. 
Niketić, M., Jovanović, S. (2002): Conyza sumatrensis nova adventivna vrsta u flori Srbije. In: 7. Simpozijum o flori jugoistočne Srbije i susednih područja sa međunarodnim učešćem: 23. - Dimitrovgrad (Abstract) [in Serbian Latin].

Niketić, M., Tomović, G. (2018): An Annotated Checklist of Vascular Flora of Serbia 1. Lycopodiopsida, Polypodiopsida, Gnetopsida, Pinopsida and Liliopsida - Serbian Academy of Sciences and Arts, Monographs 690, Department of Chemical and Biological Sciences 10, Belgrade.

Niketić, M., Tomović, G., Perić, R., Zlatković, B., Anačkov, G., Djordjević, V., Jogan, N., Radak, B., Duraki, Š., Stanković, M., Kuzmanović, N., Lakušić, D., Stevanović, V. (2018a): Material on the Annotated Checklist of Vascular Flora of Serbia. Nomenclatural, taxonomic and floristic notes I. - Bulletin of the Natural History Museum in Belgrade 11: 101-180.

Niketić, M., Tomović, G., Anačkov, G., Djordjević, V., Lakušić, D., Randjelović, V., Jogan, N. (2018b): Komentari / Comments. In: Niketić, M., Tomović, G.: An annotated Checklist of Vascular Flora of Serbia 1. Lycopodiopsida, Polypodiopsida, Gnetopsida, Pinopsida and Liliopsida: 175-208. - Serbian Academy of Sciences and Arts, Monographs 690, Department of Chemical and Biological Sciences 10, Belgrade.

Nikolić, T. (2020): Flora Croatica Database. - Faculty of Science, University of Zagreb, Zagreb. [http://hirc.botanic.hr/fcd/] (accessed: October $\left.1^{\text {st }} 2020\right)$.

Nikolić, V., Diklić, N. (1968): O nekim retkim i novim vrstama biljaka za floru Jugoslavije i Srbije sa područja Đerdapske klisure. - Glasnik Prirodnjačkog muzeja u Beogradu, serija B, 23: 39-58. [in Serbian]

Nikolić, V., Sigunov, A., Diklić, N. (1986): Dopuna Flori SR Srbije novim podacima o rasprostranjenju biljnih vrsta. In: Sarić, M., Diklić, N. (eds): Flora SR Srbije 10: 259-351. - Srpska akademija nauka i umetnosti, Beograd [in Serbian].

Novaković, J., Zlatković, B., Lazarević, M., Garcia-Jacas, N., Susanna, A., Marin, P. D., Lakušić, D., Janaćković, P. (2018): Centaurea zlatiborensis (Asteraceae, Cardueae-Centaureinae), a new endemic species from Zlatibor mountain range, Serbia. - Nordic Journal of Botany 36(6): e01893, 1-8.

Obradović, M., Panjković-Matanović, V. (1986): Adventivna flora Vojvodine. Matica Srpska, zbornik za prirodne nauke 70: 99-114. [in Serbian]

Pahlevani, A. H. (2017): Diversity of the genus Euphorbia (Euphorbiaceae) in SW Asia. - Fakultät Biologie Chemie Geowissenschaften der Universität Bayreuth. (PhD Thesis, manuscr.).

Pančić, J. (1856): Verzeichniss der in Serbien wildwachsenden Phanerogamen, nebst den Diagnosen einiger neuer Arten. - Verhandlungen des Zoologischbotanischen Vereins in Wien 6: 475-598.

Pančić, J. (1867): Botanische Ergebnisse einer i. J. 1866 unternommenen Reise in Serbien. - Österreichische botanische Zeitschrift 17(6): 166173.

Pančić, J. (1874): Flora Kneževine Srbije. - Državna štamparija, Beograd. [in Serbian]

Pančić, J. (1884): Dodatak Flori Kneževine Srbije. - Kraljevsko-srpska državna štamparija, Beograd. [in Serbian] 
Panjković, B. (1990): Analiza životnih oblika i flornih elemenata u flori Baranje (Hrvatske). - Acta Botanica Croatica 49: 107-123. [in Croatian]

Papeš, D. (1973): Leucanthemum illyricum (Horvatić) Papeš, comb. nov. et stat. nov. - Acta Botanica Croatica 32: 243-251. [in Croatian with English Summary]

Perić, R., Knežević, J., Rućando, M., Feješ, E., Nikolić, K., Beljin, V., Dačić, J. (2005): Prilog poznavanju flore Zapadne Bačke. In: Randjelović, N. (ed.): 8. Simpozijum o flori jugoistočne Srbije i susednih područja sa međunarodnim učešćem: 58. - Prirodno-matematički fakultet, Niš. (Abstract) [in Serbian Latin]

Perić, R., Rilak, S. (2017): Eclipta prostrata (L.) L. (Compositae), an adventive species new to the flora of Serbia. - Botanica Serbica 41(1): 89-93.

Petrović, S. (1882): Flora okoline Niša. - Kraljevsko-srpska državna štamparija, Beograd. [in Serbian]

Poljakov, P. P. (1961): Artemisia L. In: Schischkin, B. K., Bobrov, E. G. (eds): Flora USSR 26: 425-631. - Institutum botanicum nomine V. L. Komarovii Academiae scientarum URSS, Moskva ["Mocqua"], Leningrad. [in Russian]

POWO (2020): Plants of the world online. - The Royal Botanic Gardens, Kew. [http://www.plant softh eworl donli ne.org/]

Priszter, S. (1964a): Occurrence of Crocus tommasinianus Herb in Hungary. Acta Biologica Academiae Scientiarum Hungaricae 15: 49. [in Hungarian with German summary] (retrieved August $25^{\text {th }}$ 2020).

Priszter, S. (1964b): Új sáfrányfaj (Crocus tommasinianus Herb.) Magyarországon. - Botanikai Közlemenyek 51(2): 183-185.

Pulević, V. (1977): Prilog poznavanju taksonomije i horologije Crocus tommasinianus Herbert (Iridaceae). - Poljoprivreda i šumarstvo (Titograd) 223(1): 53-60.

Radak, B. Đ., Vlku, A. Z. Peškanov, J. M., Matevski, V. S., Anačkov, G. T. (2019): Morphological characterization of three natural hybrid orchid taxa, new for Serbia, Montenegro and North Macedonia. - Archives of Biological Sciences 71(4): 597-607.

Radulović, S. (2002a): Carpesium abrotanoides L., nova vrsta za floru Srbije u lovištu „Crni Lug“. - Glasnik Sumarskog fakulteta 86: 173-180 [in Serbian with English summary].

Radulović, S. (2002b): The basic site characteristics of the species Carpesium abrotanoides L. - Acta herbologica 11(1-2): 15-22.

Ranđelović, N., Stamenković, V. (1984): Flora i vegetacija Rujan planine u jugoistočnoj Jugoslaviji. - Leskovački zbornik 24: 375-392.

Ranđelović, N., Stamenković, V. (1985): Iščezle, ugrožene i retke biljke jugoistočne Srbije predložene za zaštitu. In: Randjelović, N. (ed.): Simpozijum „Stogodišnjica flore okoline Niša“. - Zbornik radova. Univerzitet u Nišu, Tehnološki fakultet u Leskovcu. Podružnica Srpskog biološkog društva Niš, 57-65. [in Serbian Latin]

Ranđelović, V., Zlatković, B. (2010): Flora i vegetacija Vlasinske visoravni. Prirodno-matematički fakultet, Niš. [in Serbian Latin] 
Ranđelović, V., Zlatković, B., Dimitrijević, D. (2008): Fitogeografska analiza flore Lalinačke slatine. In: $9^{\text {th }}$ Symposium on the flora of Southeastern Serbia and neighboring regions, Proceeding: 73-82. - University of Niš, Faculty of Sciences and Mathematics, Niš. [in Serbian with English abstract]

Randjelović, N., Hill, D. A., Randjelović, V. (1990): The genus Crocus L. in Serbia. - Serbian Academy of Sciences and Arts, Monographs 601, Department of Natural and Mathematical Sciences 66, Belgrade.

Rat, M., Simonović, P., Glavendekić, M., Paunović, M., Stojanović, V., Karaman, M., Radišić, D., Anačkov, G. (2016): Overview of the invasive alien species in Serbia. In: Rat, M., Trichkova, T., Scalera, R., Tomov, R., Uludag, A. (eds): ESENIAS Scientific Reports 1. State of the Art of Alien Species in SouthEastern Europe. [Country reports]. - University of Novi Sad, Novi Sad, Serbia, IBER-BAS, Bulgaria, ESENIAS, Novi Sad, 91-114.

Raus, Th., Strid, A. (2020): New combinations in some Balkan Centaurea taxa. Phytologia Balcanica 26(3): 505-507.

Răvăruț, M. (1960): Stachys L. In: Săvulescu, T., Nyárády, E. I. (eds): Flora Republicii Populare Romîne 8: 208-233. - Academia Republicii Populare Romîne, Bucureşti. [in Romanian]

Rohlena, J. (1913): Fünfter Beitrag zur Flora von Montenegro. - Sitzungsberichte der Königlichen Böhmischen Gesellschaft der Wissenschaften. Mathematischnaturwissenschaftliche Classe 1912: 1-143.

Rohlena, J. (1942): Conspectus Florae Montenegrinae. - Preslia 20-21: 1-506.

Sabovljević, M. S., Tomović, G., Niketić, M., Lazarević, P., Lazarević, M., Latinović, J., Latinović, N., Kabaš, E., Đurović, S. Z., Kutnar, L., Skudnik, M., Pantović, J., Stevanoski, I., Vukojićić, S., Veljić, M. (2020): New records and noteworthy data of plants, algae and fungi in SE Europe and adjacent regions, 1. - Botanica Serbica 44(1): 81-87.

Sell, P. D., West, C. (1976): Hieracium L. In: Tutin, T. G., Heywood, V. H., Burges, N. A., Moore, D. M., Valentine, D. H., Walters, S. M., Webb, D. A. (eds): Flora Europaea 4: 358-410. - Cambridge University Press, Cambridge, New York, Melbourne.

Sigunov, A. (1965): Prilog poznavanju flore i šumske vegetacije okoline Majdanpeka - Glasnik Muzeja šumarstva i lova 5: 55-102. [in Serbian Latin].

Skokanová, K., Hodálová, I., Mered’a Jr., P., Slovák, M., Kučera, J. (2019): The Cyanus tuberosus group (Asteraceae) in the Balkans: biological entities require correct names. - Plant Systematics and Evolution 305(8): 569-596.

Sl. glasnik RS (2010-2011): Pravilnik o proglašenju i zaštiti strogo zaštićenih i zaštićenih divljih vrsta biljaka, životinja i gljiva. - „Sl. glasnik RS“, br. 5/2010 i 47/2011. [in Serbian]

Smith A. R., Tutin, T. G. (1968): Euphorbia L. In: Tutin, T. G., Heywood, V. H., Burges, N. A., Moore, D. M., Valentine, D. H., Walters, S. M., Webb, D. A. (eds): Flora Europaea 2: 213-226. - University Press, Cambridge.

Stanković, M., Đorđević, S., Bartula, M., Đorđević-Milošević, S., Milošević, S., Pejić, D. (2018): New sites of allochthonous species Cyperus odoratus L. (fam. Cyperaceae) in the middle flow of the Drina river watershed. In: Anačkov, G., Zorić, L. (eds): $7^{\text {th }}$ Balkan Botanical Congress, Book of 
Abstracts. - University of Novi Sad, Faculty of Sciences, Department of Biology and Ecology, Novi Sad, Botanical Society "Andreas Wolny", Novi Sad. - Botanica Serbica 42 (Supplement 1): 121.

Stefanović, V. (1960): Tipovi šuma bijelog bora na području krečnjaka istočne Bosne. - Naučno društvo Bosne i Hercegovine, Radovi, XVI, Odjeljenje privredno-tehničkih nauka, knjiga 4, Sarajevo.

Stevanović, V., Šinžar-Sekulić, J., Stevanović, B. (2004): Expansion of the adventive species Paspalum paspaloides (Michx.) Schribner, Echinochloa oryzoides (Ard.) Fritsch and Cyperus strigosus L. in the Yugoslav part of the Danube reservoir ( $\mathrm{km} \mathrm{1090-1075).} \mathrm{-} \mathrm{The} \mathrm{Proceedings} \mathrm{of} \mathrm{the} \mathrm{International}$ Association for Danube Research 35: 399-405.

Stevanović, V., Tan, K., Tomašević, M., Uotila, P. (2005): The occurrence of Cyperus strigosus (Cyperaceae) in Serbia and Montenegro. - Phytologia Balcanica 11(2): 137-138.

Stojanović, V., Jovanović, I. (2018): Pregled invazivnih i potencijalno invazivnih vrsta biljaka u Republici Srbiji i okruženju u cilju utvrđivanja njihovog statusa na nacionalnom nivou. - Zaštita prirode 68(1-2): 41-59. [in Serbian with English summary]

Stojanović, V., Stevanović, V. (2008): Prikaz flore planine Gučevo u Severozapadnoj Srbiji. - Zaštita prirode 59(1-2): 93-108.

Suranyi, G., Máthé, C., Mosolygó, A. Borbély, G., Vasas, G. (2010): Analysis of genetic diversity in crocuses with Carpathian Basin origin using AFLPmarkers. - Acta Biologica Hungarica 61 (Suppl.): 149-155.

Süveges, K., Löki, V., Lovas-Kiss, Á., Ljubka, T., Fekete, R., Takács, A., Vincze, O., Molnár, V. A. (2019): From European priority species to characteristic apophyte: Epipactis tallosii (Orchidaceae). - Willdenowia 49(3): 401-409.

Svoboda, C. (2012): Grasses (Poaceae) from the Balkan Peninsula. - Studii şi cercetări, Biology 17: 19-45.

Szeląg, Z. (2015): Hieracia balcanica X. Typification of the Hieracium (Asteraceae) names described by K. H. Zahn from the Balkan Peninsula. - Polish Botanical Journal 60(1): 41-65.

Szeląg, Z., Vladimirov, V. (2013): A new species of Hieracium sect. Pannosa (Asteraceae) from Bulgaria. - Phytotaxa 108(1): 57-60.

Šajinović, B., Mihajlov, M. (1979): Jovan Tucakov and the Deliblato Sand. In: Čanak, M. (ed.): II Međunarodni simpozijum o zaštiti i unapređivanju Deliblatskog peska. - Društvo ekologa Vojvodine, Novi Sad. [in Serbian with English summary]

Španiel, S., Zozomová-Lihová, J., Marhold, K. (2017): Revised taxonomic treatment of the Alyssum montanum-A. repens.- Plant Systematics and Evolution 303(10): 1413-1442.

complex in the Balkans: a multivariate morphometric analysis

Tan, K. (1991): Amphoricarpos Vis. In: Strid, A., Tan, K. (eds): Mountain flora of Greece 2: 472-473. - University Press, Edinburgh. 
Thiers, B. (2021): Index Herbariorum: A global directory of public herbaria and associated staff. New York Botanical Garden's Virtual Herbarium. http:// sweetgum.nybg.org/ih (retrieved October 10 $0^{\text {th }} 2020$ )

Tomović, G., Niketić, M., Lakušić, D., Randjelović, V., Stevanović, V. (2014): Balkan endemic plants in Central Serbia and Kosovo regions: distribution patterns, ecological characteristics and centres of diversity. - Botanical Journal of the Linnean Society 176(2): 173-202

Tomović, G., Sabovljević, M. S., Djokić, I., Petrović, P., Djordjević, V., Lazarević, P., Mašić, E., Barudanović, S., Ștefănuţ, S., Niketić, M., Butorac, B., Pantović, J., Hajrudinović Bogunić, A., Bogunić, F., Kabaš, E., Vukojičić, S., Kuzmanović, N., Djurović, S. Z., Buzurović, U. (2020): New records and noteworthy data of plants, algae and fungi in SE Europe and adjacent regions, 2. Botanica Serbica 44(2): 251-259.

Turland, N. J., Wiersema, J. H., Barrie, F. R., Greuter, W., Hawksworth, D. L., Herendeen, P. S., Knapp, S., Kusber, W-H., Li, D-Z., Marhold, K., May, T. W., McNeill, J., Monro, A. M., Prado, J., Price, M. J., Smith, G. F. (2018): International Code of Nomenclature for algae, fungi, and plants (Shenzhen Code) adopted by the Nineteenth International Botanical Congress Shenzhen, China, July 2017. - Regnum Vegetabile 159.

Tutin, T. G. (1968): Sison L. In: Tutin, T. G., Heywood, V. H., Burges, N. A., Moore, D. M., Valentine, D. H., Walters, S. M., Webb, D. A. (eds.): Flora Europaea 2: 352. - University Press, Cambridge.

Tutin, T. G. (1976): Erechtites Rafin. In: Tutin, T. G., Heywood, V. H., Burges, N. A., Moore, D. M., Valentine, D. H., Walters, S. M., Webb, D. A. (eds): Flora Europaea 4: 191. - Cambridge University Press, Cambridge, New York, Melbourne.

Tzonev, R., Zieliński, J., Tan, K. (2003): Cyperus strigosus (Cyperaceae), a naturalized species new to Bulgaria. - Polish Botanical Journal 48(1): 47-49.

Valdés, B. (2011): Boraginaceae. In: Euro+Med Plantbase - the information resource for Euro-Mediterranean plant diversity. [http://ww2.bgbm.org/Euro PlusMed/] (retrieved May $1^{\text {st }} 2020$ ).

Verloove, F. (2014): A conspectus of Cyperus s.l. (Cyperaceae) in Europe (incl. Azores, Madeira and Canary Islands), with emphasis on non-native naturalized species. - Webbia 69(2): 179-223.

Vladimirov, V. (2009): Erigeron sumatrensis (Asteraceae): a recently recognized alien species in the Bulgarian flora. - Phytologia Balcanica 15(3): 361-365.

Vrbničanin, S., Karadžić, B., Dajić-Stevanović, Z. (2004): Adventivne i invazivne korovske vrste na području Srbije. - Acta herbologica 13(1): 1-12. [in Serbian with English summary]

Vučković, M. (1991): Livadska i livadsko-stepska vegetacija Vršačkih Planina. Matica Srpska, Odeljenje za prirodne nauke, Novi Sad. [in Serbian with English summary]

Vukićević, E. (1965): Sukcesija vegetacije i prirodno obnavljanje šuma na šumskim požarištima u Srbiji. Doktorska disertacija. - Glasnik Šumarskog fakulteta 29: $1-87$. 
Vukićević, E. (1976): Stipa L. In: Josifović, M. (ed.): Flora Srbije 8: 316-322. Srpska akademija nauka i umetnosti, Beograd. [in Serbian]

Vuksanović, S. (2016): Rasprostranjenje, horološka struktura i centri diverziteta balkanske endemične flore u Crnoj Gori. - University of Belgrade, Faculty of Biology, Belgrade. (PhD Thesis, manuscr.) [in Serbian with English Summary].

Wagner, J. (1903): Neue Centaurea- Bastarde. - Magyar Botanikai Lapok 2(9-10): 281-287.

Wagner, J. (1939): Bemerkungen über Centaureen. - Acta Universitatis Szegediensis, Section Science Naturalis, Pars Bot. 5(3-4): 73-113.

Wagner, J. (1943): Észrevételek Nyárády E. Gy.: Adatok a hazai Centaureák "Jacea" és "Phrygia" csoportjainak bővebb ismeretéhez, különös tekintettel Kolozsvár környékének flórájára. - Borbásia Nova 15: 1-23. [in Hungarian]

Webb, D. A. (1976). Amphoricarpos Vis. In: Tutin, T. G., Heywood, V. H., Burges, N. A., Moore, D. M., Valentine, D. H., Walters, S. M., Webb, D. A. (eds): Flora Europaea 4: 243. - University Press, Cambridge.

Wraber, T. (1982): De Euphorbia pancicii G. Beck notula. - Glasnik Republičkog zavoda za zaštitu prirode - Prirodnjačkog muzeja u Titogradu 15: 77-84.

Wraber, T. (1988): The discovery of Dianthus nitidus Waldst. \& Kit. in Montenegro (Yugoslavia). - Biološki vestnik 36(4): 95-102.

Zahn, K. H. (1921): Compositae (Hieracium). In: Engler, A. (ed.): Das Pflanzenreich: 289-576. - Regni Vegeabilis Conspectus 76 (IV.280), Wilhelm Engelmann, Leipzig.

Zahn, K. H. (1936): Hieracium L. In: Ascherson, P. F. A. \& Graebner, K. O. P. P. (eds): Synopsis der mitteleuropäischen Flora, 12(3): 1-320. - Gebrüder Borntraeger, Berlin.

Zahn, K. H. (1937): Hieracium L. In: Ascherson, P. F. A. \& Graebner, K. O. P. P. (eds): Synopsis der mitteleuropäischen Flora, 12(3): 321-480. - Gebrüder Borntraeger, Berlin.

Zahn, K. H. (1938): Hieracium L. In: Ascherson, P. F. A. \& Graebner, K. O. P. P. (eds): Synopsis der mitteleuropäischen Flora, 12(3): 481-708. - Gebrüder Borntraeger, Berlin.

Zlatković, B. (2006): Carlina corymbosa L. In: Greuter, W., Raab-Straube, E. (eds): Euro+Med Notulae, 2: 709. - Willdenowia 36 (2): 707-717.

Zlatković, B. K., Bogosavljević, S. S. (2020): Risk analysis of alien plants recorded in thermal waters of Serbia. - Weed Research 60(1): 85-95.

Zlatković, B., Bogosavljević, S. (2014): Report on the new floristic data from Serbia. - Biologica Nyssana 5(2): 123-129.

Zlatković, B., Randjelović, V., Randjelović, N. (1993): Građa za floru jugoistočne Srbije. In: Randjelović, N. (ed.): III Simpozijum o flori jugoistočne Srbije. Flora i vegetacija. Zbornik radova. - Univerzitet u Nišu, Tehnološki fakultet u Leskovcu. Leskovac-Pirot, 95-110. [in Serbian Latin]

ZZPS (2011): Stručna osnova za izradu zakona o Nacionalnom parku „Šarplanina“. Studija zaštite. - Zavod za zaštitu prirode Srbije, Beograd. [in Serbian] 


\title{
МАТЕРИЈАЛ ЗА КРИТИЧКУ ЛИСТУ ВРСТА ВАСКУЛАРНЕ ФЛОРЕ СРБИЈЕ. НОМЕНКЛАТУРНИ, ТАКСОНОМСКИ И ФЛОРИСТИЧКИ ПРИЛОЗИ II
}

\author{
Р Е 3 И М Е
}

МАРЈАН НИКЕТИЋ, ГОРДАНА ТОМОВИЋ, ГОРАН АНАЧКОВ, МИРЈАНА БАРТУЛА, СЛАЂАНА ЂОРЪЕВИЋ, ВЛАДАН ЂОРЪЕВИЋ, СУЗАНА ЂОРЂЕВИЋ-МИЛОШЕВИЋ, ШЕМИЈА ДУРАКИ, МИЛАН ГАВРИЛОВИЋ, ПЕЂА ЈАНАЋКОВИЋ, ЕВА КАБАШ, НЕВЕНА КУЗМАНОВИЋ, ДМИТАР

ЛАКУШИЋ, ПРЕДРАГ ЛАЗАРЕВИЋ, РАНКО ПЕРИЋ, ВЛАДИМИР

РАНЪЕЛОВИЋ, ДРАГИША САВИЋ, МИХАЈЛО СТАНКОВИЋ, ИВАНА

СТЕВАНОСКИ, ВЕРИЦА СТОЈАНОВИЋ, ОЛГА ВАСИЋ, СНЕЖАНА ВУКОЈИЧИЋ, БОЈАН ЗЛАТКОВИЋ, ВЛАДИМИР СТЕВАНОВИЋ

У раду је предложено девет нових номенклатурних комбинација и назначено је осам нових синонима. Поред тога, представљено је 12 таксона (врста и подврста) васкуларне флоре који су нови за флору Србије (од тога девет аутохтоних и три алохтоне биљке). Потврђени су стари или непоуздани наводи за три аутохтоне и једну алохтону биљку у флори Србије. Осам биљних таксона представљају новину за ужу Србију, Војводину или Косово и Метохију, а за три биљке је доказано присуство у одређеним административним јединицама у Србији. Последњи део рада садржи информације о осам таксона чије је присуство у Србији или у њеним територијалним јединицама оповргнуто. 